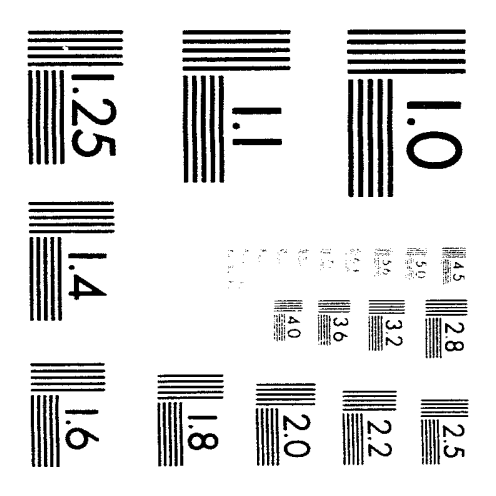



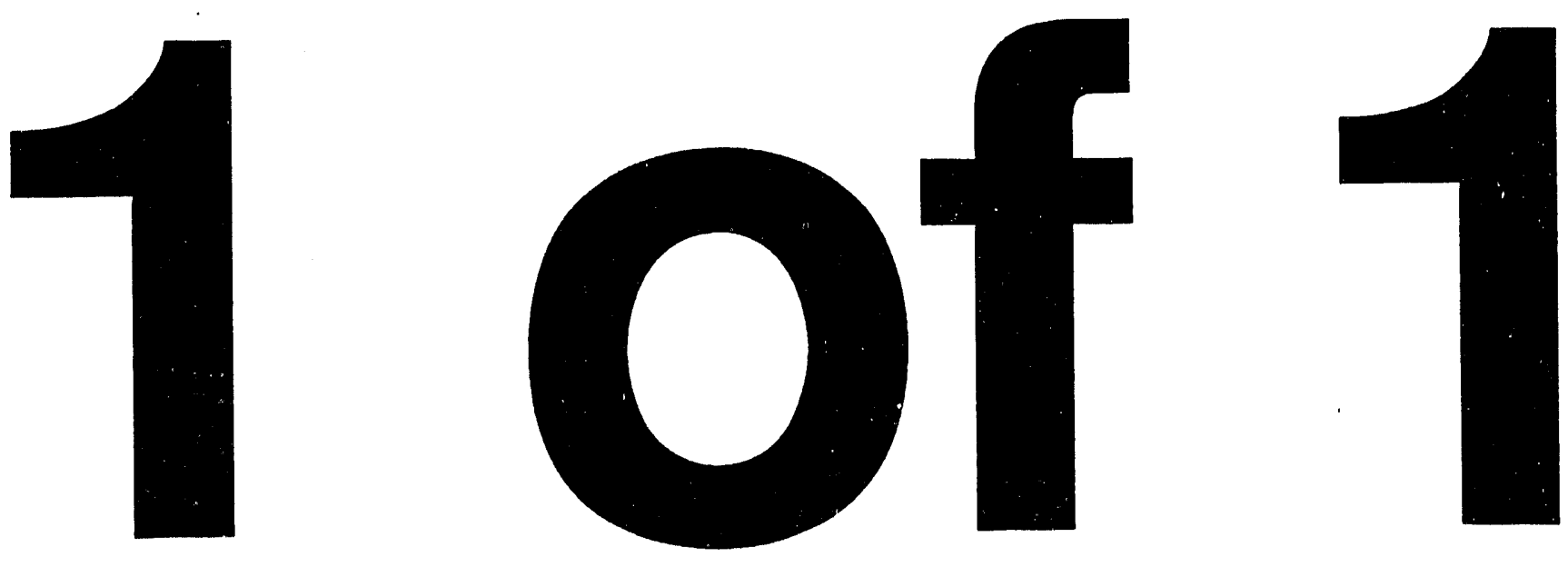
WSRC-TR-92-251

\section{COMPLIANCE REVIEW FOR THE UNH STORAGE TANK (U)}

by J.M. Low

Westinghouse Savannah River Company

Savannah River Site

Aiken, South Carolina 29808

This paper was prepared in connection with work done under Contract No. DE-AC09-89SR18035 with the U. S. Department of Energy. By acceptance of this paper, the publisher and/or recipient acknowledges the U.S. Government's right to retain a nonexclusive, royalty-free license in and to any copyright covering this paper, along with the right to reproduce and to authorize others to reproduce all or part of the copyrighted paper. 


\section{DISCLAIMER}

This report was prepared as an account of work sponsored by an agency of the United States Government. Neither the United States Government nor any agency thereof, nor any of their employees, makes any warranty, express or implied, or assumes any legal liability or responsibility for the accuracy, completeness, or usefulness of any information, apparatus, product, or process disclosed, or represents that its use would not infringe privately owned rights. Reference herein to any specific commercial product, process, or service by trade name, trademark, manufacturer, or otherwise does not necessarily constitute or imply its endorsement, recommendation, or favoring by the United States Government or any agency thereof. The views and opinions of authors expressed herein do not necessarily state or reflect those of the United States Government or any agency thereof.

This replort has been reproduced directly from the best available copy.

Available to DOE and DOE contractors from the Office of Scientific and Technical Information, P. O. Box 62, Oak Ridge, TN 37831; prices available from (615) 576-8401.

Available to the public from the National Technical Information Service, U. S. Department of Commerce, 5285 Port Royal Rd., Springfield, VA 22161 


\section{$W($ Aow 1.80) \\ WESTINGHOUSE SAVANNAH RIVER COMPANY INTER-OFFICE MEMORANDUM}

WSRC-TR-92-251

May 19, 1992

TO: W.L. Williams, 707-H

Manager, Project 4257, UN Storage Tank Does Nor CONTAN UNCLASBFIED CONTAOLLED NUCLEAR INFOAMATION

EROM: J.M. LOW, $992 W-1 \bigcirc \times$ L

Separations Analy\$is, NPSR

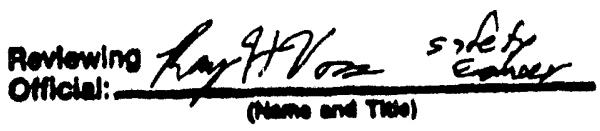

Compliance Review For The UNH Stordge-Tank (u)

INTRODUCTION :

The purpose of Project S-4257, USE-UNH 150,000 Gallon Storage Tank, is to provide interim storage for the liquid uranyl nitrate (UNH) product from H-Canyon until the UNH can be processed in the new Uranium Solidification Facility (Project S-2052). NPSR was requested by Project Management and DOE-SR to perform a design compliance review for the UNH Storage Tank to support the Operational Readiness Review (ORR) and the Operational Readiness Evaluation (ORE), respectively. The project was reviewed against the design criteria contained in the DOE Order 6430.1A, General Design Criteria. This report documents the results of the compliance review.

SUMMARY :

Project information was reviewed against applicable design criteria contained in the DOE Order 6430.1A, General Design criteria. The review, documented in this report, demonstrates that the design and construction of the UNH Storage Tank are in compliance with the General Design Criteria (i.e. no applicable design criteria were identified as non-compliances).

\section{DISCUSSION :}

Design information was collected and reviewed to provide the information necessary to select applicable design criteria from DOE Order 6430.1A, General Design Criteria. Design information included, but was not limited to the following: 
1) Basic Design Report

2) Design Specifications

3) the Safety Analysis Report

4) Technical Baseline Documentation

5) Project Drawings

6) Project Files

7) Operating and Emergency Procedures

8) Du Pont Engineering Design Standards

9) Site Specifications

10) Related Correspondence

The UNH Storage Tank was divided into the following areas for review against the design criteria provided in the General Design Criteria; the tank and support structure, associated piping into and out of H-Canyon, auxilary systems electrical power supplies, electrical control circuits, and instrumentation (i.e. sensors, detectors, indicators, alarm units, etc.).

The results of the compliance review are summarized in tabular form. The table includes the following information: the section number, the design criterion, the status (compliance or non-compliance), additional comments, and references. The review, documented in this report, demonstrates that the design and construction of the UNH Storage Tank are in compliance with the DOE Order 6430.1A, General Design Criteria 
EU-S Tank, DOE 6430.1A Design Compliance Review Page 3 of 52

\begin{tabular}{|c|c|c|c|c|}
\hline $\begin{array}{l}\text { DOE } 6430.1 \mathrm{~A} \\
\text { Section }\end{array}$ & DOE 6430.1A Design Criterion & STATUS & Comment & Reference \\
\hline $\begin{array}{l}0110 \\
0110-5 \\
0110-52\end{array}$ & 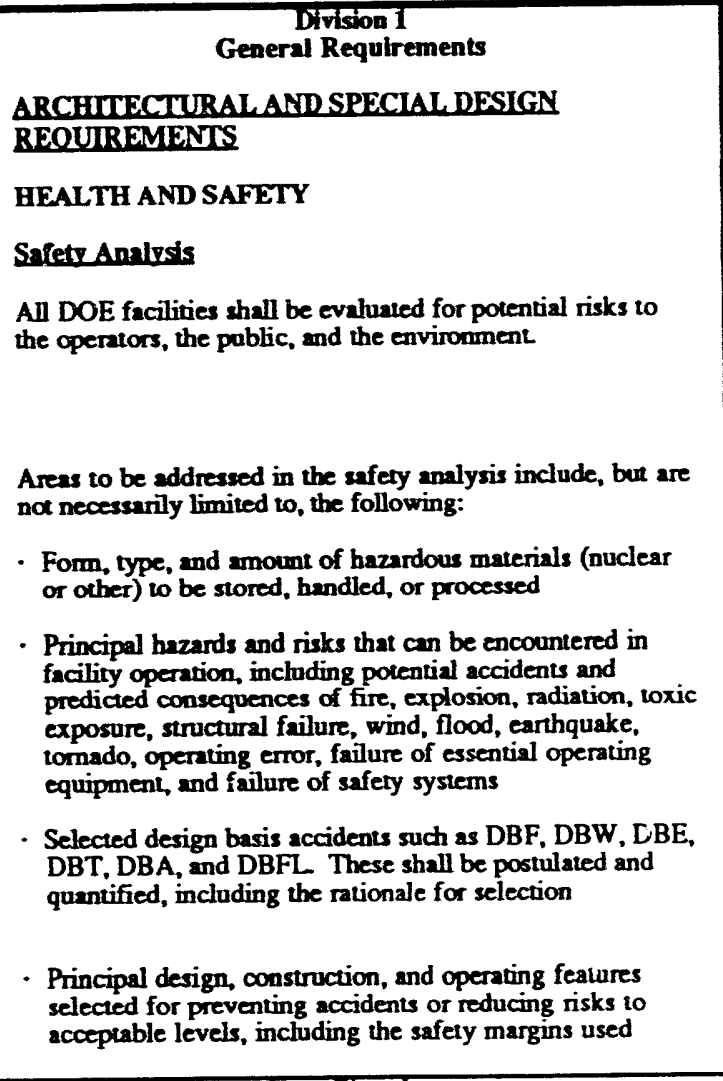 & C & $\begin{array}{l}\text { A safety evaluation of the EU-S tank is included } \\
\text { in Saffery Analysis Report (SAR) } \\
\text { DPSTSA-200-10. SUPP } 11 \text {. This report } \\
\text { addresses risk to operators, the public and the } \\
\text { environment. } \\
\text { Uranyl nitrate hexahydrate (UNH) is discussed } \\
\text { in terns of form, type snd quantity in the SAR. } \\
\text { Principal hazards and their associated risks are } \\
\text { evaluated in the SAR. } \\
\text { Frequencies of occurrence along with } \\
\text { consequence have been evaluated to determine } \\
\text { associated risk. Risks of potentiai accidents are } \\
\text { listed in SAR. } \\
\text { Design basis accidents are selected and } \\
\text { quantified in SAR Rationale for their selection is } \\
\text { included. } \\
\text { Facility design, construction and operating } \\
\text { features that prevent or mitigate accident } \\
\text { consequences are included in DPSTSA-200-10, } \\
\text { SUPP 11. }\end{array}$ & Ref. 1 \\
\hline $0110-5.3$ & $\begin{array}{l}\text { Emereencr Preparedness Planning } \\
\text { Exch facility that has potential on-site or off-site effects } \\
\text { during normal or abnomal operations shall have an } \\
\text { Emergency Plan prepared which shall be incorporated with } \\
\text { the Site Emergency Preparedness Plan. }\end{array}$ & C & $\begin{array}{l}\text { Emergencies involving the EU-S tank will be } \\
\text { managed with the existing facility emergency } \\
\text { procedure. }\end{array}$ & $\begin{array}{l}\text { Ref. } 2 \\
\text { Ref. } 3 \\
\text { Ref. } 4\end{array}$ \\
\hline
\end{tabular}


EU-S Tank, DOE 6430.1A Design Compliance Review Page 4 of 52

\begin{tabular}{|c|c|c|c|c|}
\hline $\begin{array}{c}\text { DOE } 6430.1 A \\
\text { Section }\end{array}$ & DOE 6430.1A Design Criterion & STATUS & Comment & Reference \\
\hline $\begin{array}{l}0110-6 \\
0110-6.1\end{array}$ & $\begin{array}{l}\text { FIREPROTIECTION } \\
\text { General } \\
\text { Facilities shall comply with the following: } \\
\text { - DOE } 5480.4 \text { Autachment 2, Section } 2 C \\
\text { : NFPA Codes } \\
\text { - VL Product Directories } \\
\text { - DOE } 5480.7\end{array}$ & C & $\begin{array}{l}\text { National Fire Protection Association (NFPA) } \\
\text { codes and Underwriters Laboratory (UL) } \\
\text { standards are referenced throughout site } \\
\text { specifications, engineering standards and design } \\
\text { standards. }\end{array}$ & Ref. 5 \\
\hline OHIO-7 & $\begin{array}{l}\text { ENVIRONMENTAL PROTECTIONANDPOCLOTION } \\
\text { CONTROL } \\
\text { The construcion of all DOE facilities shall comply with the } \\
\text { environmental protection and pollution control portions of } \\
\text { the following: } \\
\text { - DOE 4700.1. Chapter V } \\
\text { - DOE } 5480.4 \\
\text { - DOE } 5480.1 B \\
\text { DOE } 5440.1 \text { ( } 5440.1 \mathrm{D})\end{array}$ & c & $\begin{array}{l}\text { A National Environmental Protection Act } \\
\text { (NEPA) environment evaluation and National } \\
\text { Emissions Standards for Hazardous Air Pollutants } \\
\text { (NESHAP) permin review were perfomed. } \\
\text { These reviews show the EU-S rank can be } \\
\text { operated without any adverse environmentai } \\
\text { impact. }\end{array}$ & $\begin{array}{l}\text { Ref. } 8 \\
\text { Ref. } 9\end{array}$ \\
\hline
\end{tabular}




\begin{tabular}{|c|c|c|c|c|}
\hline $\begin{array}{l}\text { DOE 6430.1A } \\
\text { Section }\end{array}$ & DOE 6430.1A Design Criterion & STATUS & Comment & Reference \\
\hline $0110-9$ & $\begin{array}{l}\text { OPERAMON, MAINTIUNANCE, REPAIR, AND } \\
\text { REPLACEMENT } \\
\text { Planning and design of buildings and other structures, } \\
\text { including their operating components and systems, shall take } \\
\text { into account all aspects of operation and maintenance } \\
\text { inchuding: } \\
\text { - Equipment accessibility } \\
\text { - Dismantling } \\
\text { - Replacement } \\
\text { - Repair } \\
\text { - Frequency of preventive maintenance } \\
\text { - Inspection requirements } \\
\text { - Persomnel safety } \\
\text { - Day-to-day operation }\end{array}$ & C & $\begin{array}{l}\text { The listed aspects of operation and maintenance } \\
\text { have been considered in the planning and } \\
\text { designing of the EU-S tank and discussed in the } \\
\text { following documents: } \\
\text { - Basic Data Report \#88-17, Rev. } 2 \\
\text { - Specification 2-246020 } \\
\text { - Design Process Hazards Review } 8244505-1 \\
\text { - Operational Safery Requirements, Uranyl } \\
\text { Nitrate Storage Facility }\end{array}$ & $\begin{array}{l}\text { Ref. } 10 \\
\text { Ref. } 11 \\
\text { Ref. } 12 \\
\text { Ref. } 13\end{array}$ \\
\hline $\begin{array}{l}\text { 0110-13 } \\
0110-13.2 \\
0110-13.21\end{array}$ & $\begin{array}{l}\text { PHYSICALPROTECTION } \\
\text { Access Control and Security Areas } \\
\text { General } \\
\text { Security areas shall be established when the nature, size. } \\
\text { revealing chancteristics, sensitiviny, or importance of } \\
\text { classified matter or associated security interests is such that } \\
\text { access to them cannot be effectively controlled by other } \\
\text { internal measures. The type of security area established } \\
\text { depends on the nature of the security interests to be } \\
\text { protected, with following types required for the protection } \\
\text { of the listed security interests: } \\
\text { Protected Area to control Category I and II quantities of } \\
\text { special nuclear material }\end{array}$ & C & $\begin{array}{l}\text { The EU-S tank contains Category II quantities of } \\
\text { Special Nuclear Material (SNM) in accordance } \\
\text { with criteria of DOE Order S632.2A. The tank is } \\
\text { constructed within the H-Area limited area. } \\
\text { Projec S-2891 is intended to bring the UNH tank } \\
\text { into compliance. A Tempory Security Plan, TSP- } \\
90 / 0403-2-H-04-013 \text {, to allow operation of the } \\
\text { tank in limited area unil security upgrades are } \\
\text { accomplished has been approved by WSRC. } \\
\text { This plan is based on the graded safegards } \\
\text { conceph and is in compliance with the site CSA } \\
\text { (WSRC-RP-90-12) for DOE Order } 5632.2 \text {. }\end{array}$ & Ref. 14 \\
\hline
\end{tabular}




\begin{tabular}{|c|c|c|c|c|}
\hline $\begin{array}{l}\text { DOE } 6430.1 A \\
\text { Section }\end{array}$ & DOE 6430.1A Design Criterion & STATUS & Comment & Reference \\
\hline \multirow[t]{3}{*}{$\begin{array}{l}0110-99 \\
0110-99.0 \\
0110-99.0 .1\end{array}$} & $\begin{array}{l}\text { SPECIALFACILTriES } \\
\text { Nenrenctor Ninclear Faclities-General } \\
\text { General } \\
\text { The type and level of hazard shall be determined for each } \\
\text { functional area of the special facility, the anendant degree } \\
\text { of risk established, and the possibility of cross-contamination } \\
\text { considered. }\end{array}$ & C & $\begin{array}{l}\text { Hazards associated with the EU-S tank have } \\
\text { been determined and reviewed in the following } \\
\text { Process Hazard Reviews (PHRs): } \\
\text { - PHR 200-H-437 } \\
\text { - UE\&C 8244505-1 } \\
\text { - WSRC-PH-90-104 } \\
\text { The risk associated with selected hazards are } \\
\text { evaluated in DPSTSA-200-10, SUPP } 11 \text {. }\end{array}$ & $\begin{array}{l}\text { Ref. } 1 \\
\text { Ref. } 12 \\
\text { Ref. } 15 \\
\text { Ref. } 16\end{array}$ \\
\hline & $\begin{array}{l}\text { Radioactive and hazandous materials (chemicals, feed } \\
\text { wastes, etc) shall be segregated from each other to } \\
\text { minimize the generation of mixed waste. }\end{array}$ & C & $\begin{array}{l}\text { UNH contained in EUS tank is segregated from } \\
\text { other hazardous materials used in } 211-\mathrm{H} \text {. Nitric } \\
\text { acid and water are the only service lines tied into } \\
\text { the EU-S tank. }\end{array}$ & Ref. I \\
\hline & $\begin{array}{l}\text { In addition, areas where radioactive materials are used } \\
\text { ihall be designed for case of decontamination during } \\
\text { building usage and also for decommissioning after the } \\
\text { building life cycle. }\end{array}$ & $\bar{C}$ & $\begin{array}{l}\text { Contamination control and ease of } \\
\text { decomamination during tank life were } \\
\text { incorporated into tank design. The tank and } \\
\text { associated piping are constructed of stainless } \\
\text { steel to limit corrosion. An enclosed sample } \\
\text { station drains any spillage back to the tank. The } \\
\text { tank is surrounded by a curbed area which drains } \\
\text { to a pumpable sump. Strinless steel construction, } \\
\text { drairable piping and placement of High } \\
\text { Efficiency Particulate Air (HEPA) fliters will } \\
\text { ease decommissioning of the tank. A } \\
\text { decommissioning plan will be developed for EU- } \\
S \text { tank before shurdown. }\end{array}$ & $\begin{array}{l}\text { Ref. } 1 \\
\text { Ref. } 10 \\
\text { Ref. } 11 \\
\text { Ref. } 38 \\
\text { Ref. } 39\end{array}$ \\
\hline $0110-99.0 .4$ & $\begin{array}{l}\text { Building Layout } \\
\text { The design of the facility shall include controlled access to } \\
\text { areas of potential hazards within the facility. }\end{array}$ & C & $\begin{array}{l}\text { The EU-S tank is located inside the H-Area } \\
\text { limited area, which limits acoess to those } \\
\text { personnel authorized to enter the area. The tank } \\
\text { is also located inside the A-line Radiologically } \\
\text { Controlled Area (RCA) boundary. Entry to the } \\
\text { RCA is controlled by Health Protection personnel } \\
\text { and procedures. }\end{array}$ & $\begin{array}{l}\text { Ref. } 1 \\
\text { Ref. } 14\end{array}$ \\
\hline
\end{tabular}




\begin{tabular}{|c|c|c|c|c|}
\hline $\begin{array}{c}\text { DOE } 6430.1 \mathrm{~A} \\
\text { Section }\end{array}$ & DOE 6430.1A Design Criterion & STATUS & Comment & Reference \\
\hline \multirow[t]{2}{*}{$\begin{array}{l}\text { Jiro-s9.0.4 } \\
\text { (continued) }\end{array}$} & 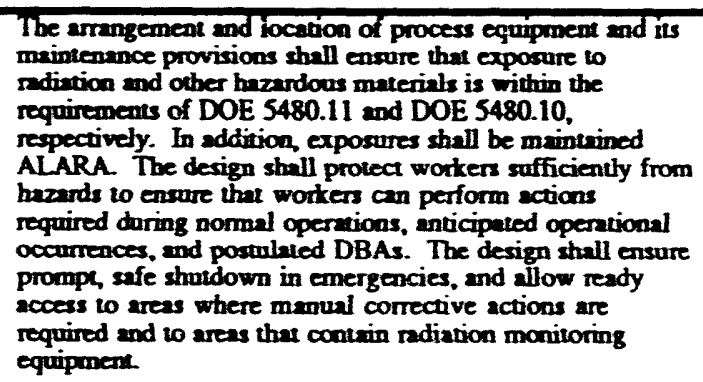 & $\mathrm{C}$ & 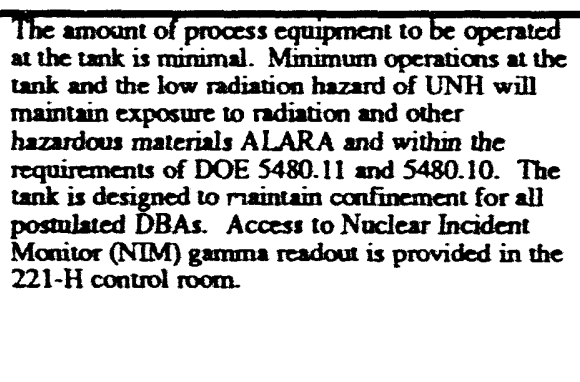 & $\begin{array}{l}\text { Ref. } \\
\text { Ref. } 10 \\
\text { Ref. } 37\end{array}$ \\
\hline & 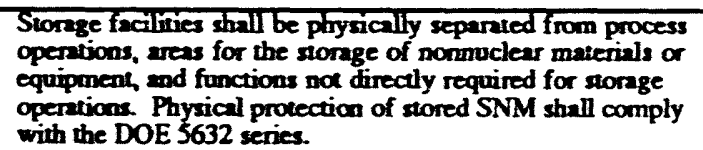 & $c$ & $\begin{array}{l}\text { The EU-S tank is physically scparated from the } \\
\text { USF and H-Canyon and the 211-H chemical } \\
\text { storge facility. A Safeguards and Security Plan } \\
\text { and Material Accountability and Control Plan } \\
\text { have been genereted ard approved by DOE. }\end{array}$ & $\begin{array}{l}\text { Ref. } \\
\text { Ref. } 14 \\
\text { Ref. } 17\end{array}$ \\
\hline $0110-99.0 .8$ & 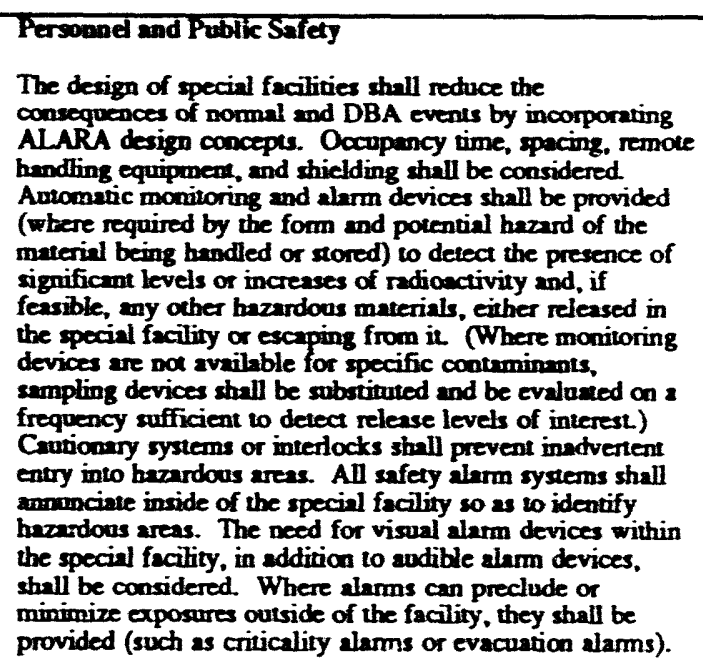 & C & 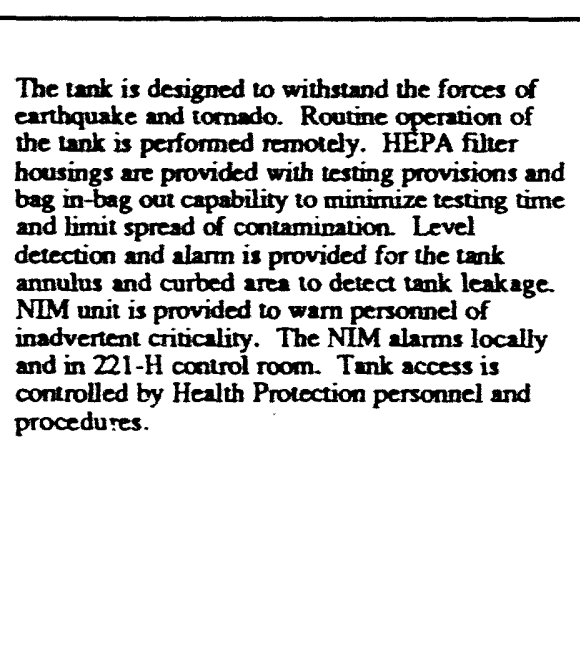 & $\begin{array}{l}\text { Ref. } 1 \\
\text { Ref. } 10 \\
\text { Ref. } 11 \\
\text { Ref. } 35\end{array}$ \\
\hline
\end{tabular}




\begin{tabular}{|c|c|c|c|c|}
\hline $\begin{array}{l}\text { DOE 6430.1A } \\
\text { Section }\end{array}$ & DOE 6430.1A Design Criterion & STATUS & Comment & Reference \\
\hline $\begin{array}{l}\text { Oino-9958s } \\
\text { (conthued) }\end{array}$ & 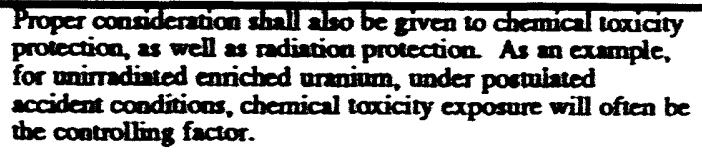 & $c$ & $\begin{array}{l}\text { The EUS tank will be operated under the } \\
\text { requirements of the existing } 211 \text {-H Induatrial } \\
\text { Hygiene Program and sile documents DPSOP } 40 \text { - } \\
5 \text { and WSRC 8Q. }\end{array}$ & $\begin{array}{l}\text { Ref. } 18 \\
\text { Ref. } 19\end{array}$ \\
\hline $\begin{array}{l}0111 \\
0111-1\end{array}$ & 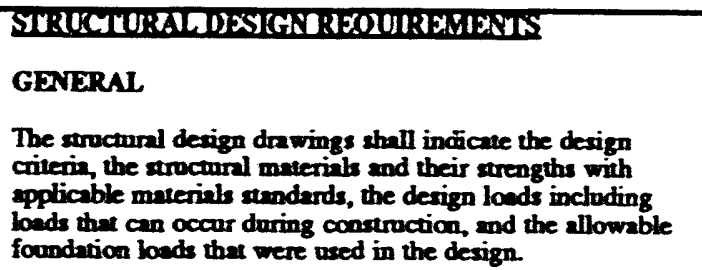 & C & $\begin{array}{l}\text { Structural drawings include design criteria, } \\
\text { materials, standards and foundation design loads. }\end{array}$ & Ref. 20 \\
\hline & $\begin{array}{l}\text { Where earthgualce resistance is required, the cognizant } \\
\text { DOE sumbority should consul LBL-9143 for practical } \\
\text { guidelines for engineering earthquake safety and } \\
\text { management planning and technical procedures for design } \\
\text { of new facilines or evaluation of existing cores. This } \\
\text { documemt provides a process for a cost-effective plan } \\
\text { chect or third-party review of the design approach. }\end{array}$ & $C$ & $\begin{array}{l}\text { Third-party review was performed by the U.S. } \\
\text { Army Corps of Engineers. }\end{array}$ & \\
\hline $\begin{array}{l}\text { 0111-2 } \\
0111-2.1\end{array}$ & $\begin{array}{l}\text { LOAWS } \\
\text { Genernl Requirements } \\
\text { Structures und their elements shall be designed for the loads } \\
\text { prescribed in these criteria. }\end{array}$ & C & $\begin{array}{l}\text { A review of the EU-S tonk design against Section } \\
\text { 0111. "Structural Design Requirements," was } \\
\text { performed by Army Corps of Engineers. It was } \\
\text { determined that design of EUS tank } \\
\text { incorporated the requirements of DOE Order } \\
\text { 6430.1A. }\end{array}$ & $\begin{array}{l}\text { Ref. } 21 \\
\text { Ref. } 22\end{array}$ \\
\hline $\begin{array}{l}0111-23 \\
0111-2.2 .1\end{array}$ & $\begin{array}{l}\text { Dendloads } \\
\text { General } \\
\text { Dead loads shall include the weights of all permanent } \\
\text { malerials and oquipment, including the structuris own } \\
\text { weight, supponted in, or on, a structure. Loed calculations } \\
\text { shall include an allowance foc any loadings snticipated to be } \\
\text { added al a later date. Initially assumed loads shall be } \\
\text { reviewed so that the final design reflects the configuration } \\
\text { shown on the drawings. }\end{array}$ & C & $\begin{array}{l}\text { See comment at 0111-21, "General," concerning } \\
\text { Army Corps of Engineers review. }\end{array}$ & $\begin{array}{l}\text { Ref. } 21 \\
\text { Ref. } 22\end{array}$ \\
\hline
\end{tabular}




\begin{tabular}{|c|c|c|c|c|}
\hline $\begin{array}{l}\text { DOE 6430.1A } \\
\text { Sectlon }\end{array}$ & DOE 6430.1A Design Criterion & STATUS & Comment & Reference \\
\hline JIII-22.2 & 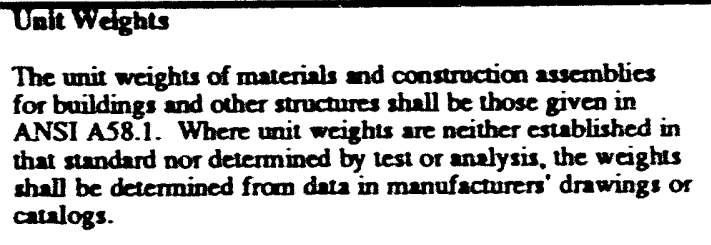 & C & $\begin{array}{l}\text { See comment at 0111-2.1. "Genend," concerning } \\
\text { Army Corps of Engineers review. }\end{array}$ & $\begin{array}{l}\text { Ref. } 21 \\
\text { Ref. } 22\end{array}$ \\
\hline $0111-2.23$ & $\begin{array}{l}\text { Service Equipment } \\
\text { Desigg dead loads shall include the weight of all permanent } \\
\text { service equipment. }\end{array}$ & c & $\begin{array}{l}\text { See comment at } 0111-2.1 \text {. "General," conceming } \\
\text { Army Corps of Engineers review. }\end{array}$ & $\begin{array}{l}\text { Ref. } 21 \\
\text { Ref. } 2\end{array}$ \\
\hline $\begin{array}{l}0111-23 \\
0111-23.1\end{array}$ & 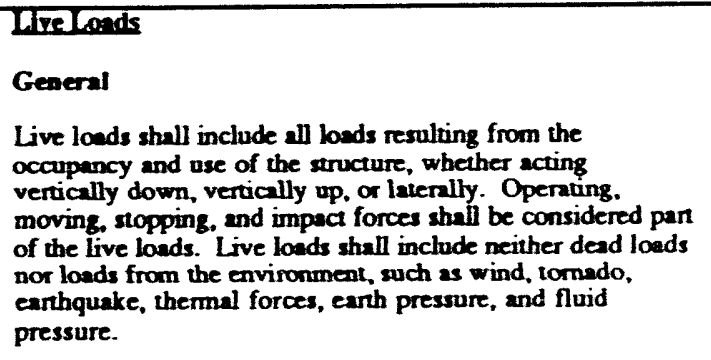 & c & $\begin{array}{l}\text { See comment at 0111-21. "General," conceming } \\
\text { Army Corps of Engineers review. }\end{array}$ & $\begin{array}{l}\text { Ref. } 21 \\
\text { Ref. } 22\end{array}$ \\
\hline $0111-232$ & $\begin{array}{l}\text { Buildthgs and Other Structures } \\
\text { Live loads for huildings and ocher struaures shall be those } \\
\text { produced by the intended use or occupency. } \\
\text { In no case shall they be less than the minimum uniform load } \\
\text { or concentrated load stipulated in ANSI AS8.1. }\end{array}$ & c & $\begin{array}{l}\text { See comment at 0111-21. "General." concerning } \\
\text { Army Corps of Engineers review. }\end{array}$ & $\begin{array}{l}\text { Ref. } 21 \\
\text { Ref. } 22\end{array}$ \\
\hline & $\begin{array}{l}\text { Live loads on roofis thall be as stipulated in ANSIAS8.1. } \\
\text { They shall include the minimum roof live loads or the snow } \\
\text { loads and snow drifts or possible rain loads stipulated } \\
\text { therein. whichever produces the more severe effect. }\end{array}$ & c & $\begin{array}{l}\text { See comment at oIII-2I, "General," concerming } \\
\text { Army Corps of Engineers review. }\end{array}$ & $\begin{array}{l}\text { Ref.21 } \\
\text { Ref. } 22\end{array}$ \\
\hline
\end{tabular}




\begin{tabular}{|c|c|c|c|c|}
\hline $\begin{array}{c}\text { DOE 6430.1A } \\
\text { Section }\end{array}$ & DOE 6430.1A Design Criterion & STATUS & Comment & Reference \\
\hline $\begin{array}{l}0111-2.4 \\
0111-2.4 .1\end{array}$ & $\begin{array}{l}\text { Whindoads } \\
\text { General } \\
\text { The structural frame and exterior components of all } \\
\text { buildings, signs, tanks, wowers, and oher exposed structures } \\
\text { shall be designed to resist pressures due to wind assumed to } \\
\text { act from any direction. Partial wind loading shall be } \\
\text { considered if it produces a more severe effect. }\end{array}$ & C & $\begin{array}{l}\text { See comment at 0111-2.1, "General," conceming } \\
\text { Army Corps of Engineers review. }\end{array}$ & $\begin{array}{l}\text { Ref. } 21 \\
\text { Ref. } 22\end{array}$ \\
\hline $0111-2.42$ & $\begin{array}{l}\text { Buildings and Other Structures } \\
\text { Wind load design for buildings and other structures shall be } \\
\text { determined in accordance with procedures in ANSI A58.1 } \\
\text { with the basic wind speed being obtained from UCRL } \\
15910 \text {. }\end{array}$ & C & $\begin{array}{l}\text { See comment at 0111-2.1, "General," conceming } \\
\text { Army Corps of Engineers review. }\end{array}$ & $\begin{array}{l}\text { Ref. } 21 \\
\text { Ref. } 22\end{array}$ \\
\hline & $\begin{array}{l}\text { The basic wind speed shall be derived from DOE site- } \\
\text { specific hazard model studies summanized in UCRL 53526, } \\
\text { Rev. } 1 \text { (available at DOE Field Offices or from the Office } \\
\text { of Nuclear Safety, DOE Headquarters). If site-specific } \\
\text { hazard model studies are not available, a hazard model shall } \\
\text { be developed that is consistent with the approach used in } \\
\text { UCRL 53526, Rev. } 1 \text {. } \\
\text { The basic wind speeds for any specific site shall be } \\
\text { determined following the procedures in UCRL } 15910 \text {, } \\
\text { except that Exposure "C" should be used for all construction } \\
\text { unless it can be shown that the necessary permanent } \\
\text { shielding will be provided by natural terrain (not including } \\
\text { shielding from trees or adjacent buildings). } \\
\text { To determine the design wind loads, all factors and } \\
\text { coefficients stipulated in ANSI A58.1 shall be applied to the } \\
\text { site-specific basic wind speeds. }\end{array}$ & $C$ & $\begin{array}{l}\text { See comment at 0III-2.1, "General," conceming } \\
\text { Army Corps of Engineers review. }\end{array}$ & $\begin{array}{l}\text { Ref. } 21 \\
\text { Ref. } 22\end{array}$ \\
\hline 711.2.5 & $\begin{array}{l}\text { Tornado Loads } \\
\text { The basic wind speed and missile parameters shall be } \\
\text { derived from DOE site-specific hazard model studies } \\
\text { summarized in UCRL 53526, Rev. 1. If site specific hazard } \\
\text { model studies are not available, a hazard model shall be } \\
\text { developed consistent with the approach used in UCRL } \\
53526, \text { Rev. } 1 \text {. }\end{array}$ & C & $\begin{array}{l}\text { See comment at 0111-2.1, "General," concerning } \\
\text { Army Corps of Engineers review. }\end{array}$ & $\begin{array}{l}\text { Ref. } 21 \\
\text { Ref. } 22\end{array}$ \\
\hline
\end{tabular}




\begin{tabular}{|c|c|c|c|c|}
\hline $\begin{array}{l}\text { DOE } 6430.1 A \\
\text { Section }\end{array}$ & Design Criterion & STATUS & Comment & Reference \\
\hline $\begin{array}{l}\text { Ji11-25 } \\
\text { (continued) }\end{array}$ & $\begin{array}{l}\text { Facilties for radioactive malerial handling, processing, or } \\
\text { storage, and other facilities having high value or vital } \\
\text { importance to DOE programs that are classified as critical } \\
\text { facilities, shall require special tomado loading criteria as } \\
\text { stipulated in Section } 0111-99.0 \text {. Nonreactor Nuclear } \\
\text { Facilities--General. }\end{array}$ & & & \\
\hline \multirow[t]{3}{*}{$\begin{array}{l}0111-2.7 \\
0111-2.7 .1\end{array}$} & 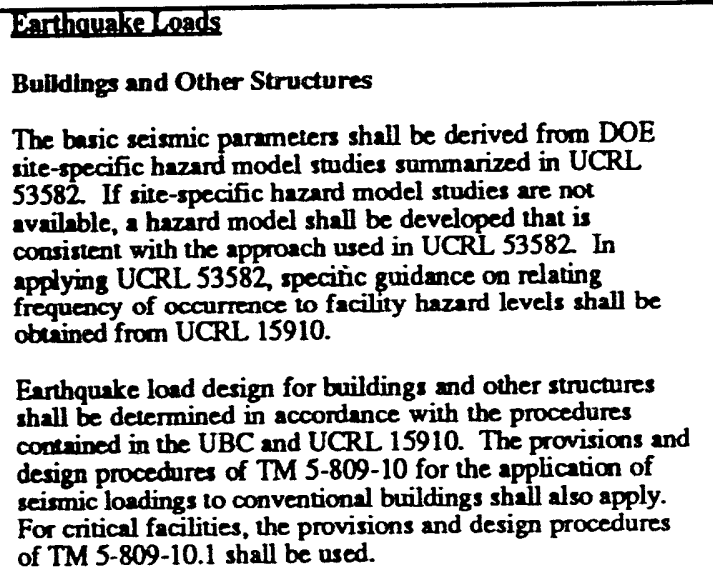 & C & $\begin{array}{l}\text { See comment at 0111-2.1, "General," concerning } \\
\text { Army Corps of Engineers review. }\end{array}$ & $\begin{array}{l}\text { Ref. } 21 \\
\text { Ref. } 22\end{array}$ \\
\hline & $\begin{array}{l}\text { Facilities for radioactive materal handling, processing, or } \\
\text { storage, and other facilities having high value or vital } \\
\text { importance to DOE programs that are classified as critical } \\
\text { facilities, shall require application of dynamic analysis in } \\
\text { ietermining structural requirements for earthquake loading } \\
\text { as stipulated in Section } 0111-99.0 \text {. Nonreactor Nuclear } \\
\text { Facilities-General. }\end{array}$ & $C$ & $\begin{array}{l}\text { See comment at ol11-2.1, "General," conceming } \\
\text { Amy Corps of Engineers review. }\end{array}$ & $\begin{array}{l}\text { Ref. } 21 \\
\text { Ref. } 22\end{array}$ \\
\hline & $\begin{array}{l}\text { An independent review of the seismic design shall be made } \\
\text { for facilities and buildings where a seismic event can have a } \\
\text { potential risk to operator lives, to public safety, or of large } \\
\text { economic loss. The review shall be made in two stages, the } \\
\text { first at the end of preliminary design and the second before } \\
\text { final design is complete. For additional guidance on } \\
\text { independent reviews, see LBL- } 9143 \text { and UCRL } 15910 \text {. }\end{array}$ & $\mathrm{C}$ & $\begin{array}{l}\text { An independent review of the EU-S tank seismic } \\
\text { design was performed by the Amny Corps of } \\
\text { Engineers. }\end{array}$ & $\begin{array}{l}\text { Ref. } 21 \\
\text { Ref. } 22\end{array}$ \\
\hline
\end{tabular}


EU-S Tank, DOE 6430.1A Design Compliance Review Page 12 of 52

\begin{tabular}{|c|c|c|c|c|}
\hline $\begin{array}{l}\text { DOE 6430.1A } \\
\text { Section }\end{array}$ & DOE 6430.1A Design Criterion & STATUS & Comment & Reference \\
\hline $\begin{array}{l}0111-2.8 \\
0111-2.8 .1\end{array}$ & 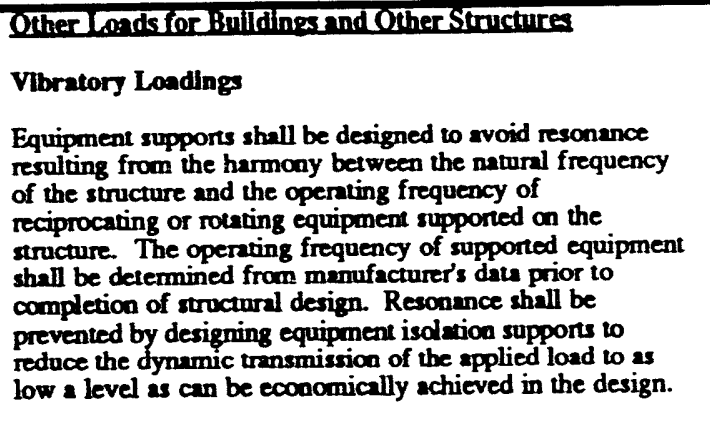 & C & $\begin{array}{l}\text { See comment at 0111-2.1, "General," conceming } \\
\text { Army Corps of Engineers review. }\end{array}$ & $\begin{array}{l}\text { Ref. } 21 \\
\text { Ref. } 22\end{array}$ \\
\hline $0111-283$ & $\begin{array}{l}\text { Figld and Gas Pressures } \\
\text { The design of components of buildings and other structures } \\
\text { shall include the effects of fluid and gas pressures, both } \\
\text { intemal and extemal. }\end{array}$ & C & $\begin{array}{l}\text { See comment at 0111-2.1. "General." conceming } \\
\text { Amy Corps of Engineers review. }\end{array}$ & $\begin{array}{l}\text { Ref. } 21 \\
\text { Ref. } 22\end{array}$ \\
\hline OIII.2.8.4 & $\begin{array}{l}\text { Thermal Forces } \\
\text { The design of structures shall include the effecas of stresses } \\
\text { and movements resulting from variations in temperature. } \\
\text { The rise and fall in the etemperture shall be determined for } \\
\text { the localities in which the siructures are to be built } \\
\text { Sructures shall be designed for movements resulting from } \\
\text { the maximum seasonal temperature change. The design } \\
\text { shall provide for the lags between air temperatures and the } \\
\text { interior temperatures of massive concrete members or } \\
\text { structures. }\end{array}$ & C & $\begin{array}{l}\text { See comment at 0111-2.1, "General," conceming } \\
\text { Ammy Corps of Engineers review. }\end{array}$ & $\begin{array}{l}\text { Ref. } 21 \\
\text { Ref. } 22\end{array}$ \\
\hline $0111-2.85$ & $\begin{array}{l}\text { Creep and Shrinkage forces } \\
\text { Concrete and masonry structures shall be investigated for } \\
\text { stresses and deformations induced by creep and shrinkage. } \\
\text { For concrete and mascory structures, the minimum linear } \\
\text { coefficient of shrinkage shall be assumed to be } 0.0002 \\
\text { inchinch, unless a devailied analysis is undertaken. the } \\
\text { heoretical shrinkage displacement shall be computed as the } \\
\text { product of the linear coefficient and the length of the } \\
\text { member. }\end{array}$ & C & $\begin{array}{l}\text { See comment at 0111-2.1. "General," conceming } \\
\text { Army Corps of Engineers review. }\end{array}$ & $\begin{array}{l}\text { Ref. } 21 \\
\text { Ref. } 22\end{array}$ \\
\hline
\end{tabular}


EU-S Tank, DOE 6430.1A Design Compliance Review Page 13 of 52

\begin{tabular}{|c|c|c|c|c|}
\hline $\begin{array}{l}\text { DOE } 6430.1 A \\
\text { Section }\end{array}$ & DOE 6430.1A Design Criterion & STATUS & Comment & Reference \\
\hline 0171-2.10 & 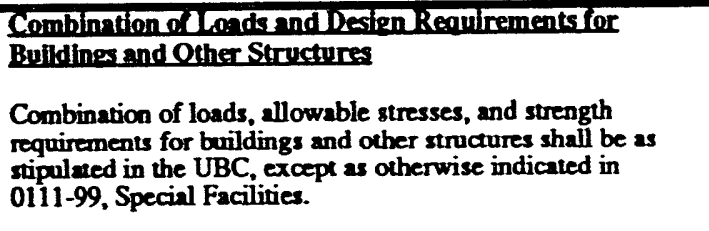 & C & $\begin{array}{l}\text { See comment at 0111-2.1, "General." conceming } \\
\text { Army Corps of Engineers review. }\end{array}$ & $\begin{array}{l}\text { Ref. } 21 \\
\text { Ref. } 22\end{array}$ \\
\hline $\begin{array}{l}\text { 0111-3.4 } \\
0111-3.4 .1\end{array}$ & $\begin{array}{l}\text { Eaundrtions } \\
\text { General Requirements } \\
\text { The provisions of the UBC shall be the minimum } \\
\text { regurrements for foumdations design. The potential adverse } \\
\text { effects of frost heave and movements due to expansive soils } \\
\text { shall also be considered in the design. } \\
\text { For all structures, Section } 0201 \text {. Subburface Investigations. } \\
\text { shall be complied with to determine subsurface conditions. } \\
\text { recommended foundation type, allowable design soil } \\
\text { bearing pressure, seismic potentiall, and differential } \\
\text { seallement. }\end{array}$ & c & $\begin{array}{l}\text { See comment at 0111-2.1, "General," conceming } \\
\text { Amy Corps of Engineers review. }\end{array}$ & $\begin{array}{l}\text { Ref. } 21 \\
\text { Ref. } 22\end{array}$ \\
\hline $\begin{array}{l}\text { 011-99 } \\
0111-99.0 \\
0111-99.0 .1\end{array}$ & 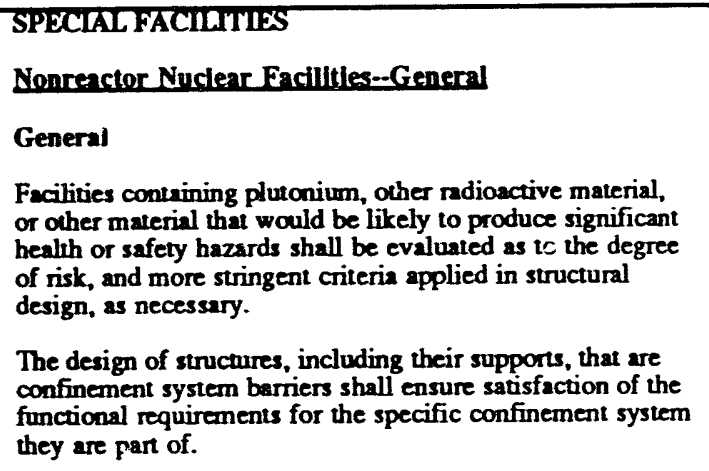 & C & $\begin{array}{l}\text { See comment at 0111-2.1, "General." conceming } \\
\text { Army Corps of Engineers review. }\end{array}$ & $\begin{array}{l}\text { Ref. } 21 \\
\text { Ref. } 22\end{array}$ \\
\hline
\end{tabular}


EU-S Tank, DOE 6430.1A Design Compliance Review Page 14 of 52

\begin{tabular}{|c|c|c|c|c|}
\hline $\begin{array}{l}\text { DOE } 6430.1 \mathrm{~A} \\
\text { Section }\end{array}$ & DOE 6430.1A Design Criterion & STATUS & Comment & Reference \\
\hline 7III-99.0.2 & 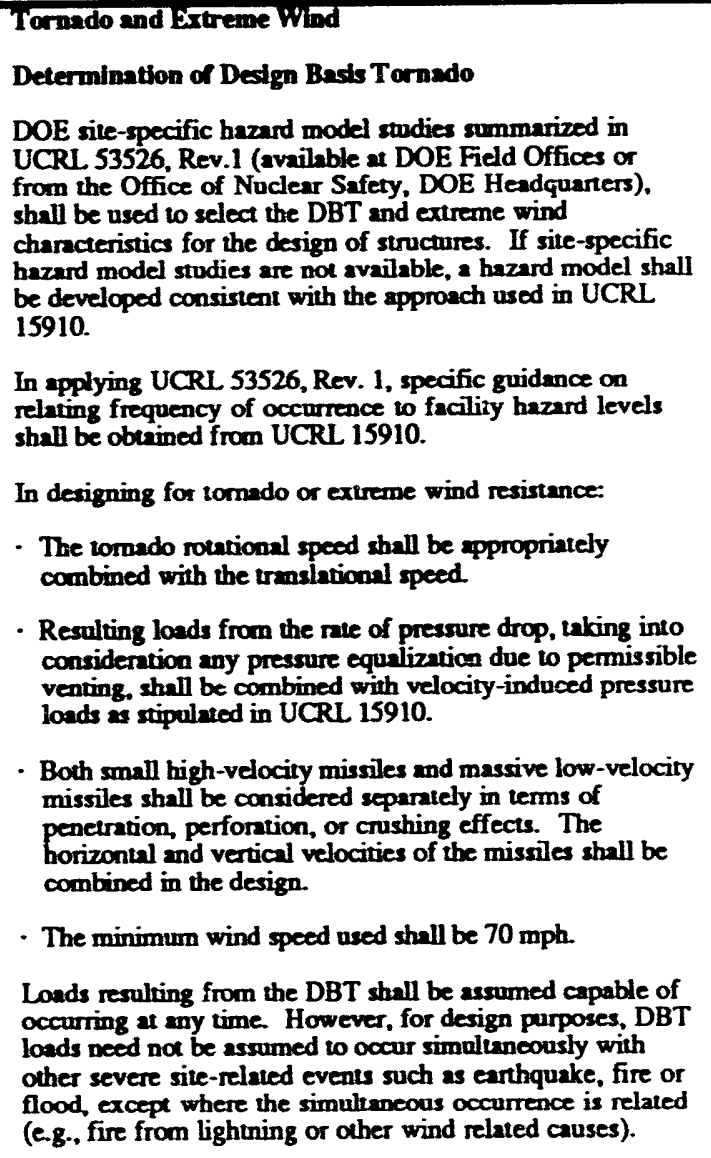 & c & $\begin{array}{l}\text { See conment at 0111-2.1, "General," conceming } \\
\text { Army Corps of Engineers review. }\end{array}$ & $\begin{array}{l}\text { Ref. } 21 \\
\text { Ref. } 22\end{array}$ \\
\hline
\end{tabular}


EU-S Tank, DOE 6430.1A Design Compliance Review Page 15 of 52

\begin{tabular}{|c|c|c|c|c|}
\hline $\begin{array}{c}\text { DOE } 6430.1 \mathrm{~A} \\
\text { Section }\end{array}$ & DOE 6430.1A Design Criterion & STATUS & Comment & Reference \\
\hline \multirow[t]{3}{*}{ OIII-99.0.4 } & 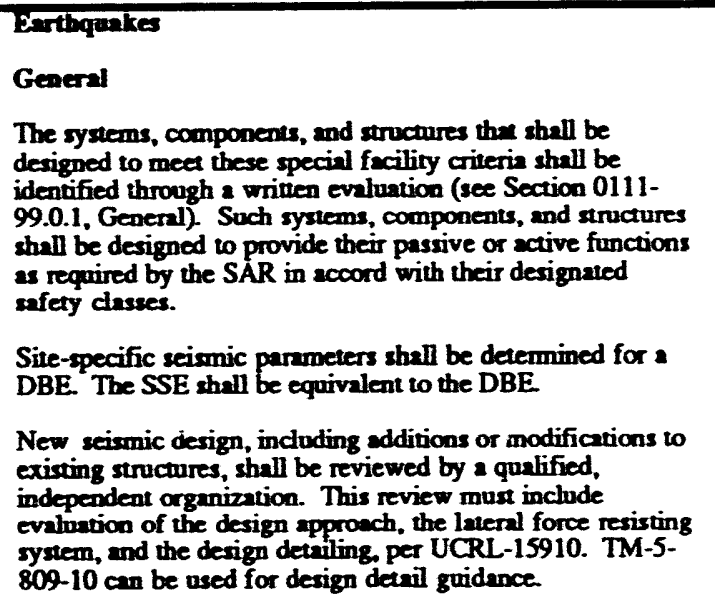 & C & $\begin{array}{l}\text { See comment at 0111-21, "General," concerning } \\
\text { Army Corps of Engineers review. }\end{array}$ & $\begin{array}{l}\text { Ref. } 21 \\
\text { Ref. } 22\end{array}$ \\
\hline & 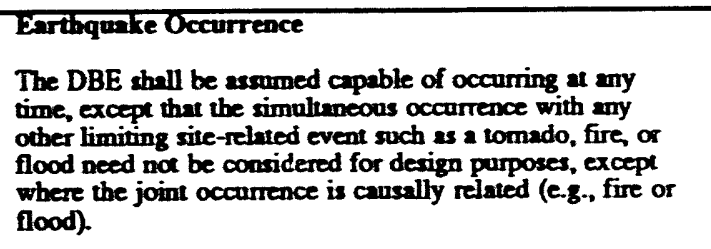 & C & $\begin{array}{l}\text { See comment at 0111-2.1. "General," conceming } \\
\text { Army Corps of Engineers review. }\end{array}$ & $\begin{array}{l}\text { Ref. } 21 \\
\text { Ref. } 22\end{array}$ \\
\hline & 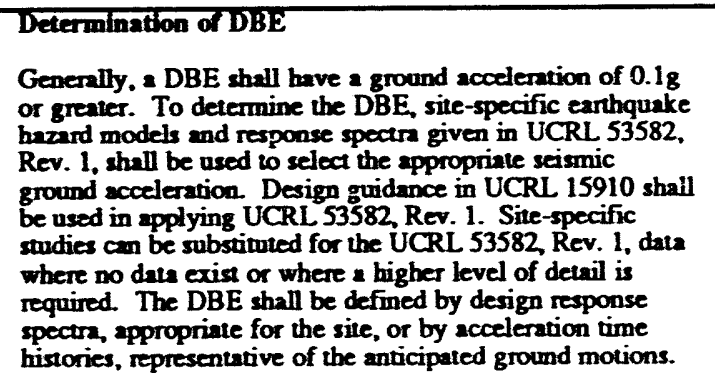 & C & $\begin{array}{l}\text { See comment at } 0111-21, \text { "General," concerning } \\
\text { Army Corps of Engineers review. }\end{array}$ & $\begin{array}{l}\text { Ref. } 21 \\
\text { Ref. } 22\end{array}$ \\
\hline
\end{tabular}




\begin{tabular}{|c|c|c|c|c|}
\hline $\begin{array}{c}\text { DOE } 6430.1 \mathrm{~A} \\
\text { Section }\end{array}$ & DOE 6430.1A Design Criterion & STATUS & Comment & Reference \\
\hline $\begin{array}{l}\text { Oifi-99.0.4 } \\
\text { (conthued) }\end{array}$ & 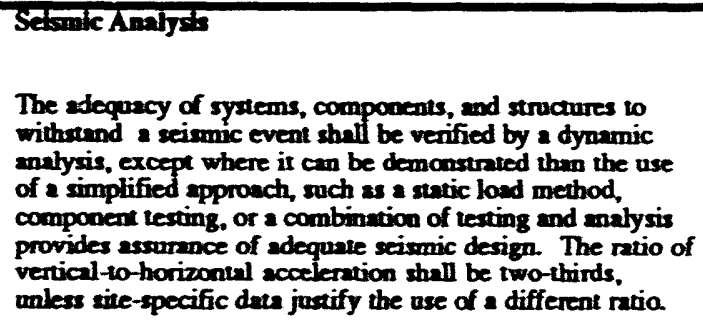 & C & $\begin{array}{l}\text { See comment at 0111-2.1. "General." concerming } \\
\text { Army Corps of Engineers review. }\end{array}$ & $\begin{array}{l}\text { Ref. } 21 \\
\text { Ref. } 22\end{array}$ \\
\hline ग110 & 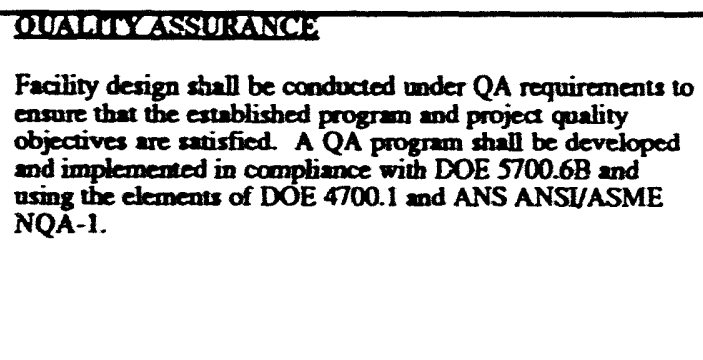 & C & 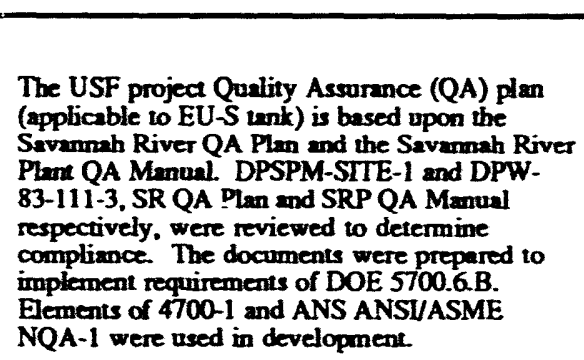 & Ref. 23 \\
\hline & 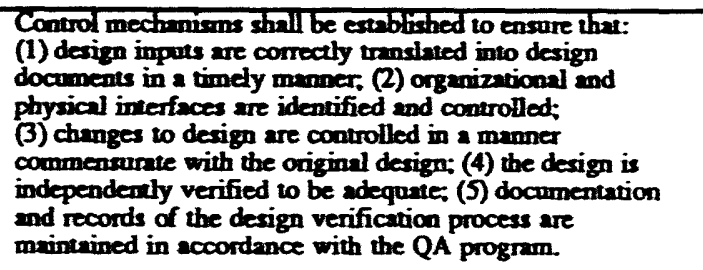 & $c$ & $\begin{array}{l}\text { The USF Project QA Plan complies with these } \\
\text { items. }\end{array}$ & Ref. 24 \\
\hline & 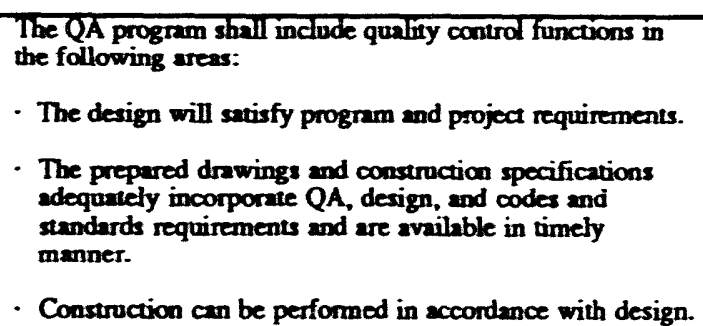 & C & $\begin{array}{l}\text { The USF Project QA Plan complies with these } \\
\text { items. }\end{array}$ & Ref. 24 \\
\hline
\end{tabular}




\begin{tabular}{|c|c|c|c|c|}
\hline $\begin{array}{l}\text { DOE } 6430.1 \mathrm{~A} \\
\text { Section }\end{array}$ & DOE 6430.1A Design Criterion & STATUS & Comment & Reference \\
\hline (conthued) & 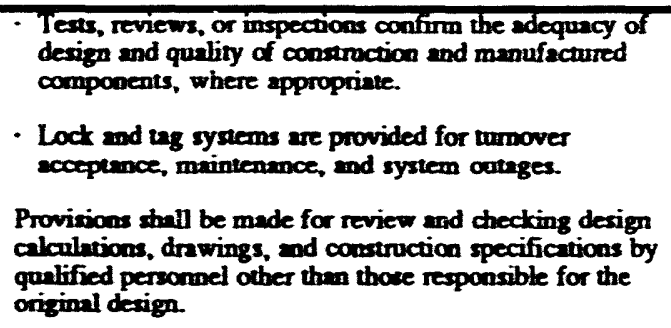 & & & \\
\hline $\begin{array}{l}0200 \\
0200-2\end{array}$ & 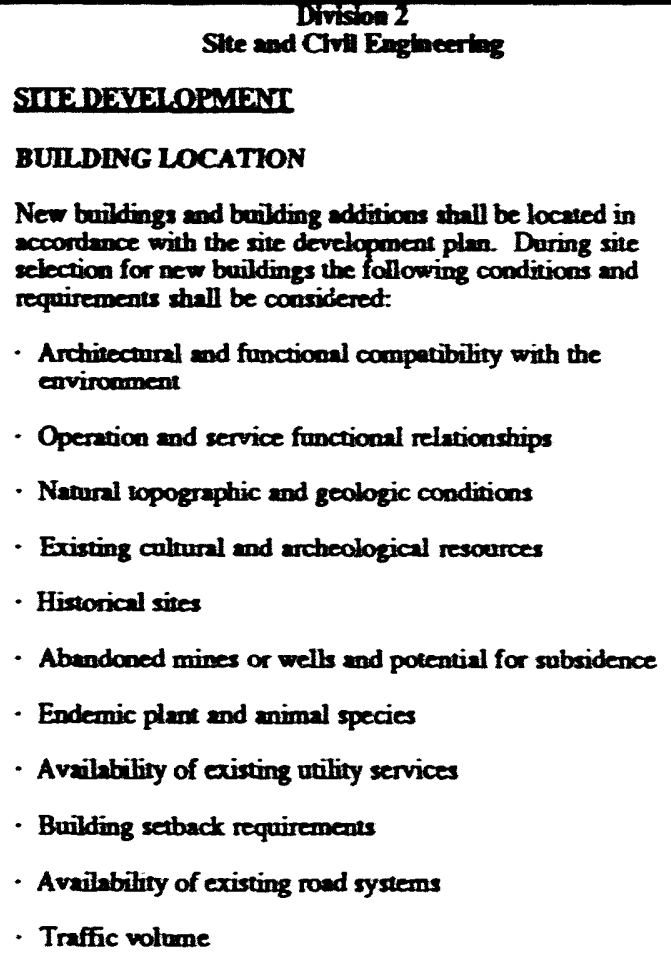 & c & $\begin{array}{l}\text { Applicable siting criteriz are addressed in the } \\
\text { Basic Data Report and Safety Analysis Repor. }\end{array}$ & $\begin{array}{l}\text { Ref. } 1 \\
\text { Ref. } 10\end{array}$ \\
\hline
\end{tabular}




\begin{tabular}{|c|c|c|c|c|}
\hline $\begin{array}{l}\text { DOE } 6430.1 \mathrm{~A} \\
\text { Section }\end{array}$ & DOE 6430.1A Design Criterion & STATUS & Comment & Reference \\
\hline (cometioned) & 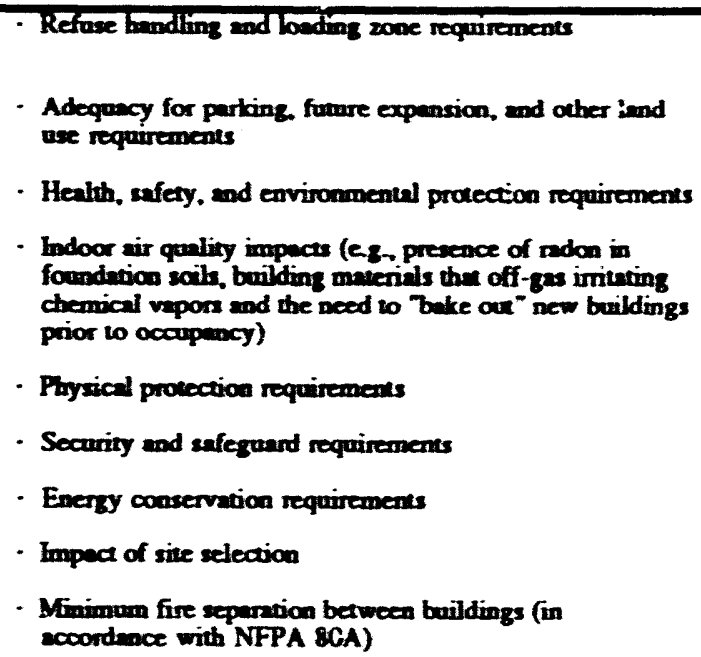 & & & \\
\hline $\begin{array}{l}0200999 \\
0200-99.0 \\
0200-99.0 .1\end{array}$ & 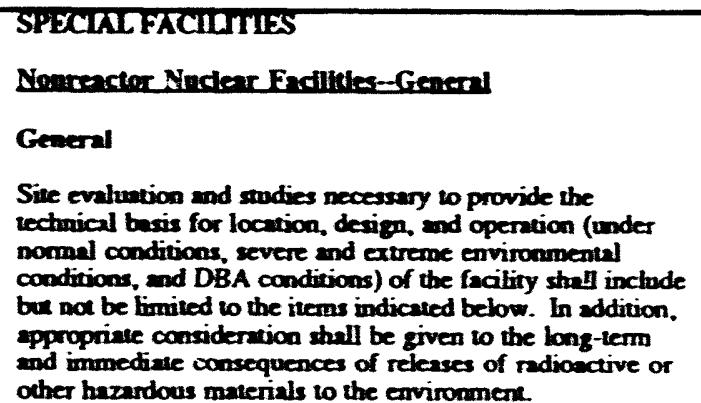 & C & 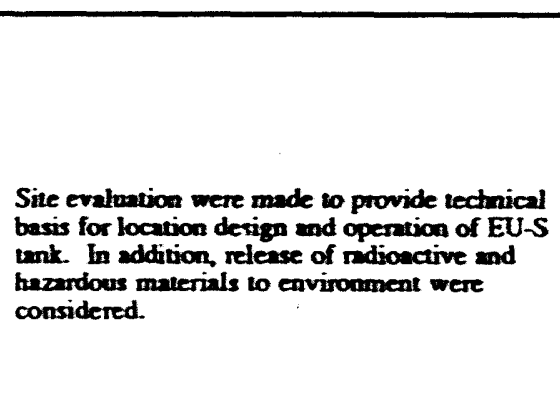 & $\begin{array}{l}\text { Ref. } 1 \\
\text { Ref. IO }\end{array}$ \\
\hline
\end{tabular}




\begin{tabular}{|c|c|c|c|c|}
\hline $\begin{array}{l}\text { DOE 6430.1A } \\
\text { Sectlon }\end{array}$ & DOE 6430.1A Design Criterion & STATUS & Comment & Reference \\
\hline 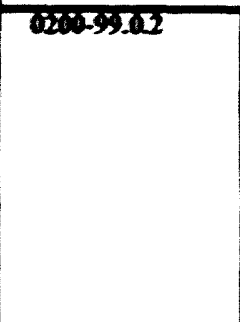 & 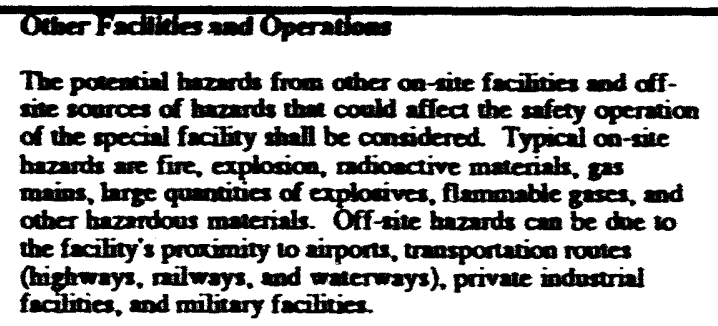 & c & On and off-sive hazards were considered. & $\begin{array}{l}\text { Ref. } 1 \\
\text { Ref. } 10\end{array}$ \\
\hline 020029.03 & 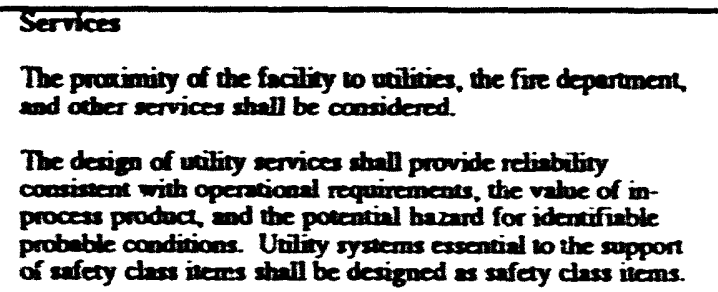 & c & $\begin{array}{l}\text { Location and design of ervices was considered } \\
\text { in desiga and location of EU-S mank }\end{array}$ & $\begin{array}{l}\text { Ref. } 1 \\
\text { Ref. } 10\end{array}$ \\
\hline 02009.44 & 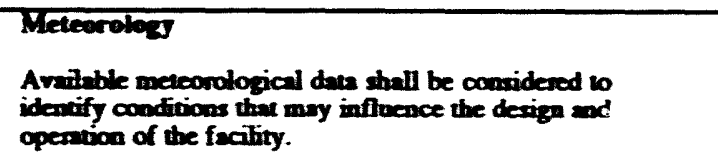 & c & $\begin{array}{l}\text { Meteorologic date were considered in the safery } \\
\text { malysis of EU-S unk and } 211-\mathrm{H}\end{array}$ & Ref. 1 \\
\hline $7200-9905$ & 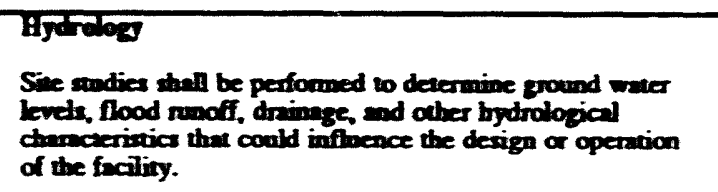 & c & 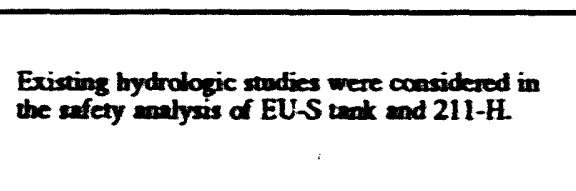 & Ref. 1 \\
\hline 0200.996 & 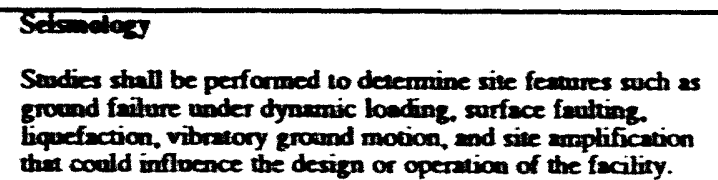 & c & $\begin{array}{l}\text { Existing seismologic stadies were considered in } \\
\text { the safery analysis of EUS Lank and } 211-\mathrm{H} \text {. }\end{array}$ & Ref. 1 \\
\hline
\end{tabular}




\begin{tabular}{|c|c|c|c|c|}
\hline $\begin{array}{c}\text { DOE 6430.1A } \\
\text { Sectlon }\end{array}$ & DOE 6430.1A Design Criterion & status & Comment & Reference \\
\hline \multirow[t]{2}{*}{2011} & 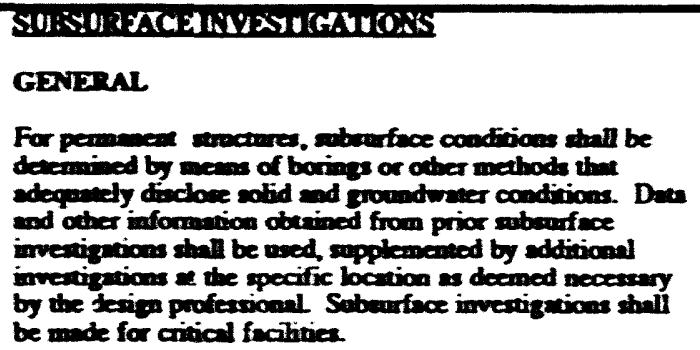 & c & 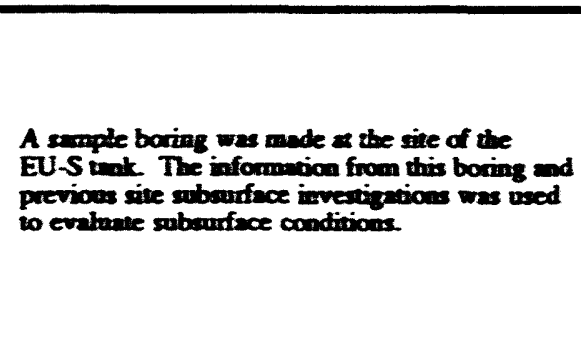 & $\operatorname{Ref} 25$ \\
\hline & 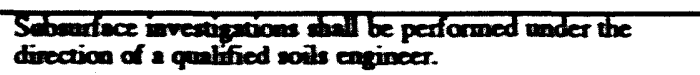 & $c$ & 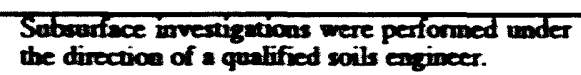 & Ret. 23 \\
\hline Der1-2 & 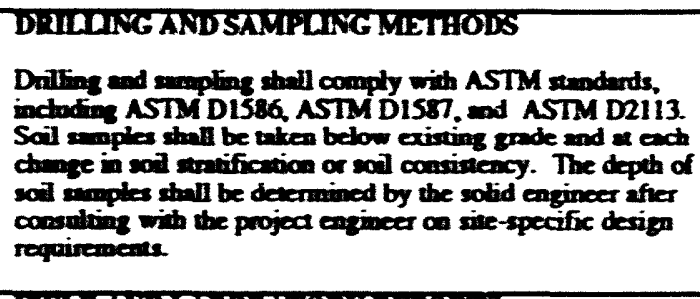 & C & 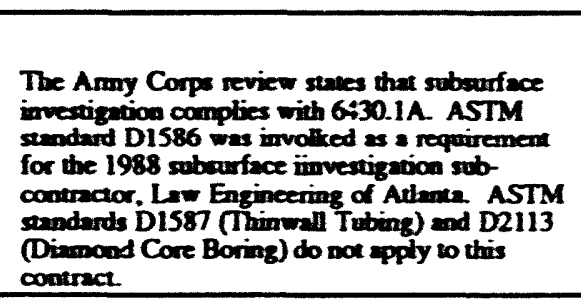 & $\begin{array}{l}\text { Ref. } 22 \\
\text { Ref. } 25\end{array}$ \\
\hline \multirow[t]{4}{*}{$7201-3$} & 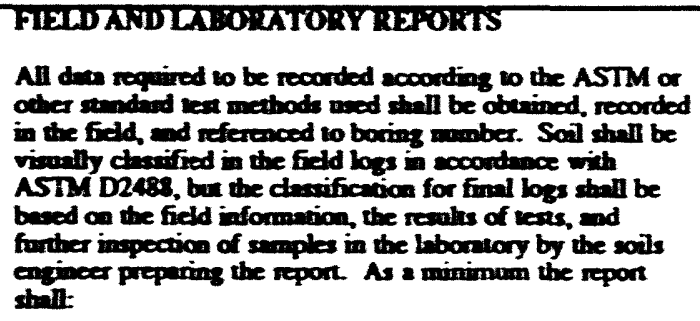 & c & $\begin{array}{l}\text { The documented wed in the reference repont } \\
\text { meet the requirements of ASTM D2488. }\end{array}$ & Ref. 25 \\
\hline & 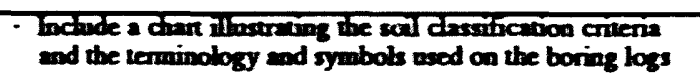 & $c$ & Chart inctoded. & Ret 8 \\
\hline & 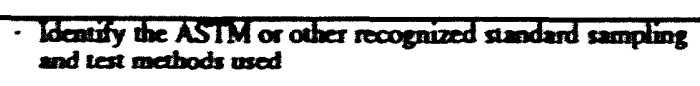 & C & Test methods idenified. & $\begin{array}{l}\text { Ref. } 25 \\
\text { Ref. } 26\end{array}$ \\
\hline & $\begin{array}{l}\text { Provide a plof phen giving dimensionod locations of kest } \\
\text { borings }\end{array}$ & C & Plot plan provided. & Ret. 2 \\
\hline
\end{tabular}




\begin{tabular}{|c|c|c|c|c|}
\hline $\boldsymbol{\Omega} \mathbf{z P y}$ & 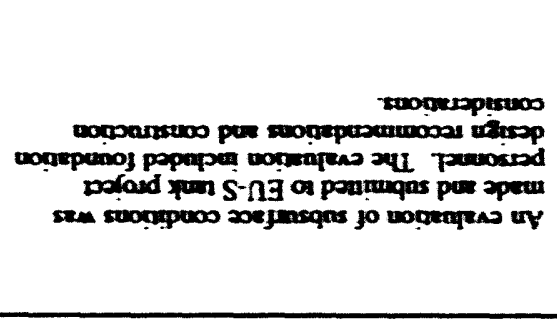 & כ & 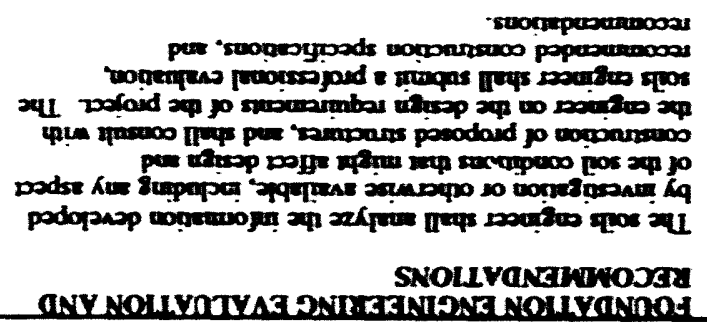 & Elere \\
\hline $\mathscr{C} \boldsymbol{T X}$ & 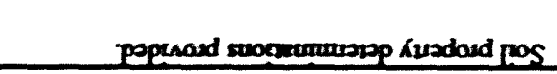 & 2 & 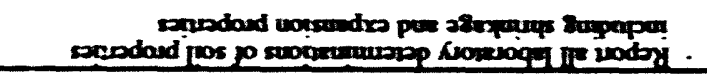 & \\
\hline \&2X & pordpre rove soejunsqus & 2 & 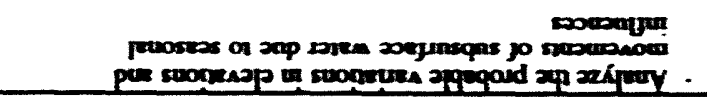 & \\
\hline Gey & popenoud onyord & 2 & 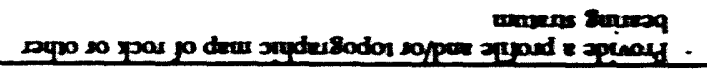 & \\
\hline g. EX & Papnand uopmwory & 2 & 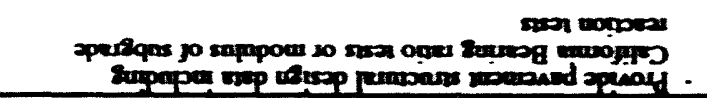 & \\
\hline ㄱex & 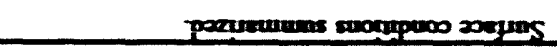 & 2 & 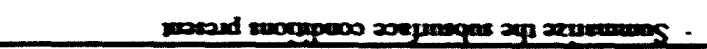 & \\
\hline \& FX & paquosep zuoupuos zongrs & 2 & 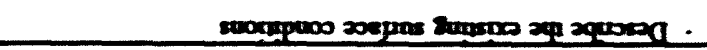 & \\
\hline 工 $12 x$ & 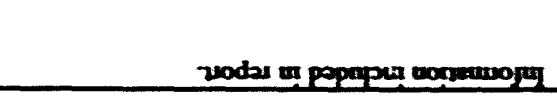 & 2 & 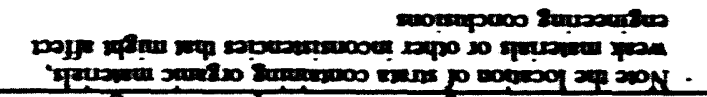 & \\
\hline 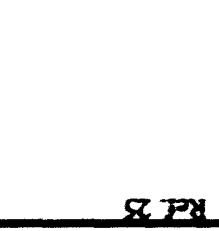 & 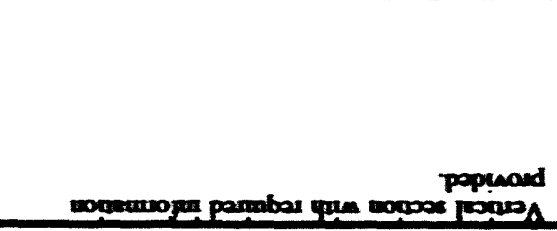 & 2 & 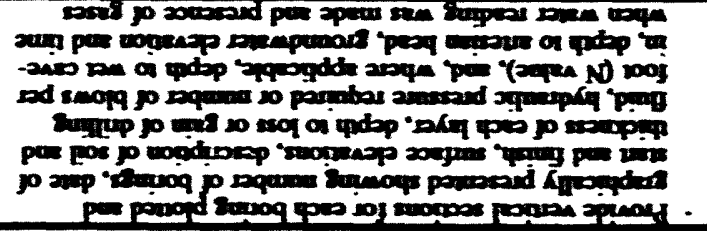 & relexp \\
\hline $00 \cos 20$ & $100=000$ & SnLVIS & 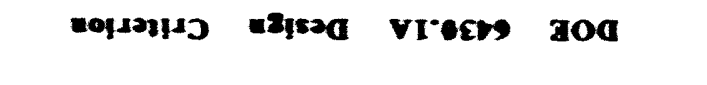 & $\begin{array}{l}=01130 s \\
\text { vioess } 30 a\end{array}$ \\
\hline
\end{tabular}

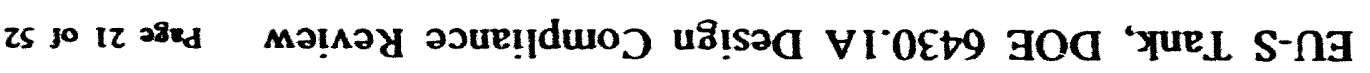


EU-S Tank, DOE 6430.iA Design Compliance Review Page 22 of 52

\begin{tabular}{|c|c|c|c|c|}
\hline $\begin{array}{l}\text { DOE G430.1A } \\
\text { Section }\end{array}$ & DOE 6430.1A Design Criterion & STATUS & Comment & Reference \\
\hline $0235-1$ & 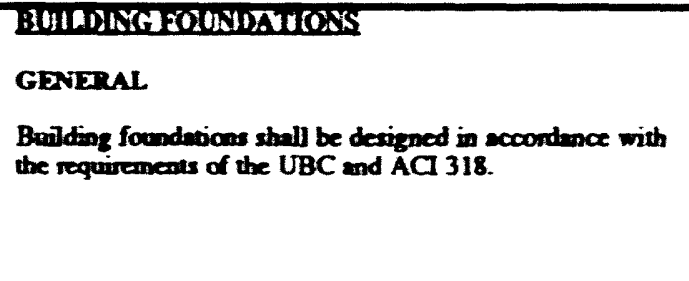 & C & 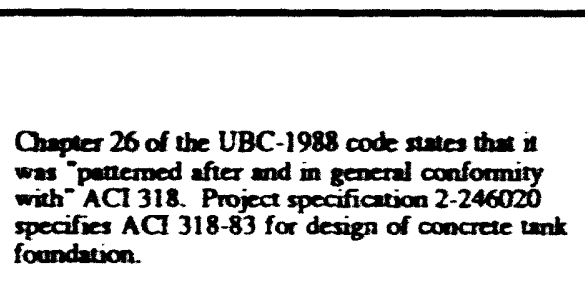 & Ref. 11 \\
\hline $\begin{array}{l}0235-2 \\
0235-22\end{array}$ & 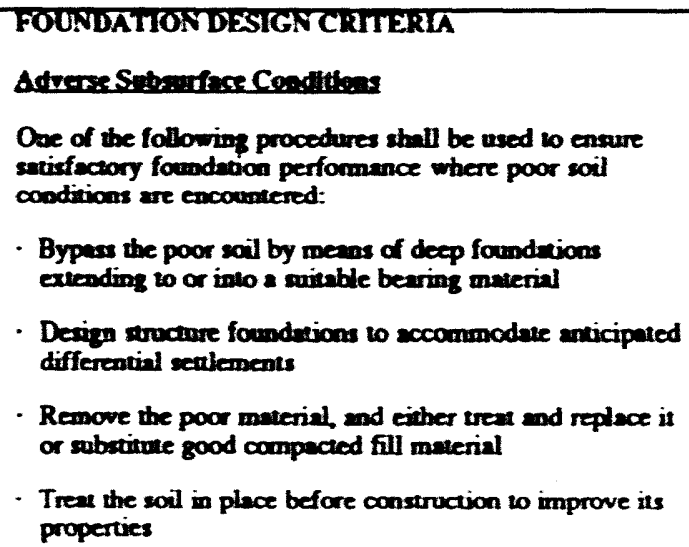 & C & $\begin{array}{l}\text { The old fill wes removed and reused. Fill was } \\
\text { compeceod to minimum } 95 \% \text { of senderd Procior } \\
\text { maximum dy densily. }\end{array}$ & $\begin{array}{l}\text { Ref. } 26 \\
\text { Ref. } 27\end{array}$ \\
\hline $\mathbf{0 2 3 5 - 3}$ & $\begin{array}{l}\text { CONCRETE } \\
\text { Concrele for building founderions shall be designed in } \\
\text { accordence with Section 0330. Cast-In-Place Concrete. }\end{array}$ & & See Section 0330, "Cass-In-Place Concrete." & \\
\hline $\begin{array}{l}0320 \\
0320-1\end{array}$ & $\begin{array}{l}\text { Concrete } \\
\text { CONCRETE REINFORCEMENT } \\
\text { MATERIALS FOR REINFORCEMENT } \\
\text { Reinforcement materials for buildings and other stuctures } \\
\text { shall comply with AC } 318 \text {. }\end{array}$ & C & $\begin{array}{l}\text { Project Specification 2-246020 specifies ACI } \\
318-83 \text { for design of concrete tank foundation. }\end{array}$ & Ref. 11 \\
\hline
\end{tabular}




\begin{tabular}{|c|c|c|c|c|}
\hline $\begin{array}{l}\text { DOE } 6430.1 \mathrm{~A} \\
\text { Section }\end{array}$ & DOE 6430.1A Design Criterion & STATUS & Comment & Reference \\
\hline $\begin{array}{l}0330 \\
0330-2\end{array}$ & 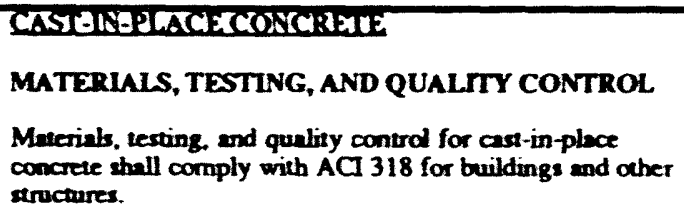 & c & $\begin{array}{l}\text { Projed Specification 2-246020 specifies ACI } \\
318-83 \text { for design of concrete tank foundation. }\end{array}$ & Ref. 11 \\
\hline & $\begin{array}{l}\text { Talernoces for formed concrete shall be as suggested in } \\
\text { ACI } 347 \text {. }\end{array}$ & $C$ & $\begin{array}{l}\text { Concrete was accepted within design tolerances } \\
\text { as set by site specifications. These wolerances } \\
\text { are the sume as ACl } 347 \text {. }\end{array}$ & Ref. II \\
\hline $0330-3$ & 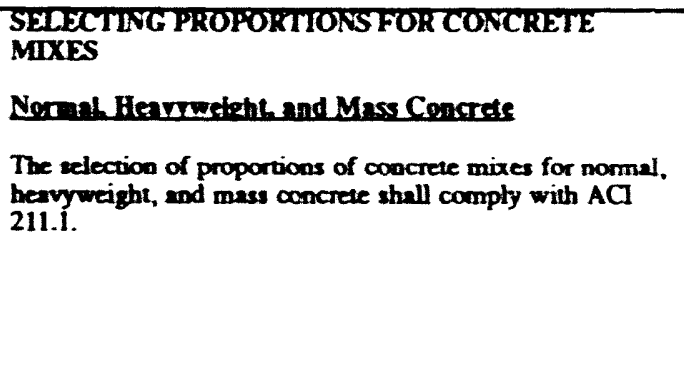 & C & $\begin{array}{l}\text { Project Specification } 2-246020 \text { specifies } \\
\text { ACl-301 for malerials, proportioning and } \\
\text { constructions of structural concrete. ACl } 301 \text { is } \\
\text { a sponsoring document for ACI } 211.1 \text {. } \\
\text { Specification } 2-246020 \text { specifies } 228 \text { day } \\
\text { concrete strength of } 4000 \text { psi which meets ACI } \\
211.1 \text {. }\end{array}$ & Ref. 11 \\
\hline $0330-4$ & $\begin{array}{l}\text { MIXING,TRANSPORTING, AND PLACING } \\
\text { The mixing, transporting, and placing of cast-in-place } \\
\text { concrete stall comply with ACI } 304 \text {. }\end{array}$ & C & $\begin{array}{l}\text { ACl } 318 \text { and } A C I 304 \text { are sponsoring documents } \\
\text { for ACl } 211.1 \text {. Specification } 2-246020 \text { specifies } \\
\text { a } 28 \text { day concrete strength of } 4000 \text { psi which } \\
\text { meetss AC7 } 304 \text {. }\end{array}$ & Ref. 11 \\
\hline $\begin{array}{l}0512 \\
0512-6\end{array}$ & $\begin{array}{l}\text { Division 5 } \\
\text { Metsls }\end{array}$ & C & $\begin{array}{l}\text { Project Specification 2-246020 specifies API } 650 \\
\text { for design of EU-S tank. }\end{array}$ & Ref. 11 \\
\hline
\end{tabular}




\begin{tabular}{|c|c|c|c|c|}
\hline $\begin{array}{c}\text { DOE } 6430.1 \mathrm{~A} \\
\text { Section }\end{array}$ & DOE 6430.1A Design Criterion & STATUS & Comment & Reference \\
\hline $\begin{array}{l}1300 \\
1300-1 \\
1300-1.4 \\
1300-1.42\end{array}$ & $\begin{array}{l}\text { Spectal Fadilities } \\
\text { GENERALREOUIREMENTS } \\
\text { COVERAGE AND OBJECTIVES } \\
\text { Guldance on Limiting Exposure of the Public } \\
\text { Accidental Releases } \\
\text { Releases of hazardous materials postulated to occur as a } \\
\text { result of DBAs shall be limited by designing facilities such } \\
\text { that at least one confinement system remains fully functional } \\
\text { following any credible DBA. }\end{array}$ & c & $\begin{array}{l}\text { The EU-S tank is designed to remain functional } \\
\text { following credible DBAs. }\end{array}$ & $\begin{array}{l}\text { Ref. } 1 \\
\text { Ref. } 10\end{array}$ \\
\hline & 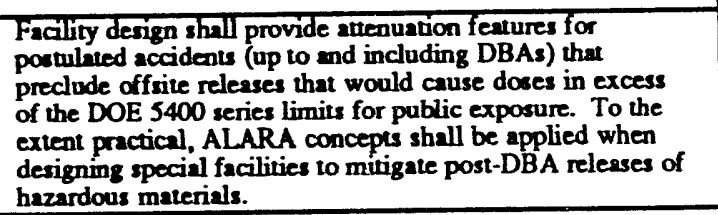 & C & $\begin{array}{l}\text { The EUS tank is designed to limit public } \\
\text { exposure to levels less than DOE } 5400 \text { series } \\
\text { limits for all postulated accidents up to and } \\
\text { including DBA. }\end{array}$ & $\begin{array}{l}\text { Ref. } 1 \\
\text { Ref. } 10 \\
\text { Ref. } 28\end{array}$ \\
\hline $1300-1.43$ & 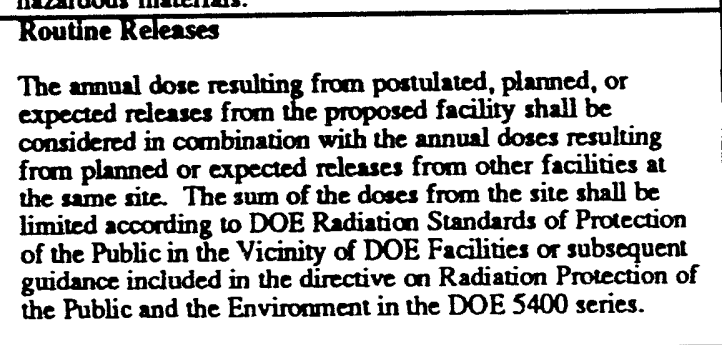 & C & $\begin{array}{l}\text { The annual expected dose from EU-S tank is } \\
\text { considered in combination with remainder of the } \\
\text { site The cumulative dose from the site is limited } \\
\text { in accordance with DOE } 5400 \text { series. }\end{array}$ & Ref. 29 \\
\hline $1300-1.4 .4$ & $\begin{array}{l}\text { Releases shall be monitored in accordance with the } \\
\text { directive on Radiological Effluent Monitoring and } \\
\text { Environmental Surveillance in the DOE } 5400 \text { series. }\end{array}$ & $\mathrm{C}$ & 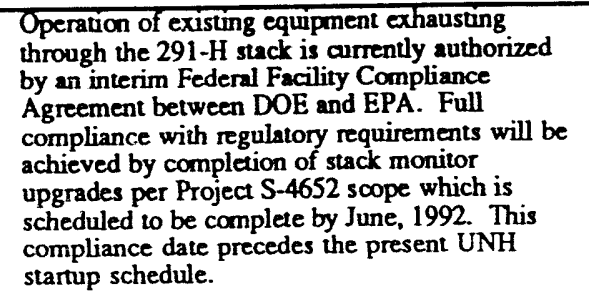 & Ref. 30 \\
\hline
\end{tabular}




\begin{tabular}{|c|c|c|c|c|}
\hline $\begin{array}{l}\text { DOE 6430.1A } \\
\text { Section }\end{array}$ & DOE 6430.1A Design Criterion & STATUS & Comment & Reference \\
\hline $1300-2$ & $\begin{array}{l}\text { SAFETYYANALYYSIS } \\
\text { Safety analysis shall comply with DOE 5481.1B. See also } \\
\text { Section 0110-5.2, Safety Analysis. }\end{array}$ & C & $\begin{array}{l}\text { The SAR, DPSTSA-200-10, SUPP } 11 \text { for EUSS } \\
\text { tank complies with DOE Order 5481.1B. }\end{array}$ & Ref. 1 \\
\hline $\begin{array}{l}1300-3 \\
1300-3.2\end{array}$ & 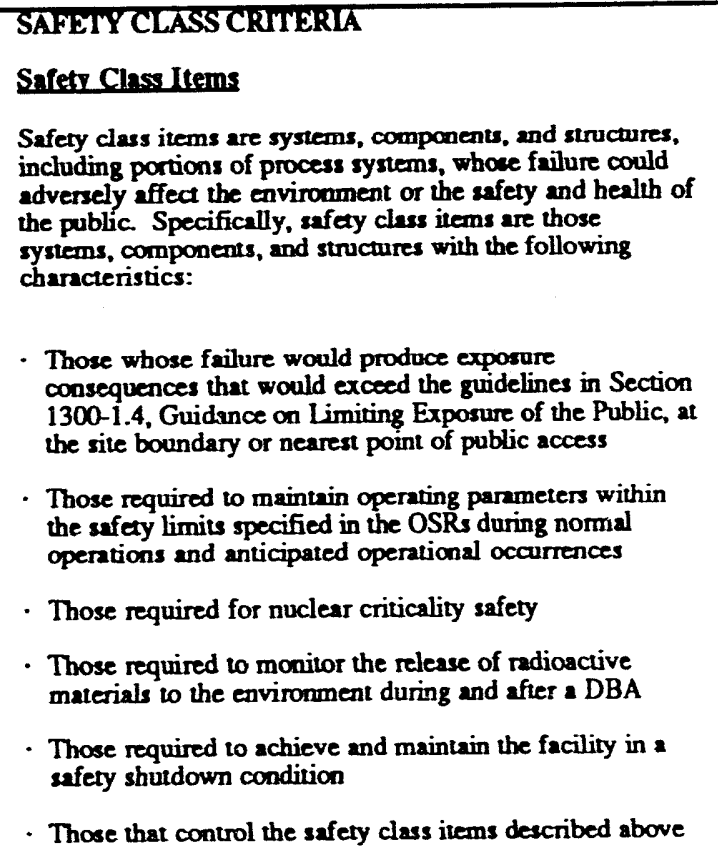 & C & 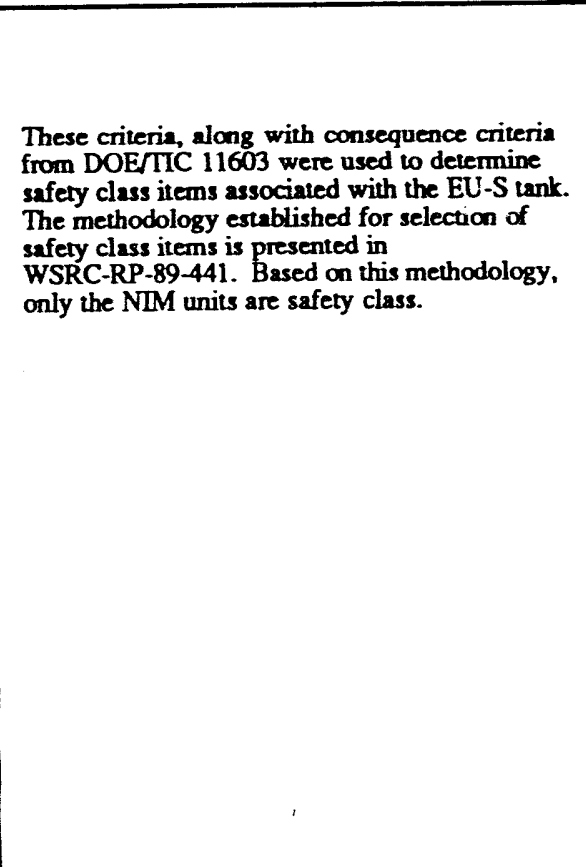 & $\begin{array}{l}\text { Ref. } 31 \\
\text { Ref. } 32\end{array}$ \\
\hline & 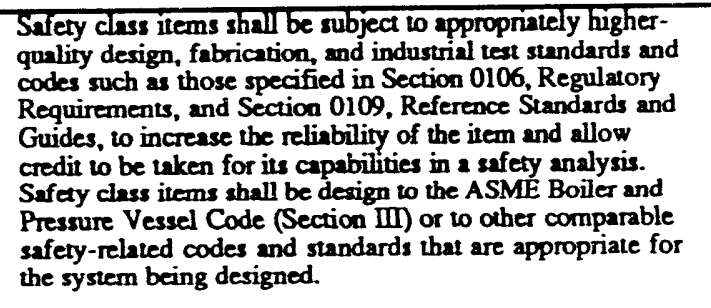 & C & $\begin{array}{l}\text { NIM units are designed, installed and tested in } \\
\text { accordance with approved site specifications. }\end{array}$ & $\begin{array}{l}\text { Ref. } 33 \\
\text { Ref. } 34\end{array}$ \\
\hline
\end{tabular}




\begin{tabular}{|c|c|c|c|c|}
\hline $\begin{array}{l}\text { DOE } 6430.1 A \\
\text { Section }\end{array}$ & DOE 6430.1A Design Criterion & STATUS & Comment & Reference \\
\hline $\begin{array}{l}1300-32 \\
\text { (continued) }\end{array}$ & 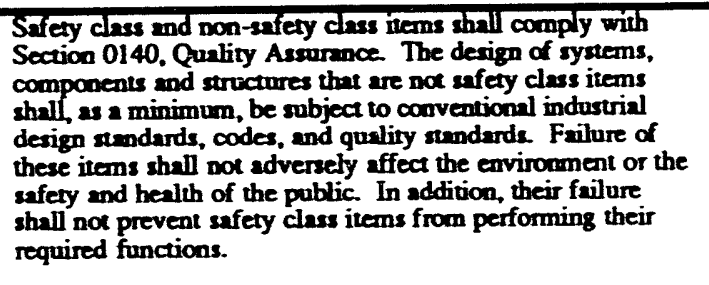 & $c$ & $\begin{array}{l}\text { The project QA plan controls all aspects of } \\
\text { design, procurement, inspection and testing. The } \\
\text { only safety class items are the NIMs. Failure of } \\
\text { non-safey class items will not prevent NIMs } \\
\text { from performing required functions. }\end{array}$ & Rer. 24 \\
\hline $1300-33$ & 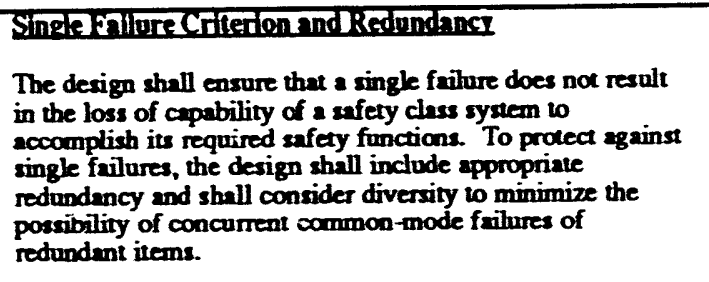 & C & $\begin{array}{l}\text { NIM units are supplied in pairs to ensure that the } \\
\text { failure of ane does not result in loss of monitoring } \\
\text { capability. }\end{array}$ & $\begin{array}{l}\text { Ref. } 1 \\
\text { Ref. } 34\end{array}$ \\
\hline $\begin{array}{l}1300-3.4 \\
1300-3.4 .1\end{array}$ & 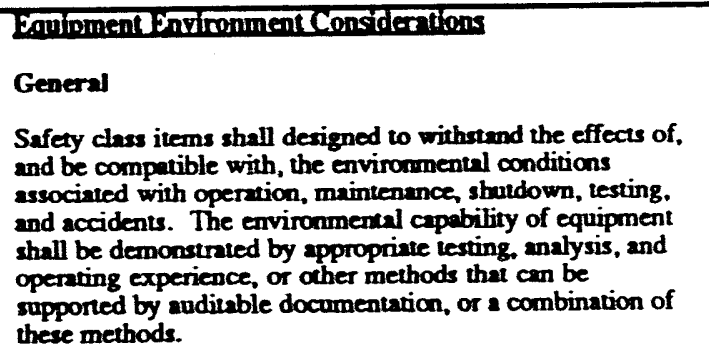 & C & $\begin{array}{l}\text { NIM units are designed and installed to withstand } \\
\text { expected environmental conditions. }\end{array}$ & Ref. 33 \\
\hline $1300-3.42$ & $\begin{array}{l}\text { Envtronmental Qualification of Equipment } \\
\text { Equipment qualification shall provide assurance that safety } \\
\text { class irems will be capable of performing required safery } \\
\text { functions under DBA conditions. The quatification shall } \\
\text { demonstrate that the equipment can at least perform for the } \\
\text { period of time that its safety functions are required. } \\
\text { Subsequent equipment failure, after its safety function is no } \\
\text { longer required, may be allowable. }\end{array}$ & C & $\begin{array}{l}\text { Environmental qualification of NIMs is not } \\
\text { addressed explicity. DPSTM-NIM. Neclear } \\
\text { Instrument Alarm System Technical manual } \\
\text { states that NIM units should be placed so as not to } \\
\text { be affected by steam or radio frequency } \\
\text { interference. The NIMs installed at the EU-S } \\
\text { tank are sheltered from the weather and capable } \\
\text { of performing required safety functions under } \\
\text { DBA conditions. }\end{array}$ & Ref. 34 \\
\hline
\end{tabular}


EU-S Tank, DOE 6430.1A Design Compliance Review Page 27 of 52

\begin{tabular}{|c|c|c|c|c|}
\hline $\begin{array}{c}\text { DOE } 6430.1 \mathrm{~A} \\
\text { Section }\end{array}$ & DOE 6430.1A Design Criterion & STATUS & Comment & Reference \\
\hline $\begin{array}{l}1300-3.42 \\
\text { (continued) }\end{array}$ & 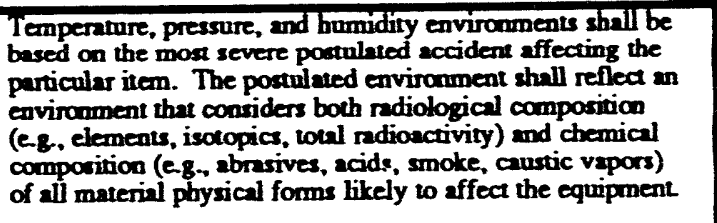 & & & \\
\hline $1300-3.43$ & 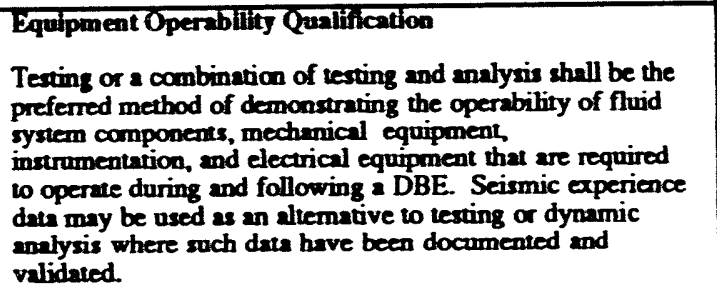 & C & $\begin{array}{l}\text { Site Specification } 9765 \text { requires NIM installation } \\
\text { to remain operational following SRS design besis } \\
\text { carthquake. }\end{array}$ & Ref. 33 \\
\hline $1300-35$ & $\begin{array}{l}\text { Whintenance } \\
\text { Safety class items shall be designed to allow inspection. } \\
\text { maintenance, and testing to ensure their continued } \\
\text { functioning, readiness for operations, and accuracy. }\end{array}$ & c & $\begin{array}{l}\text { NLMs are designed to allow inspection, } \\
\text { maintenance and testing. }\end{array}$ & Ref. 34 \\
\hline & $\begin{array}{l}\text { The design of all process equipment shall include features to } \\
\text { minimize self-contanination of the equipment, piping and } \\
\text { confinement areas. The design of process equipment shall } \\
\text { also include fentures to minimize the spread of } \\
\text { contamination out of local areas. }\end{array}$ & $c$ & $\begin{array}{l}\text { All piping and connecions are wedded to } \\
\text { minimize leakkge. Piping runs are designed to } \\
\text { drain following transfer of UNH. The sample } \\
\text { enclosure drains back to the tank to contain any } \\
\text { spillage. }\end{array}$ & Rer. 10 \\
\hline $1300-3.6$ & 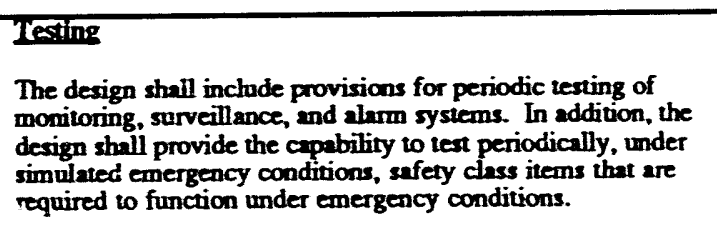 & c & $\begin{array}{l}\text { The design allows for periodic testing of } \\
\text { monitoring, surveillance and alarm systems. }\end{array}$ & Ref. 34 \\
\hline & $\begin{array}{l}\text { The factity design shall allow for rourine in-place lesting of } \\
\text { HEPA filtration systerms es ouclined by ASME NS10. }\end{array}$ & $\mathrm{C}$ & $\begin{array}{l}\text { Design of HEPA filuration systems allows for in } \\
\text { place testing as outlined in ASME N510. }\end{array}$ & Ref. 35 \\
\hline
\end{tabular}




\begin{tabular}{|c|c|c|c|c|}
\hline $\begin{array}{l}\text { DOE } 6430.1 A \\
\text { Section }\end{array}$ & DOE 6430.1A Design Criterion & STATUS & Comment & Reference \\
\hline \multirow[t]{5}{*}{$1300-4$} & $\begin{array}{l}\text { NUCLEAR CRIMICALMY SAFETY } \\
\text { The design of nuclear criticality control provisions, } \\
\text { including equipment mod procodures, shall meet, as a } \\
\text { minimum, the requirements of DOE } 5480.5 \text { and the ANS } 8 \\
\text { series on Nuclear Criticality Sefery. }\end{array}$ & C & $\begin{array}{l}\text { DOE } 5480.5 \text { is referenced in criticality andyris } \\
\text { of the EU-S tonk, while applicable pans of ANS } \\
8 \text { are refesenced in analysis of NIM placement } \\
\text { and Operational Safery Requirements. }\end{array}$ & $\begin{array}{l}\text { Ref. } 13 \\
\text { Ref. } 36\end{array}$ \\
\hline & 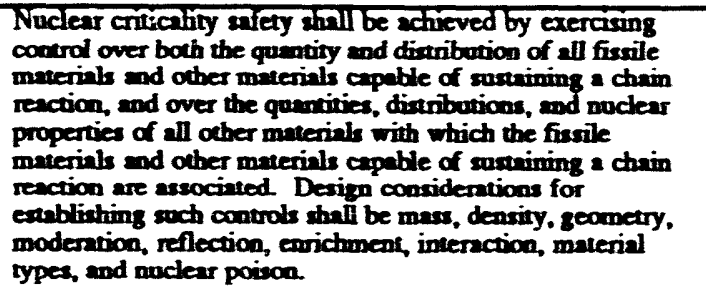 & C & $\begin{array}{l}\text { Noclear criticatity sefey is actreved by } \\
\text { exercising control over U-235 concentuntion in } \\
\text { UNH. }\end{array}$ & Rev. 13 \\
\hline & 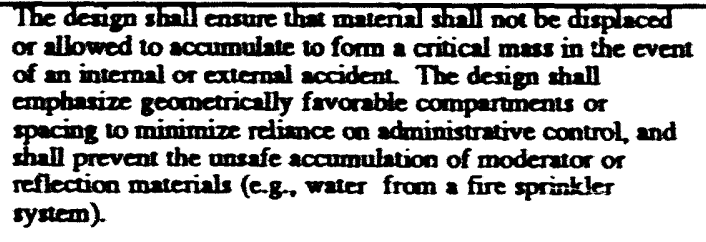 & $\mathrm{C}^{-}$ & 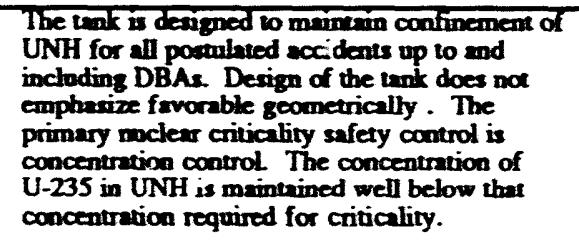 & $\begin{array}{l}\text { Ref. } 1 \\
\text { Ref. } 13\end{array}$ \\
\hline & $\begin{array}{l}\text { Process designs stall incorporate sufficient fuctors of snety } \\
\text { so thet at least two unlikety and independent concurrent } \\
\text { changes must occur in process conditions before a criticality } \\
\text { accident is possible. }\end{array}$ & C & $\begin{array}{l}\text { Double contingency cricality analyses of UNH } \\
\text { tank were performed to detemine sufficient } \\
\text { safety factors in process design. }\end{array}$ & Ref. I \\
\hline & 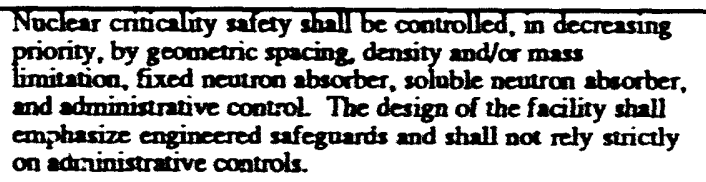 & $\mathrm{C}$ & $\begin{array}{l}\text { The primary nuclear critaclity slety control tor } \\
\text { the UNH tunk is concentration control The } \\
\text { concentration of U-235 in UNH is maintained } \\
\text { well below that concentration required for } \\
\text { criticality. }\end{array}$ & Ref. 13 \\
\hline
\end{tabular}




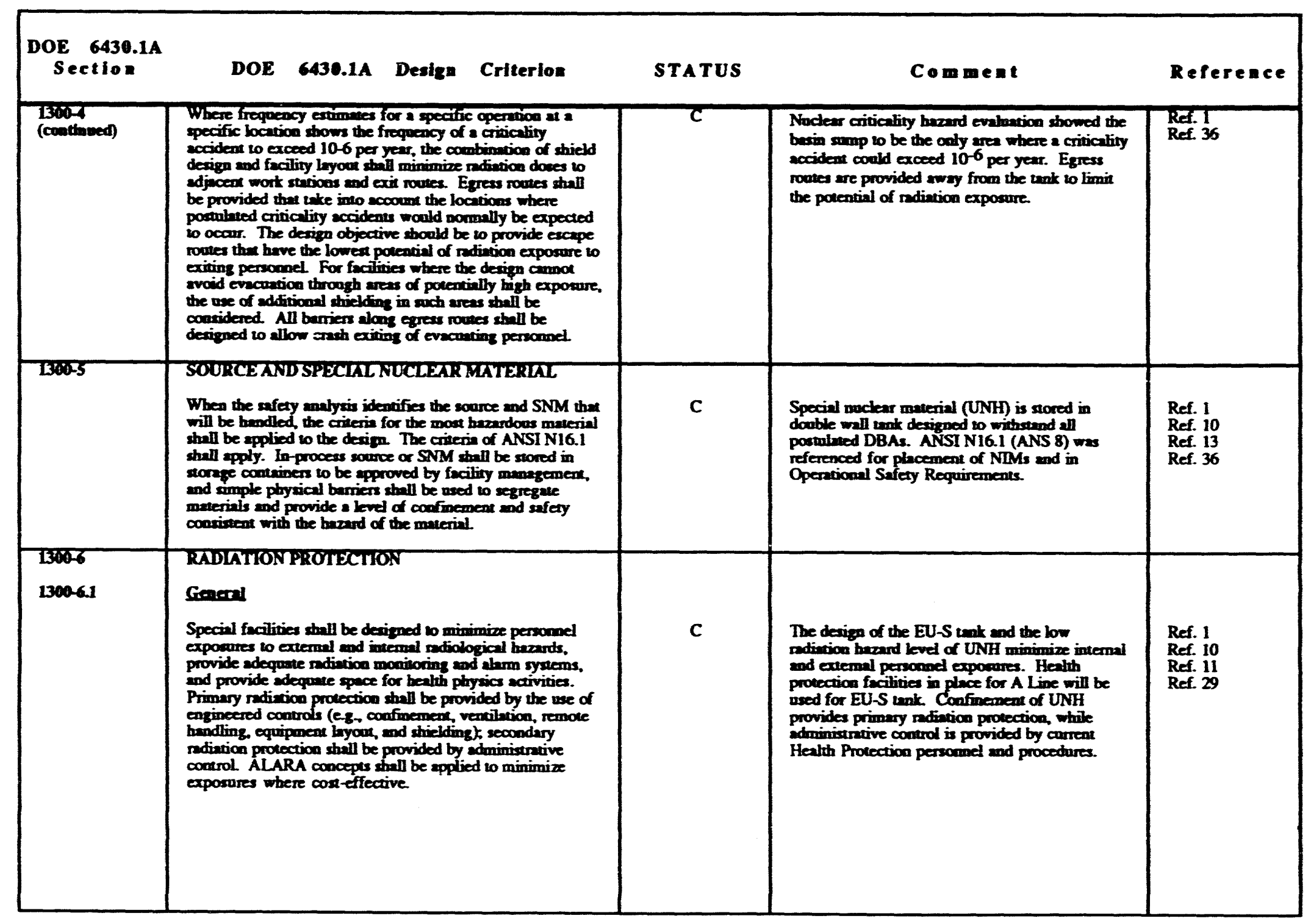


EU-S Tank, DOE 6430.1A Design Compliance Review Page 30 of 52

\begin{tabular}{|c|c|c|c|c|}
\hline $\begin{array}{l}\text { DOE 6430.1A } \\
\text { Section }\end{array}$ & DOE 6430.1A Design Criterion & STATUS & Comment & Reference \\
\hline $\begin{array}{l}1360-65 \\
1300-65.1\end{array}$ & 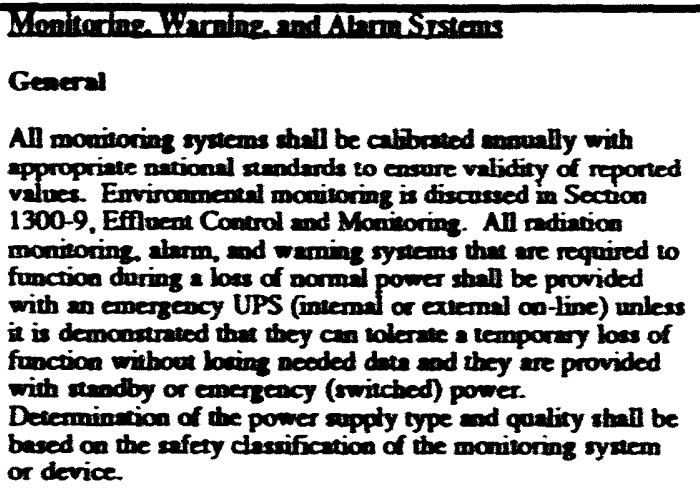 & C & 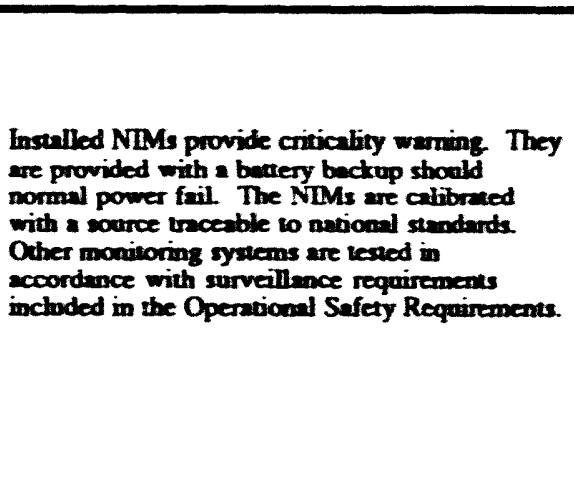 & $\begin{array}{l}\text { Ref. } 13 \\
\text { Ref. } 33 \\
\text { Ref. } 34\end{array}$ \\
\hline EHob-6.5 & 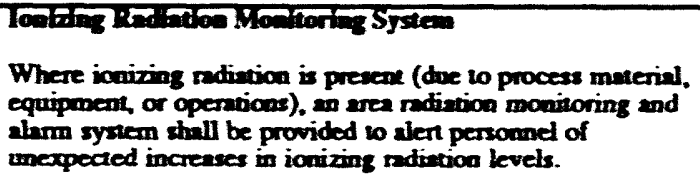 & C & $\begin{array}{l}\text { Noclear incident moniton are provided to warn } \\
\text { personel of inadvenent criticality. }\end{array}$ & Ref. 1 \\
\hline $1300-655$ & 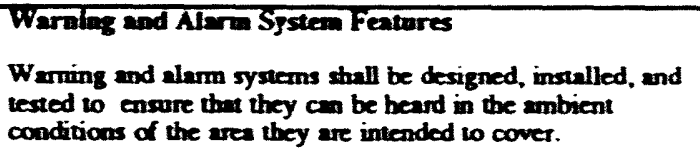 & C & $\begin{array}{l}\text { Site Specification } 9765 \text { requires NIM units to be } \\
\text { installed and lexted to ensure they can be heard } \\
\text { in ambient conditions. }\end{array}$ & Ref. 33 \\
\hline 13306.65 .7 & 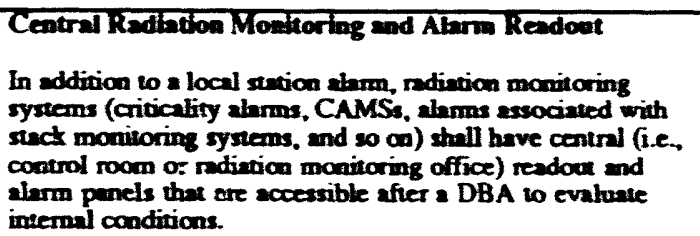 & C & $\begin{array}{l}\text { Indication of garmma levets as EU-S tank are } \\
\text { provided in } 21 \text {-H ocentrol room. This allows } \\
\text { evaluation following NIM alarm. }\end{array}$ & Ref. 37 \\
\hline
\end{tabular}




\begin{tabular}{|c|c|c|c|c|}
\hline $\begin{array}{l}\text { DOE 6430.1A } \\
\text { Section }\end{array}$ & Design Criterion & STATUS & Coment & Reference \\
\hline $\begin{array}{l}\text { Lbiat } \\
1309-72\end{array}$ & 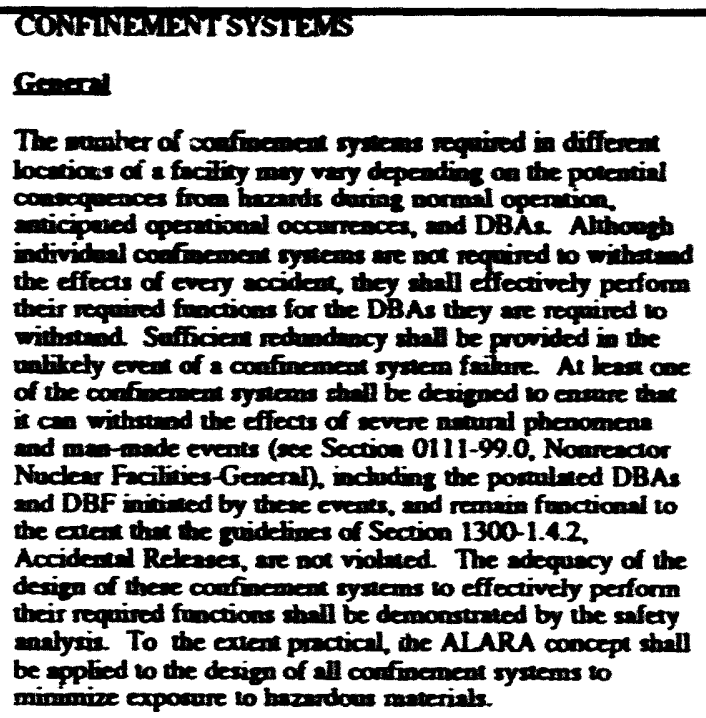 & C & 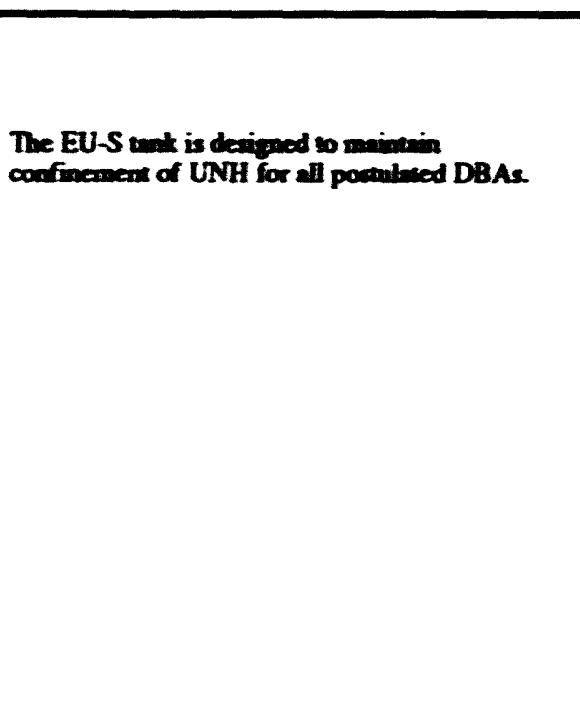 & $\begin{array}{l}\text { Ref. } 1 \\
\text { Red. } 10\end{array}$ \\
\hline $\begin{array}{l}13065 \\
1300-85\end{array}$ & 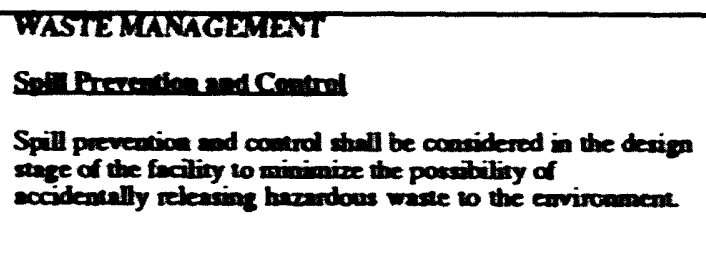 & c & 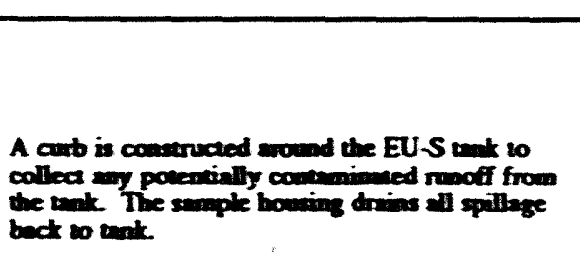 & $\begin{array}{l}\text { Ref. } 10 \\
\text { Ref. } 38\end{array}$ \\
\hline TE0086 & 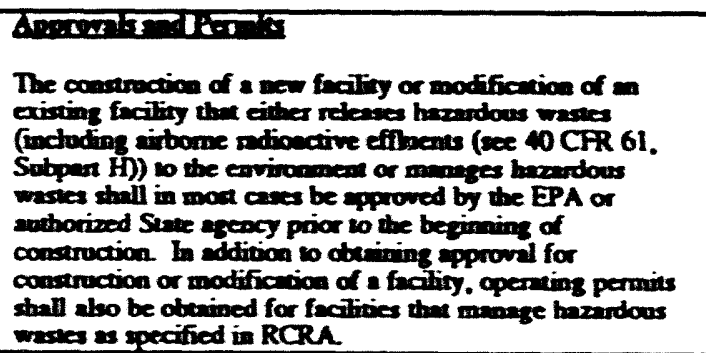 & C & 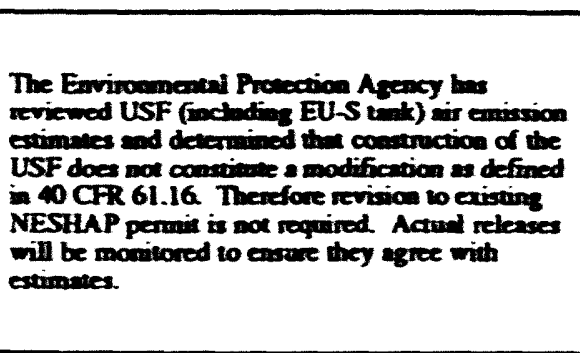 & Ref. 8 \\
\hline
\end{tabular}




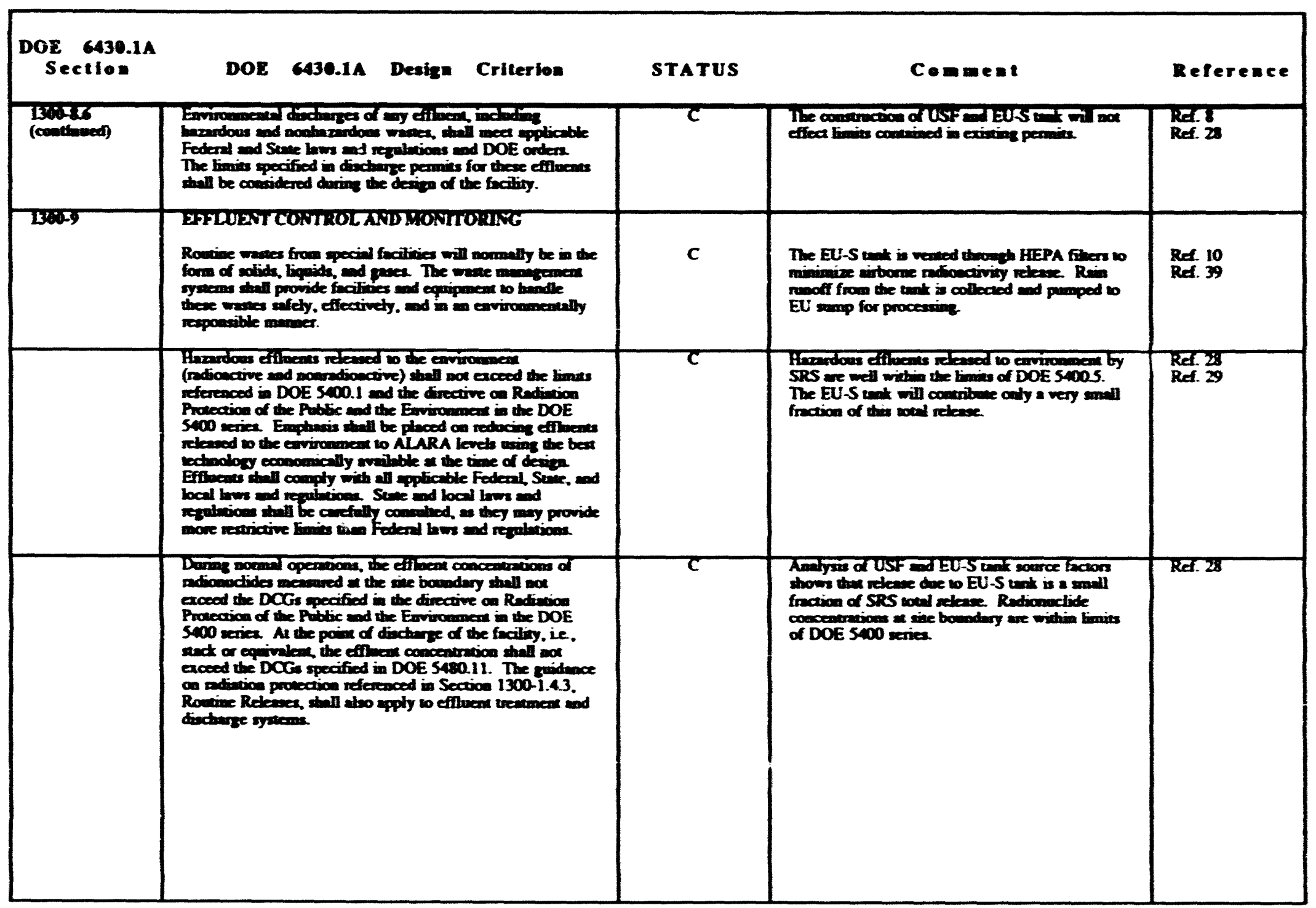




\begin{tabular}{|c|c|c|c|c|}
\hline $\begin{array}{l}\text { DOE 6430.1A } \\
\text { Section }\end{array}$ & DOE G43e.1A Desten Criterios & STATUS & Compent & Reference \\
\hline $\begin{array}{l}\text { 1500-10 } \\
1300-102 \\
1300-10.23\end{array}$ & 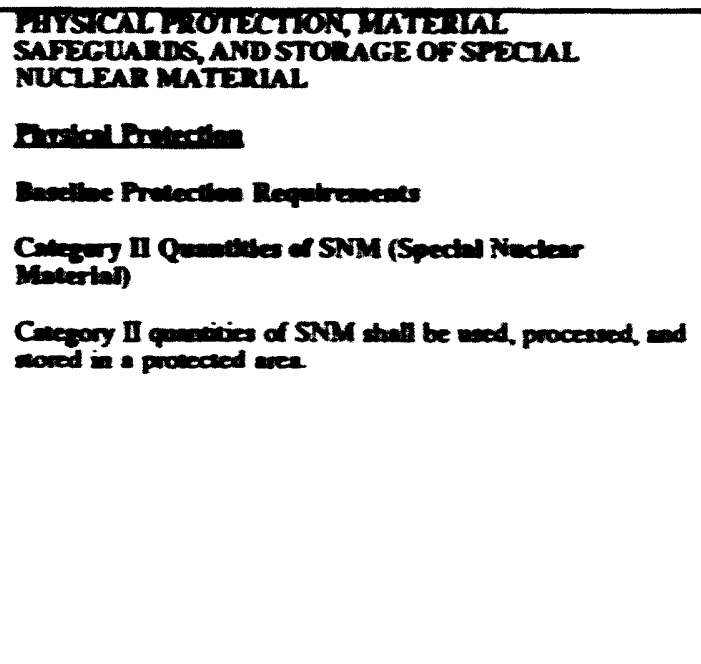 & c & 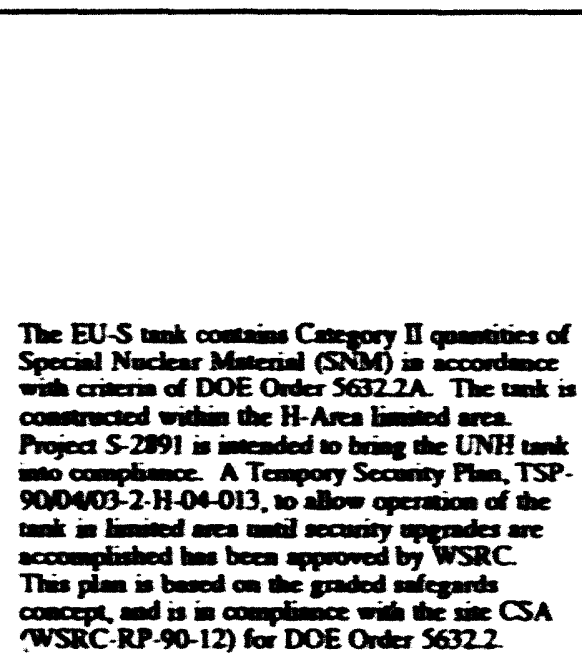 & Ref. 14 \\
\hline & 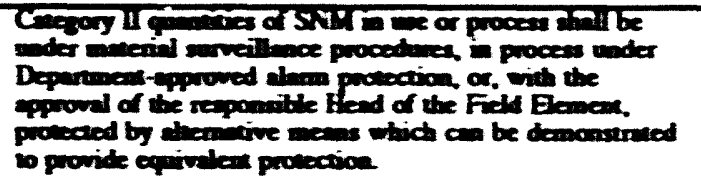 & c & 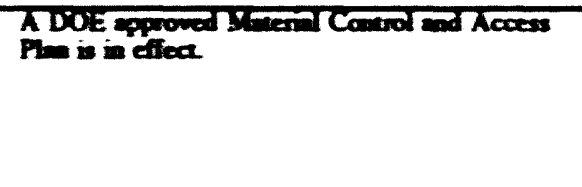 & ReTr \\
\hline $130-1025$ & 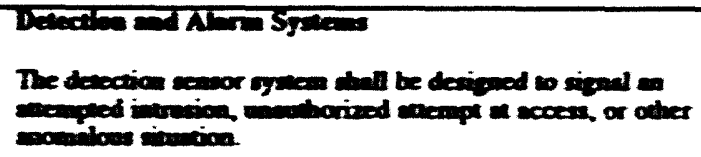 & c & 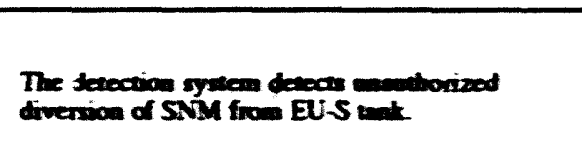 & Ref. 14 \\
\hline & 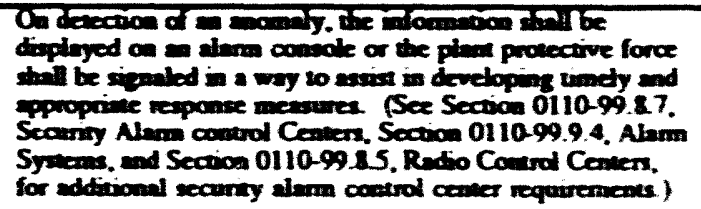 & c & 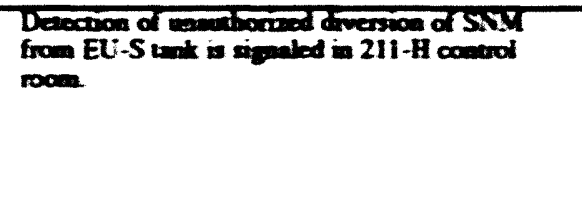 & Re. 14 \\
\hline
\end{tabular}


EU-S Tank, DOE 6430.1A Design Compliance Review

Page 34 of 52

\begin{tabular}{|c|c|c|c|c|}
\hline $\begin{array}{c}\text { DOE GA30.1A } \\
\text { Sectlo: }\end{array}$ & DOE G430.1A Design Criterion & STATUS & Comeent & Deferesce \\
\hline $1360-10.32$ & 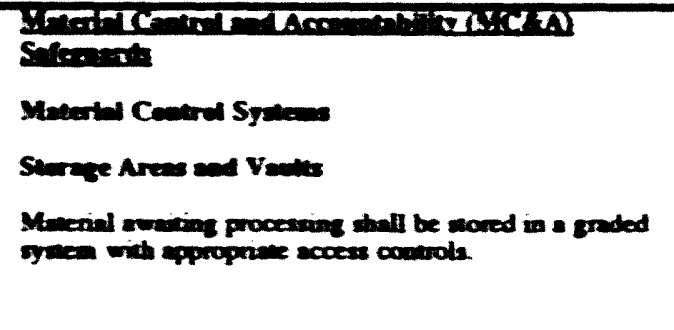 & c & 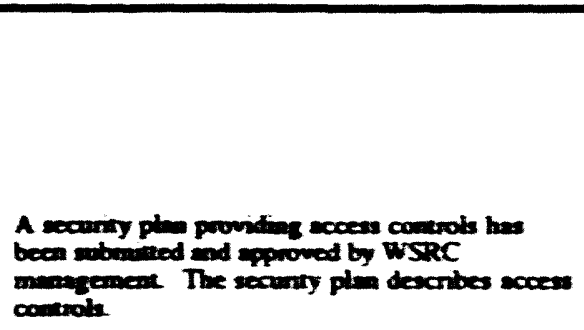 & Ref. 14 \\
\hline TBMTISB & 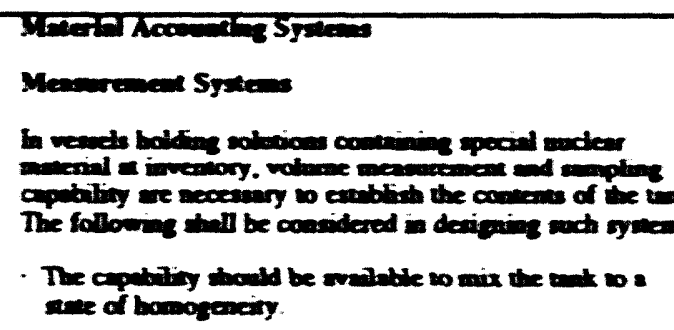 & c & Tuat mixime coptitisy provided. & Ref. 10 \\
\hline & 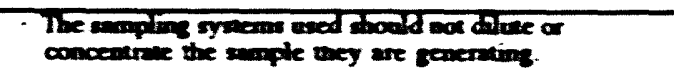 & C & 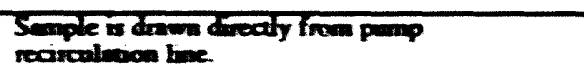 & Re 10 \\
\hline & 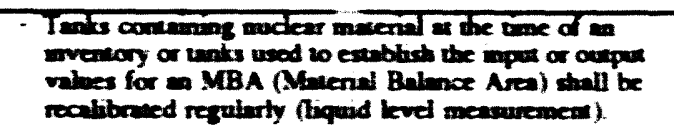 & C & 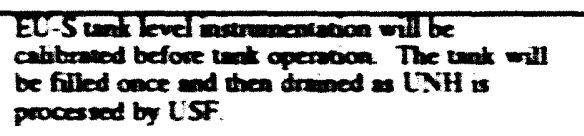 & Ref $\$$ \\
\hline
\end{tabular}


EU-S Tank, DOE 6430.1A Design Compliance Review Page 35 of 52

\begin{tabular}{|c|c|c|c|c|}
\hline $\begin{array}{c}\text { DOE G430.1A } \\
\text { Sectlod }\end{array}$ & DOE Ga30.1A Design Criterion & STATUS & Condent & Reference \\
\hline $\begin{array}{l}\text { burII } \\
\text { 13e-11.1 }\end{array}$ & 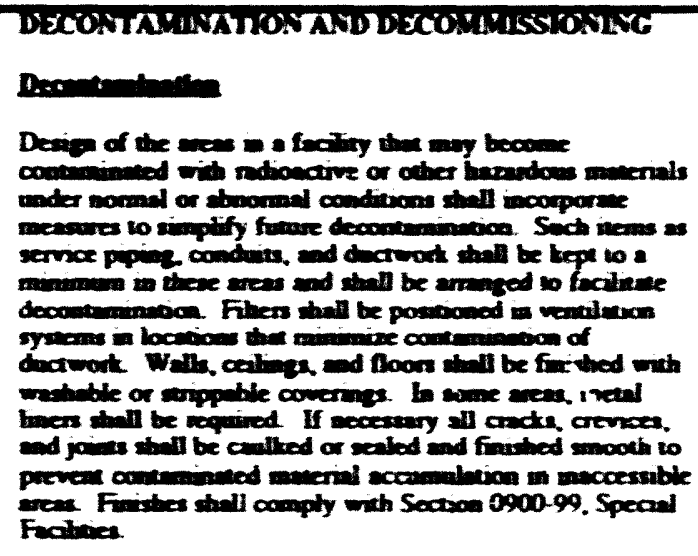 & c & 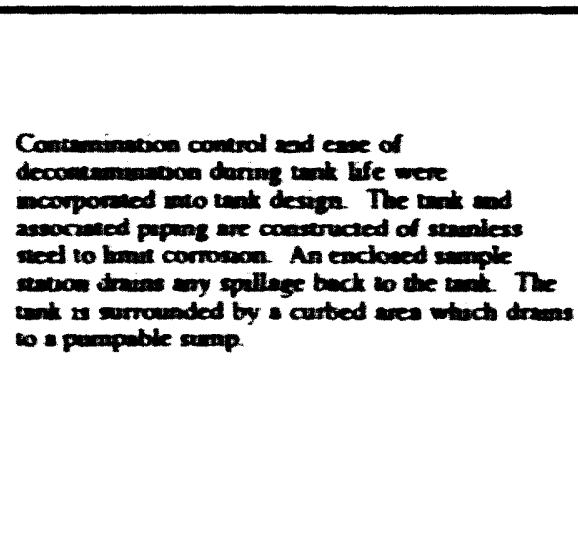 & $\begin{array}{l}\text { Ref. 1 } \\
\text { Ref. io } \\
\text { Ref. it } \\
\text { Ref. } 38 \\
\text { Ret. } 39\end{array}$ \\
\hline TE:TाI? & 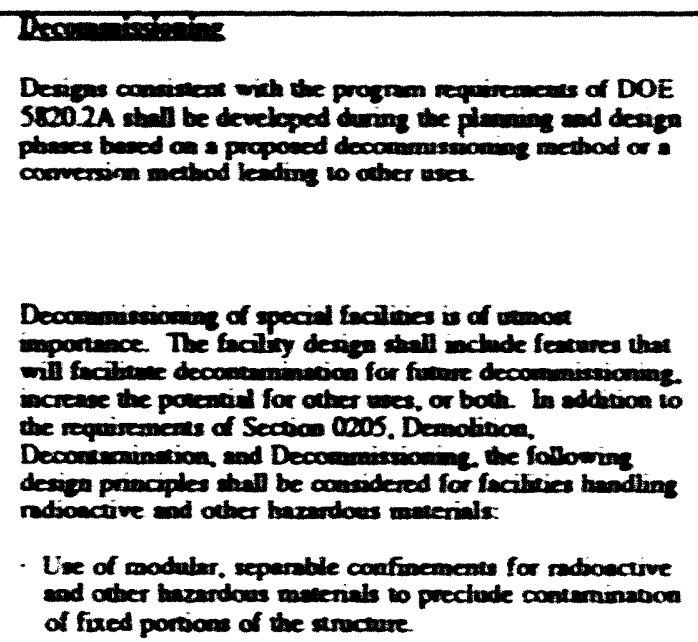 & C & 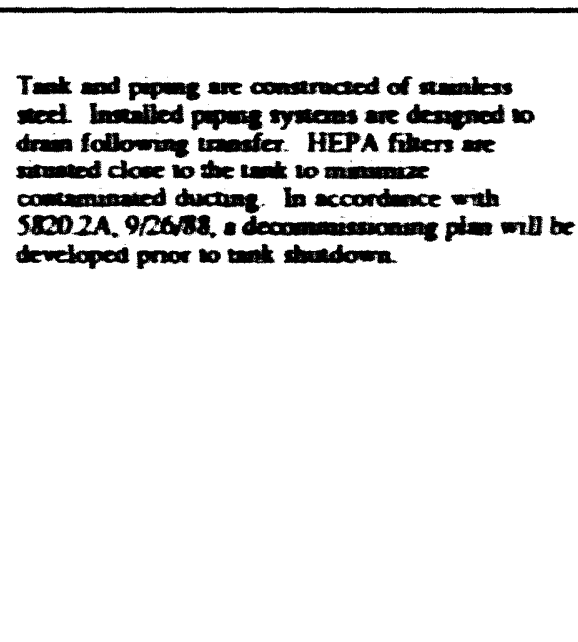 & $\begin{array}{l}\text { Ref. I } \\
\text { Ref. } 10 \\
\text { Ref. } 11 \\
\text { Red } 38 \\
\text { Ref. } 39\end{array}$ \\
\hline
\end{tabular}


EU-S Tank, DOE 6430.1A Design Compliance Review

Page 36 of 52

\begin{tabular}{|c|c|c|c|c|}
\hline $\begin{array}{l}\text { DOE C430.1A } \\
\text { Section }\end{array}$ & DOE GA30.1A Design Criterion & STATUS & Coment & Referesce \\
\hline 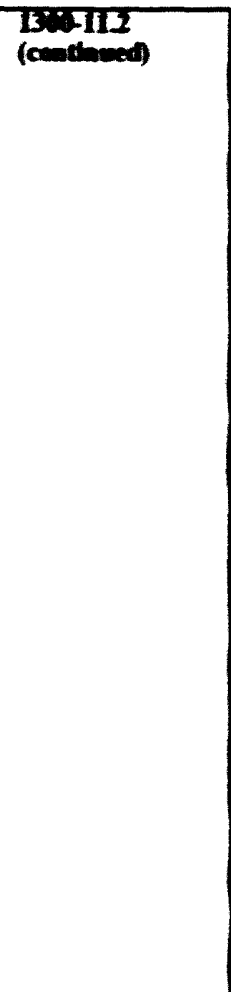 & 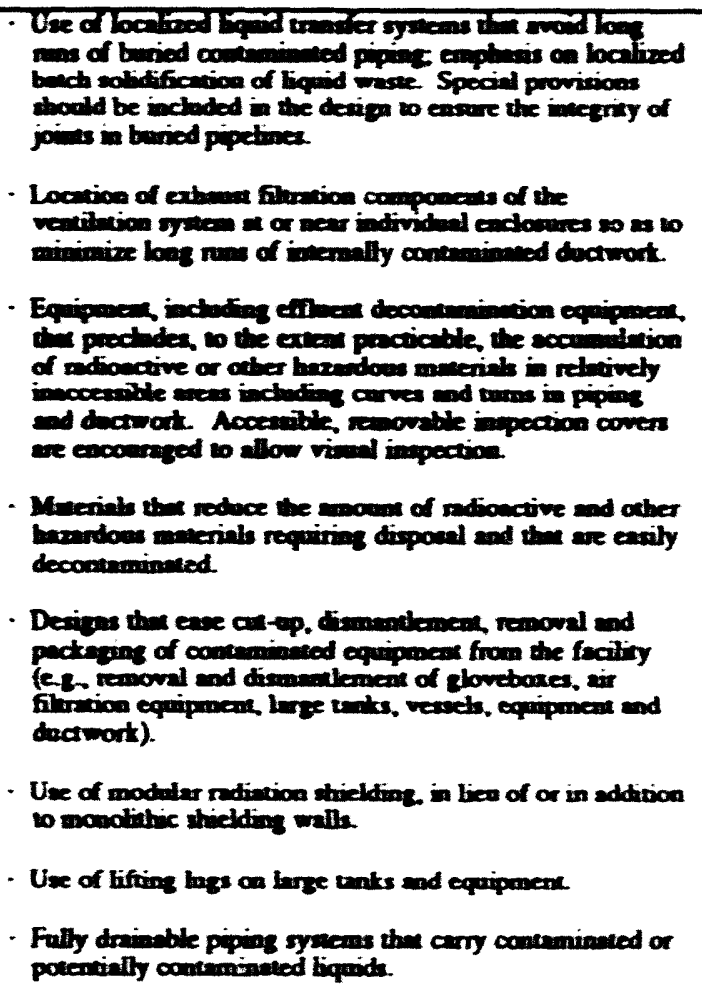 & & & \\
\hline $\begin{array}{l}\text { IBt5 } \\
13064\end{array}$ & 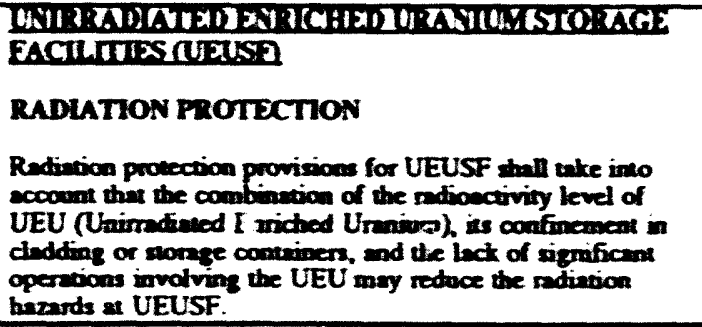 & C & $\begin{array}{l}\text { Redincion protection in adtressed in } \\
\text { DPSTSA-200-10. SUPP } 11 \text {. }\end{array}$ & Ref. 1 \\
\hline
\end{tabular}




\begin{tabular}{|c|c|c|c|c|}
\hline $\begin{array}{c}\text { DOE 6430.1A } \\
\text { Sectlon }\end{array}$ & DOE 6430.1A Design Criterion & STATUS & $C \circ m=e n t$ & Reference \\
\hline \multirow[t]{2}{*}{$7306-5$} & 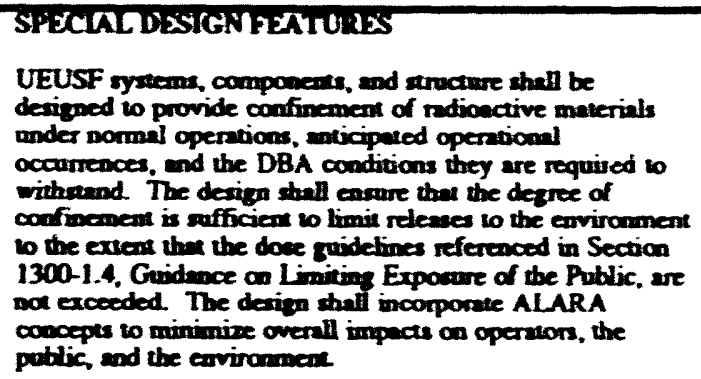 & C & 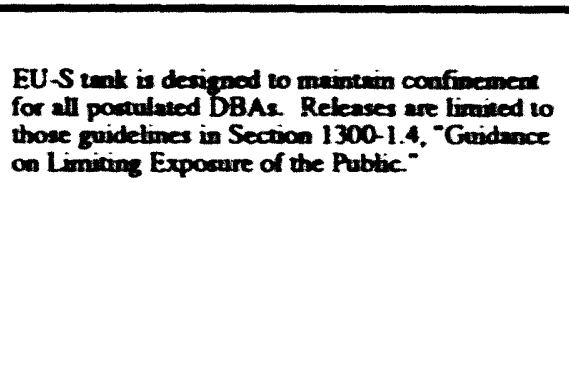 & $\begin{array}{l}\text { Ref. } 1 \\
\text { Ref. } 10\end{array}$ \\
\hline & 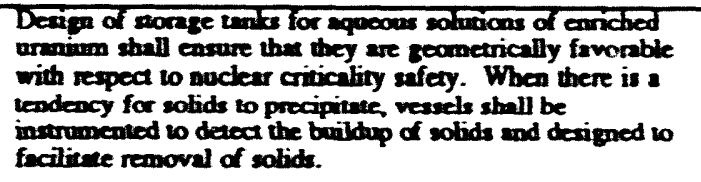 & C & 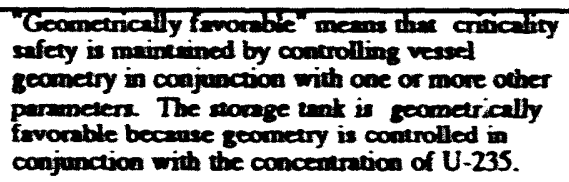 & Ret 13 \\
\hline $\begin{array}{l}1306-6 \\
1306-6.1\end{array}$ & 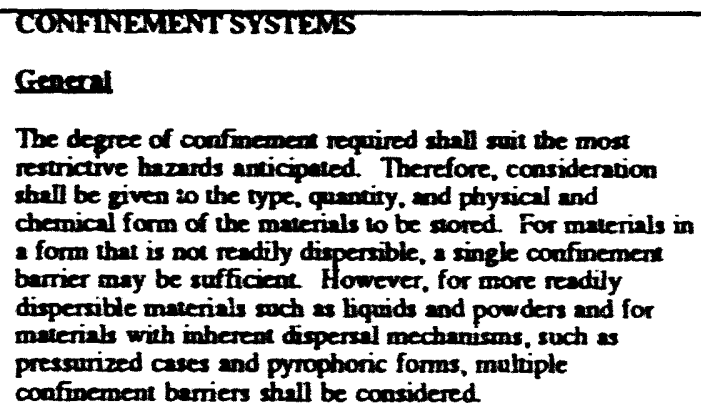 & C & $\begin{array}{l}\text { Primary and seconatary confinement is provided } \\
\text { by EU'S unk }\end{array}$ & $\begin{array}{l}\text { Ref. } 1 \\
\text { Ref. } 10\end{array}$ \\
\hline \multirow[t]{2}{*}{130662} & 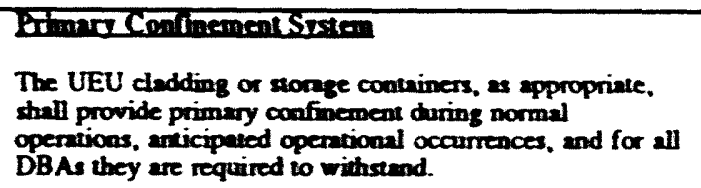 & c & $\begin{array}{l}\text { The EU-S tent provides confinement for all } \\
\text { postulated DBAs. }\end{array}$ & $\begin{array}{l}\text { Ref. } 1 \\
\text { Ref. } 10\end{array}$ \\
\hline & 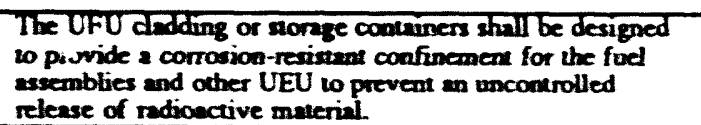 & $\mathrm{C}$ & $\begin{array}{l}\text { The EU-S trank is constructed o shiniess sted } \\
\text { for corrosion resistance }\end{array}$ & $\begin{array}{l}\text { Ref. } 10 \\
\text { Ref. } 10\end{array}$ \\
\hline
\end{tabular}




\begin{tabular}{|c|c|c|c|c|}
\hline $\begin{array}{l}\text { DOE } 6430.1 \mathrm{~A} \\
\text { Section }\end{array}$ & DOE 6430.1A Design Criterion & STATUS & Comment & Reference \\
\hline $\begin{array}{l}1540-99 \\
1540-99.0 \\
1540-99.0 .3\end{array}$ & 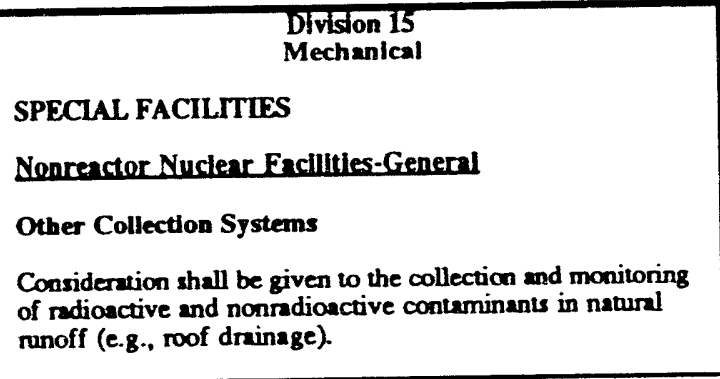 & C & $\begin{array}{l}\text { A curbed area is provided around the EU-S tank } \\
\text { to colled rinwwer runof. Colleted runoff is } \\
\text { processed by the general parpose evaporator. }\end{array}$ & $\begin{array}{l}\text { Ref. } 10 \\
\text { Ref. } 38\end{array}$ \\
\hline $1540-99.0 .6$ & $\begin{array}{l}\text { System Installation } \\
\text { The following design features represent recommended } \\
\text { practices for the installation of piping and valves carrying } \\
\text { hazardous process fluids. In addition, the dessign } \\
\text { professional shall consider the applicability of the criteria in } \\
\text { R. G. } 8.8 \text { for piping systems carrying radioactive materials. }\end{array}$ & c & 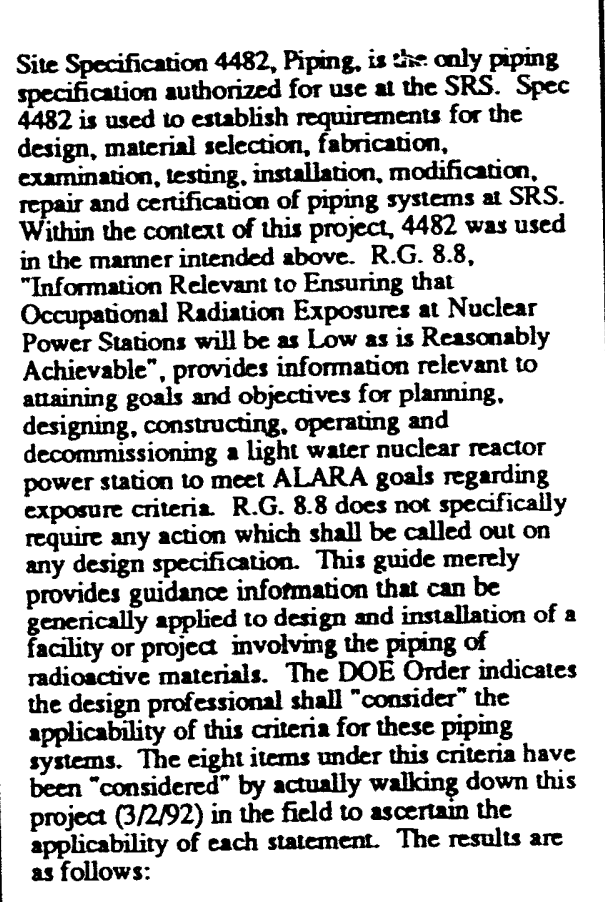 & Ref. 43 \\
\hline
\end{tabular}


EU-S Tank, DOE 6430.1A Design Compliance Review Page 39 of 52

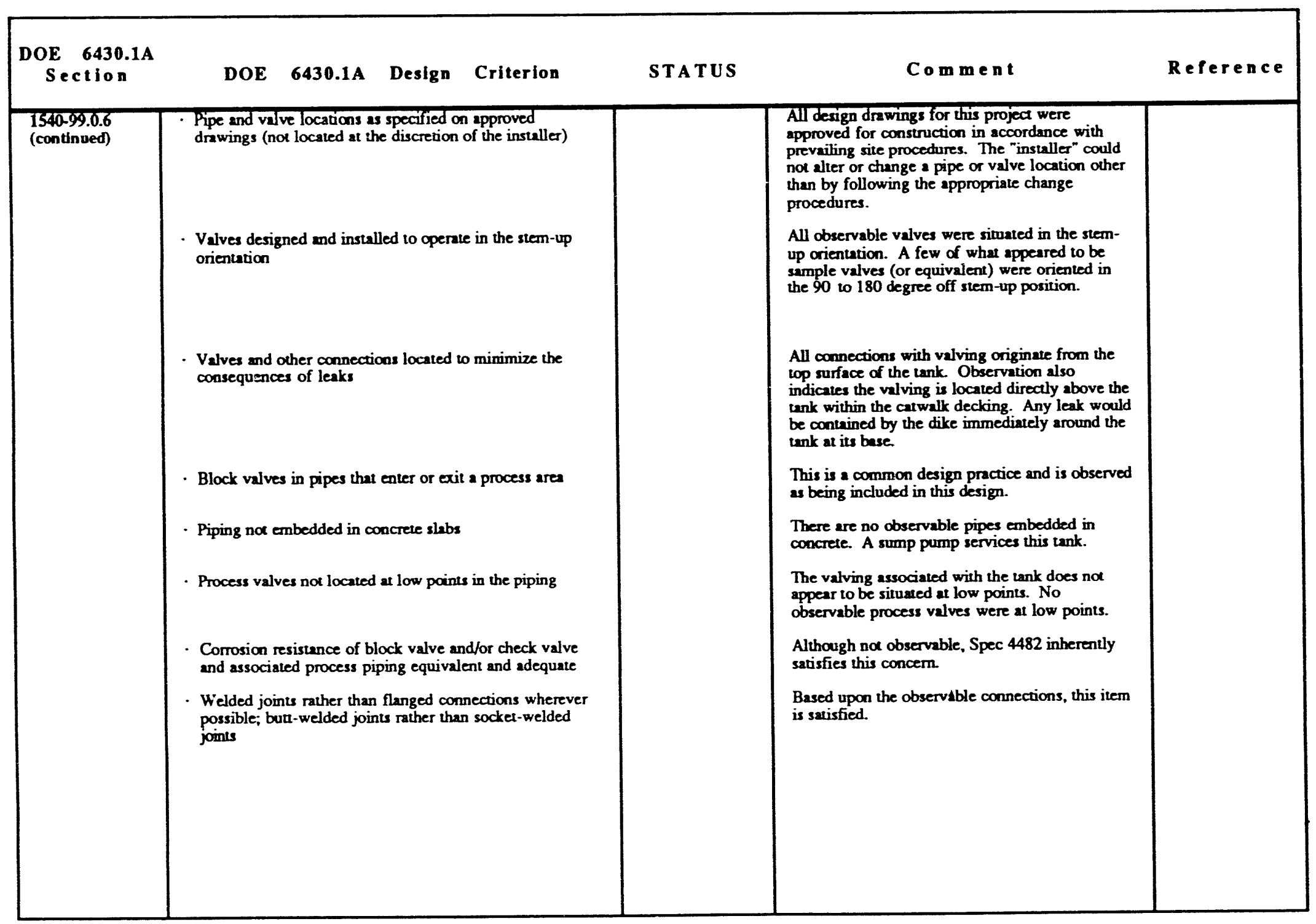


EU-S Tank, DOE 6430.1A Design Compliance Review

Page 40 of 52

\begin{tabular}{|c|c|c|c|c|}
\hline $\begin{array}{l}\text { DOE } 6430.1 A \\
\text { Section }\end{array}$ & DOE 6430.1A Design Criterion & STATUS & Comment & Reference \\
\hline $\begin{array}{l}1550 \\
1550-2 \\
1550-2.5 \\
1550-2.5 .5\end{array}$ & 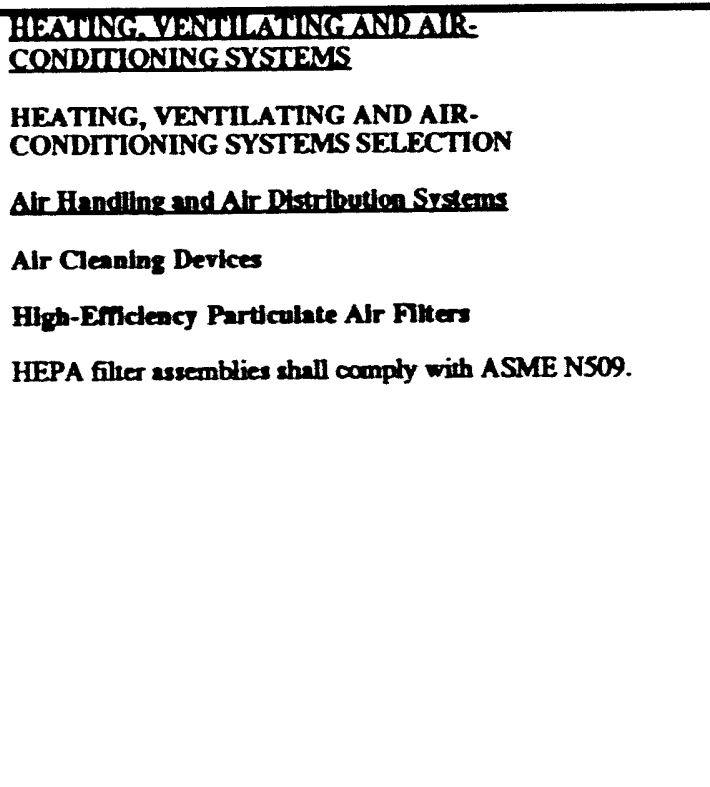 & C & 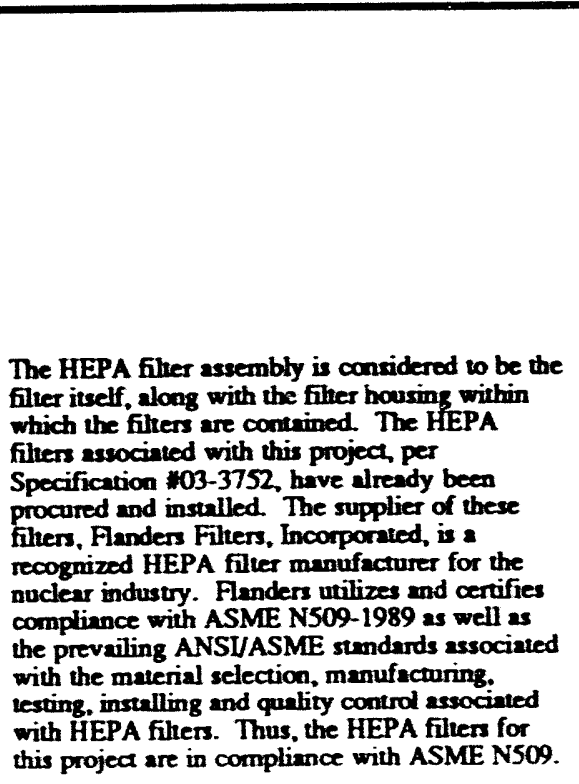 & Ref. 35 \\
\hline & $\begin{array}{l}\text { HEPA filtrarion system shall be used to minimize the release } \\
\text { of particulate contaminants such as carcinogens, infectious } \\
\text { agents, radioisotopes, or highly toxic materials when } \\
\text { determined by safety analysis to be necessary. }\end{array}$ & $C$ & $\begin{array}{l}\text { HEPA fitiers are used wo timit retease of } \\
\text { radionuclides. }\end{array}$ & $\begin{array}{l}\text { Rer. } 37 \\
\text { Ref. } 39\end{array}$ \\
\hline
\end{tabular}




\begin{tabular}{|c|c|c|c|c|}
\hline $\begin{array}{c}\text { DOE } 6430.1 \mathrm{~A} \\
\text { Section }\end{array}$ & DOE 6430.1A Design Criterion & STATUS & Comment & Reference \\
\hline $\begin{array}{l}1550-253 \\
\text { (continued) }\end{array}$ & 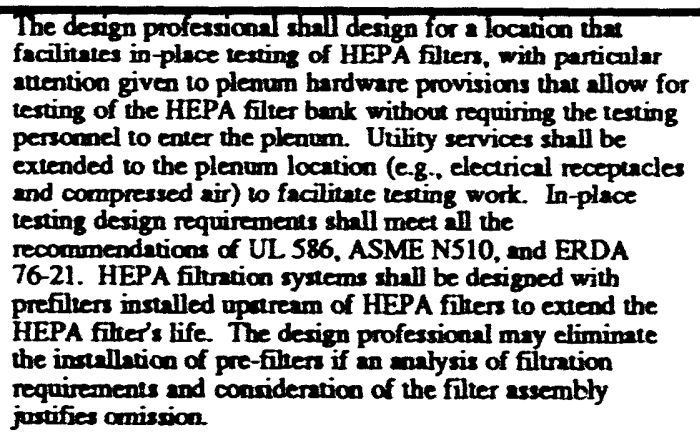 & $c$ & $\begin{array}{l}\text { The location of HiEPA titers facilintes in-place } \\
\text { vesting. Test ports are provided oo allow resting in } \\
\text { accordince with ASME } 510 \text { and ERDA 76-21. }\end{array}$ & Ref. 35 \\
\hline $\begin{array}{l}1589-99 \\
1589-99.0 \\
1589-99.0 .1\end{array}$ & 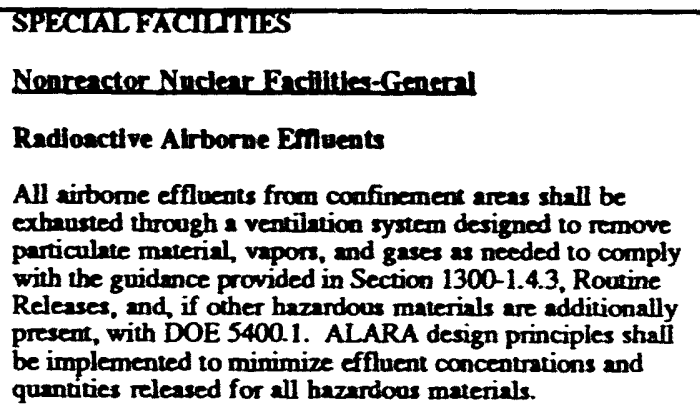 & C & $\begin{array}{l}\text { The limis of Section } 1300-1.4 .3 \text { are complied } \\
\text { with. ALARA design principles were } \\
\text { implemented in design of aiborne effluent } \\
\text { system. }\end{array}$ & $\begin{array}{l}\text { Ref. } 1 \\
\text { Ref. } 28\end{array}$ \\
\hline
\end{tabular}




\begin{tabular}{|c|c|c|c|c|}
\hline $\begin{array}{c}\text { DOE 6430.1A } \\
\text { Section }\end{array}$ & Design Criterion & STATUS & Comment & Reference \\
\hline $\begin{array}{l}\text { Ts:9-99.0.1 } \\
\text { (condnued) }\end{array}$ & 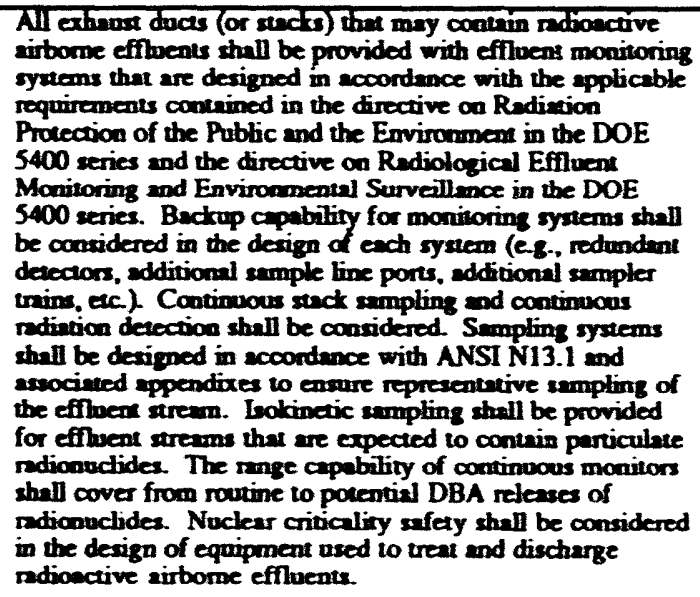 & C & 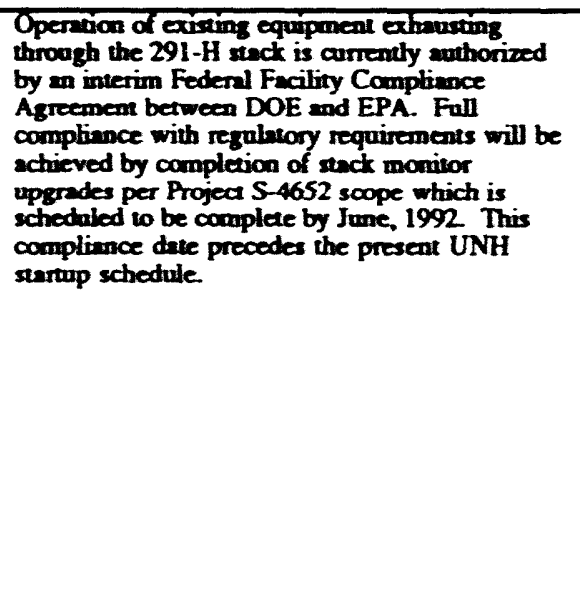 & Ret. 30 \\
\hline $\begin{array}{l}1605 \\
1605-1\end{array}$ & 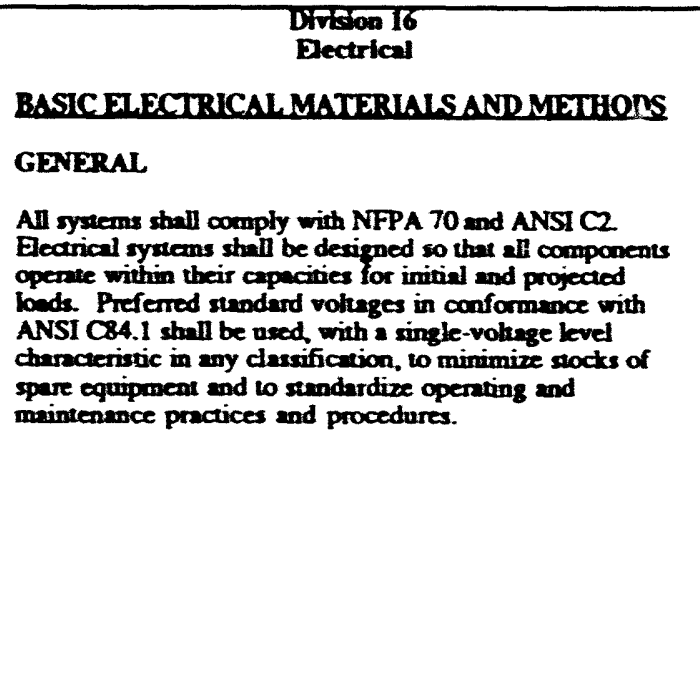 & C & 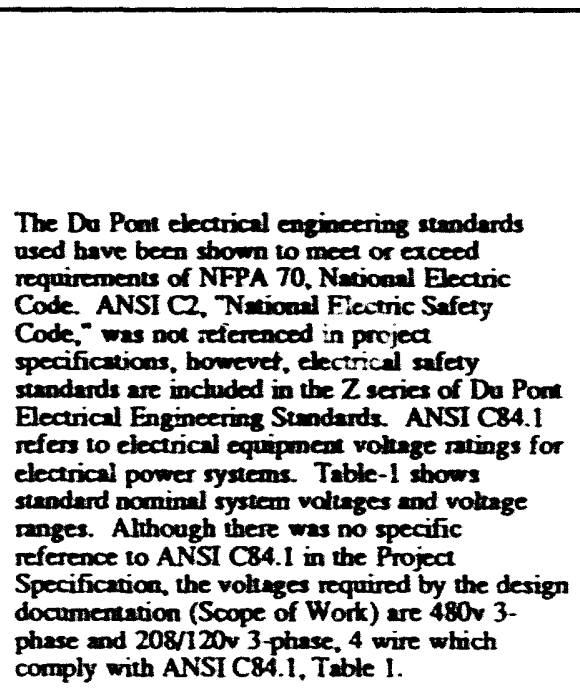 & Ref. 44 \\
\hline
\end{tabular}




\begin{tabular}{|c|c|c|c|c|}
\hline $\begin{array}{c}\text { DOE 6430.1A } \\
\text { Section }\end{array}$ & DOE 6430.1A Design Criterion & STATUS & Comment & Reference \\
\hline \multirow[t]{2}{*}{$\begin{array}{l}\text { TCOS-1 } \\
\text { (costinued) }\end{array}$} & 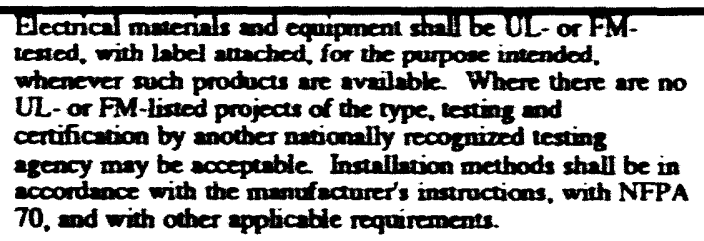 & $c$ & 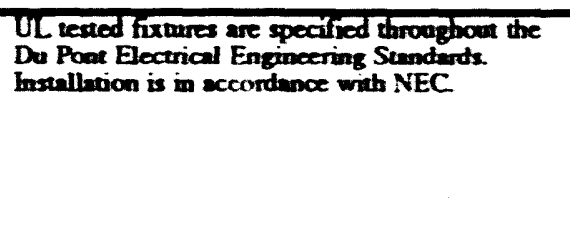 & Ref. 4 \\
\hline & 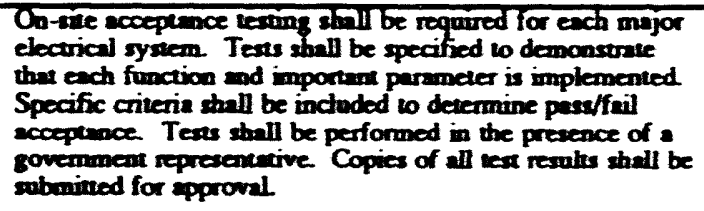 & C & 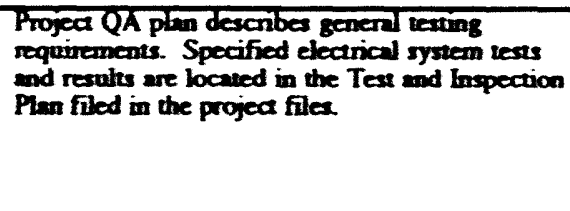 & $\begin{array}{l}\text { Ref. } 24 \\
\text { Ref. } 45\end{array}$ \\
\hline $\begin{array}{l}1605-2 \\
1 \cos -2.1 \\
1 \cos -2.1 .4\end{array}$ & 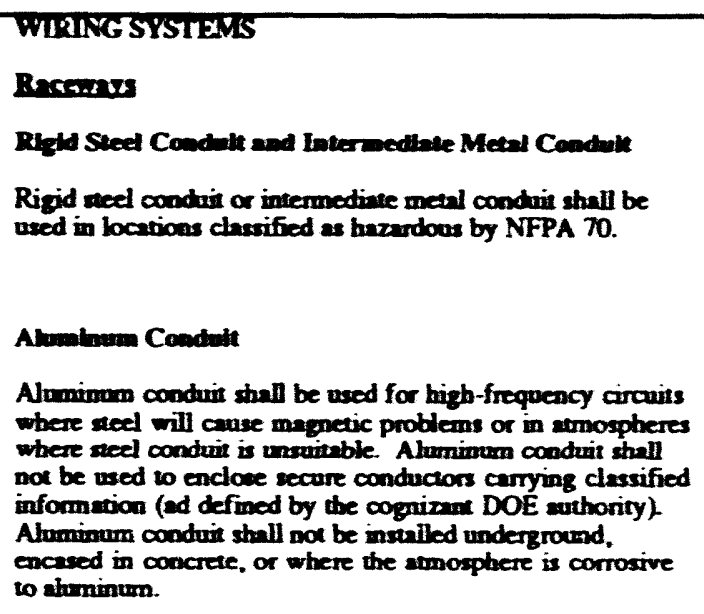 & C & 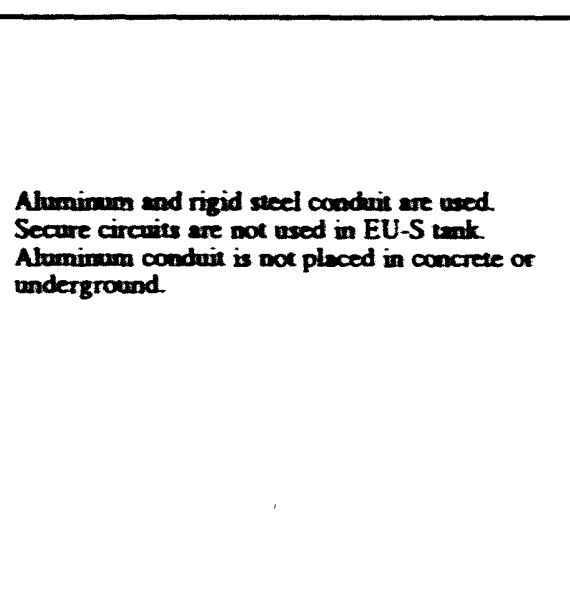 & $\begin{array}{l}\text { Ref. } 10 \\
\text { Ref. } 46\end{array}$ \\
\hline $\begin{array}{l}1605-22 \\
1605-22.1\end{array}$ & 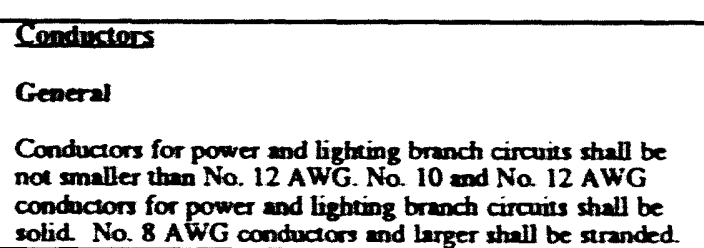 & c & $\begin{array}{l}\text { UERC scope of work specifies conductor sizes } \\
\text { to be used. }\end{array}$ & Ref. 37 \\
\hline
\end{tabular}




\begin{tabular}{|c|c|c|c|c|}
\hline $\begin{array}{l}\text { DOE 6430.1A } \\
\text { Section }\end{array}$ & DOE 6430.1A Design Criterion & STATUS & Commeat & Referense \\
\hline $\begin{array}{l}1605-22.1 \\
\text { (costined) }\end{array}$ & 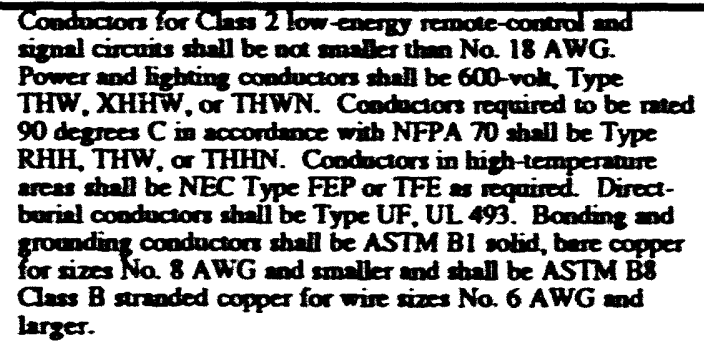 & c & 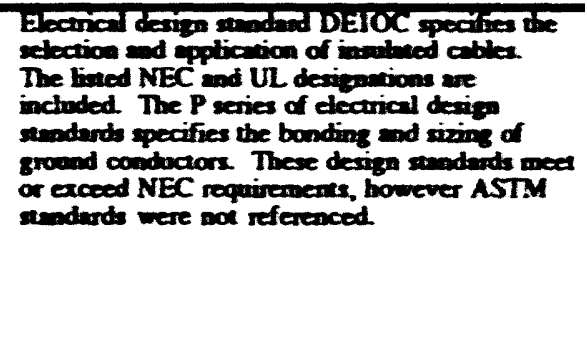 & Ref. 48 \\
\hline 16052223 & 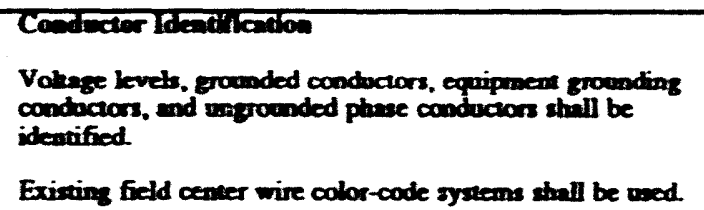 & c & 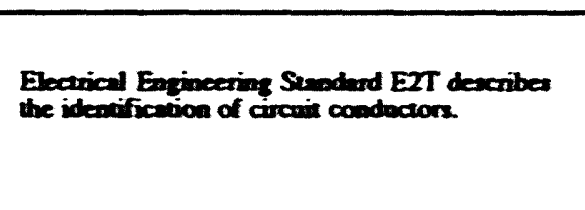 & $\begin{array}{l}\operatorname{Ref} \\
\operatorname{Ref}\end{array}$ \\
\hline T605-23 & $\begin{array}{l}\text { Recentindes } \\
\text { Reogpresdes stall comply with general grade as defimed in } \\
\text { FS W-C.596. }\end{array}$ & C & 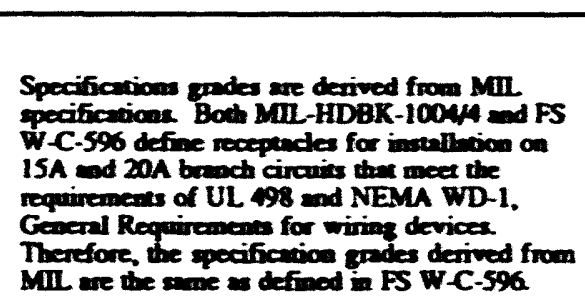 & Ref. 50 \\
\hline & 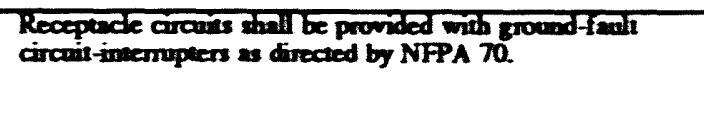 & C & 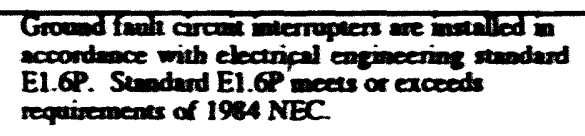 & Re. ST \\
\hline & 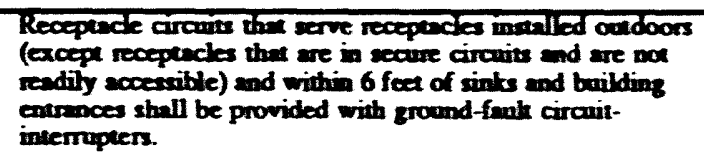 & $\mathrm{C}$ & 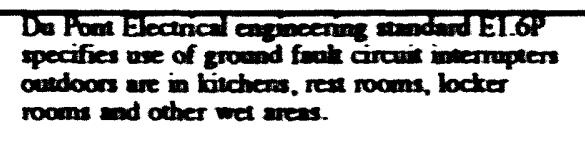 & RE. ST \\
\hline
\end{tabular}




\begin{tabular}{|c|c|c|c|c|}
\hline $\begin{array}{c}\text { DOE } 6430.1 A \\
\text { Section }\end{array}$ & DOE 6430.1A Desizn Criterion & STATUS & Comment & Reference \\
\hline $\begin{array}{l}1600 \\
16004 \\
1630-1.1\end{array}$ & 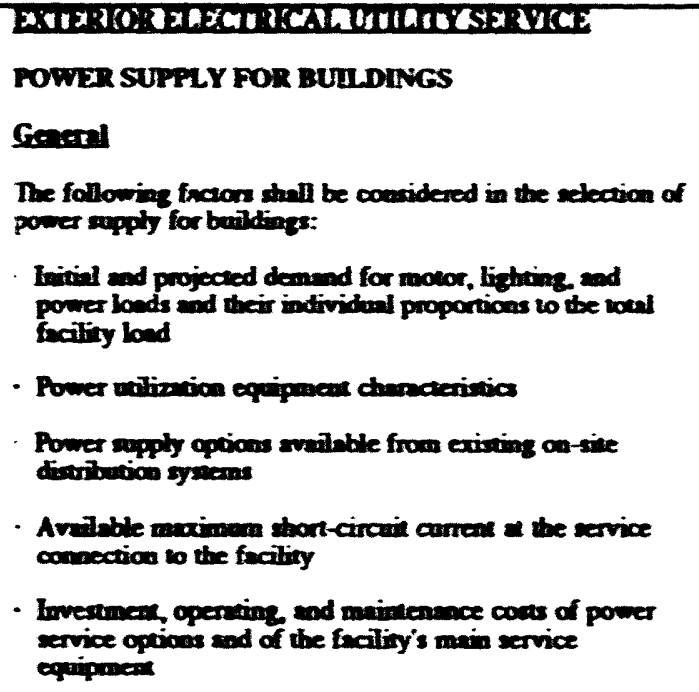 & c & 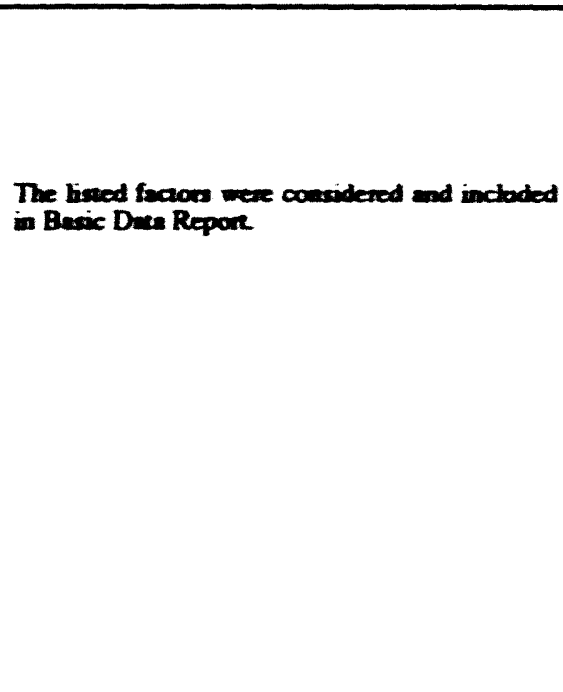 & Ref. 10 \\
\hline T6rota & 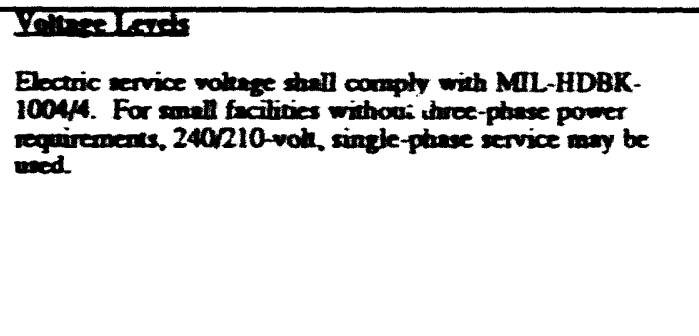 & C & 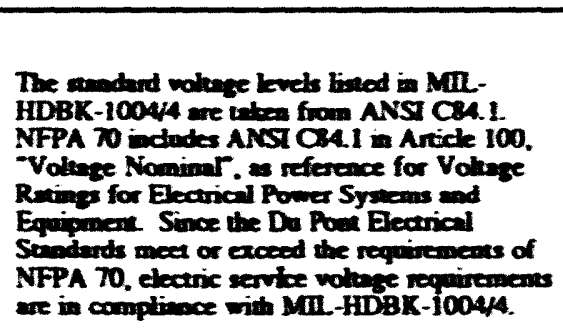 & \\
\hline Taro-5 & 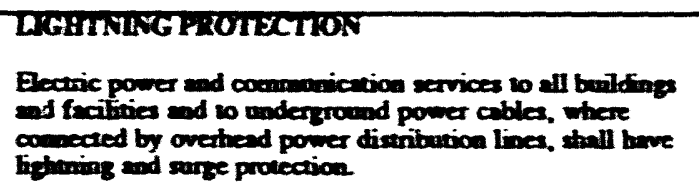 & C & Surge provection is provided for poner services. & Ref. 10 \\
\hline
\end{tabular}


EU-S Tank, DOE 6430.1A Design Compliance Review

Page 46 of 52

\begin{tabular}{|c|c|c|c|c|}
\hline $\begin{array}{l}\text { DOE 6430.1A } \\
\text { Section }\end{array}$ & DOR c430.1A Dester Criterion & STATUS & Coment & Reference \\
\hline $\begin{array}{l}\text { TES } \\
103,1\end{array}$ & 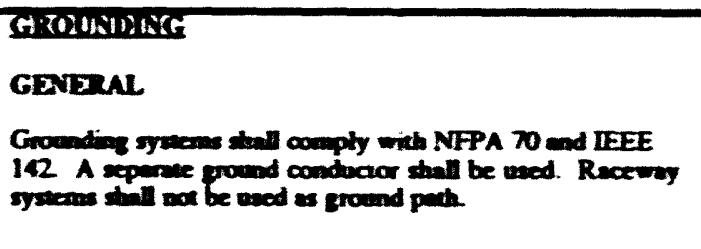 & c & 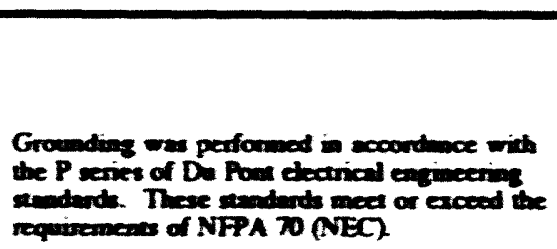 & $\begin{array}{l}\text { Ref } \\
\text { Ref. } 37\end{array}$ \\
\hline $\begin{array}{l}\text { TS5 } \\
16501\end{array}$ & 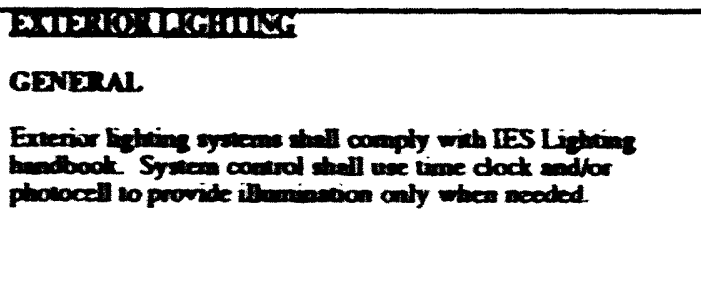 & c & 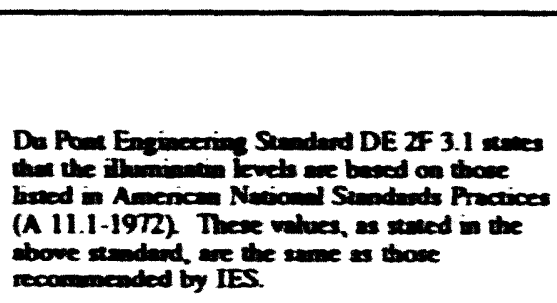 & $\begin{array}{l}\text { Ref } \$ 17 \\
\text { Ref } \Omega\end{array}$ \\
\hline $\begin{array}{l}10 a \\
16 a-1\end{array}$ & 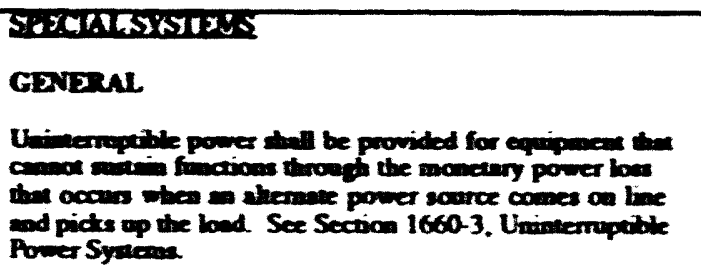 & c & Buncy bectup is provided for NMM circien. & Ret. I \\
\hline & 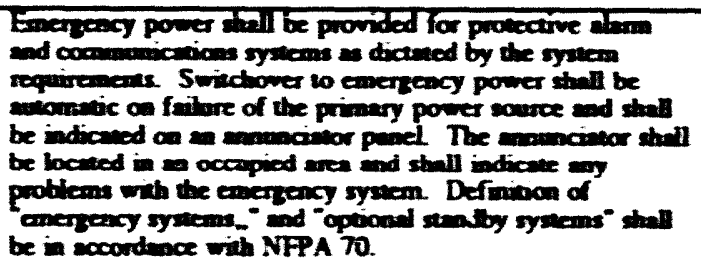 & $\mathbf{C}$ & 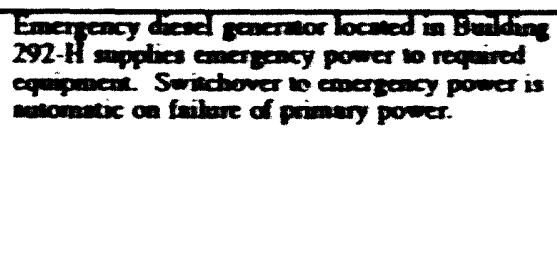 & Rers3 \\
\hline
\end{tabular}


EU-S Tank, DOE 6430.1 A Design Compliance Review Page 47 of 52

\begin{tabular}{|c|c|c|c|c|}
\hline $\begin{array}{l}\text { DOE 6430.1A } \\
\text { Section }\end{array}$ & DOE G30.1A Design Crüterion & STATUS & Cembent & Reference \\
\hline \multirow[t]{4}{*}{ 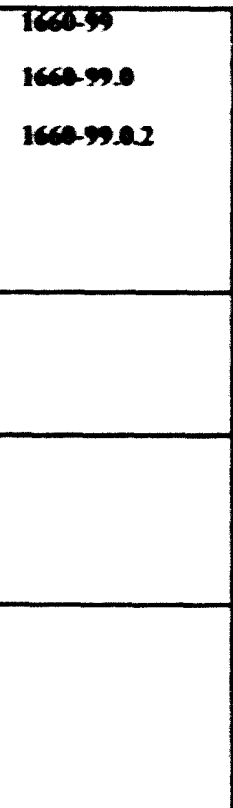 } & 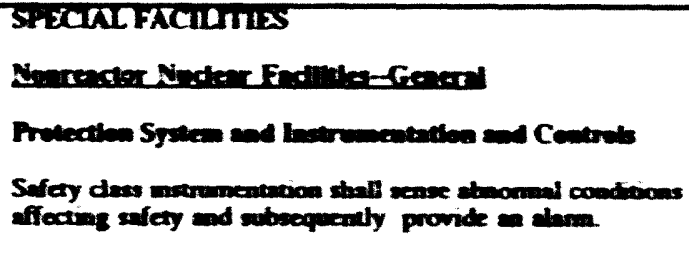 & c & 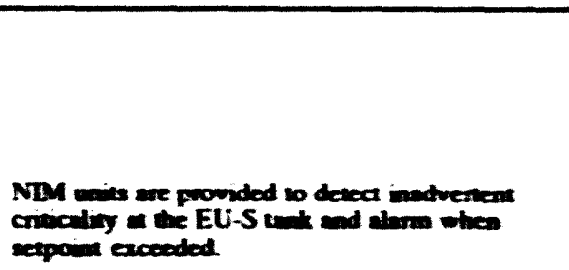 & Ret I \\
\hline & 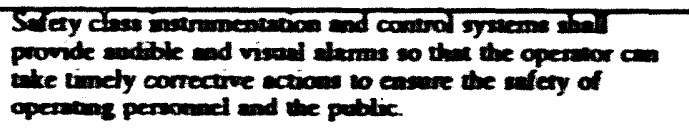 & $\tau$ & 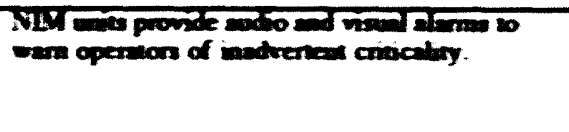 & रहT T \\
\hline & 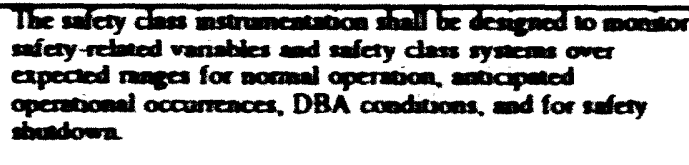 & $\mathrm{C}$ & 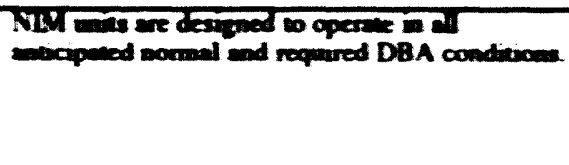 & Ref. 33 \\
\hline & 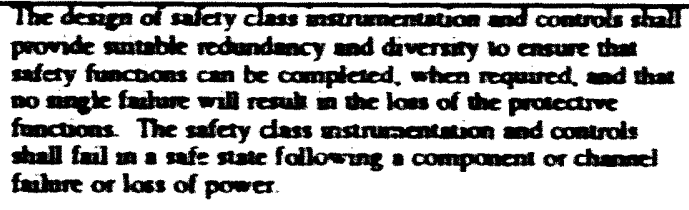 & C & 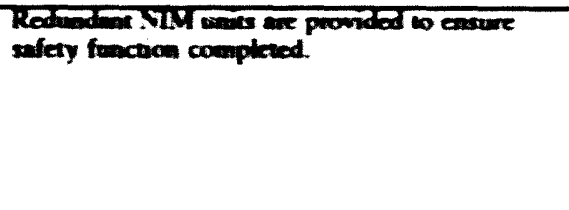 & ReT $T$ \\
\hline Tearshes & 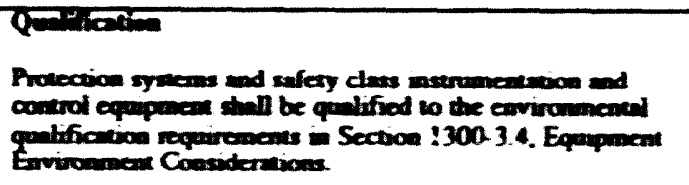 & c & 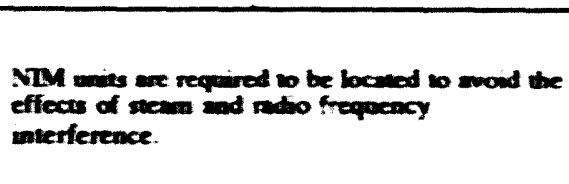 & $\begin{array}{l}\operatorname{Ref} 33 \\
\text { Ret }\end{array}$ \\
\hline Тब्बक्रम. & 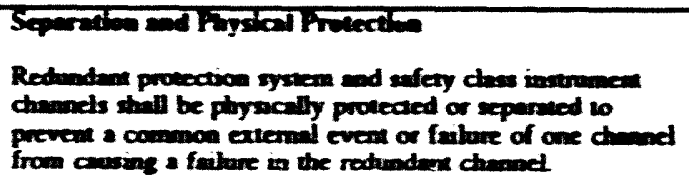 & c & 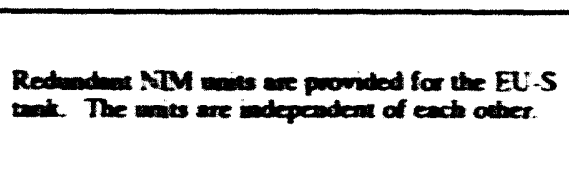 & Ref 1 \\
\hline
\end{tabular}




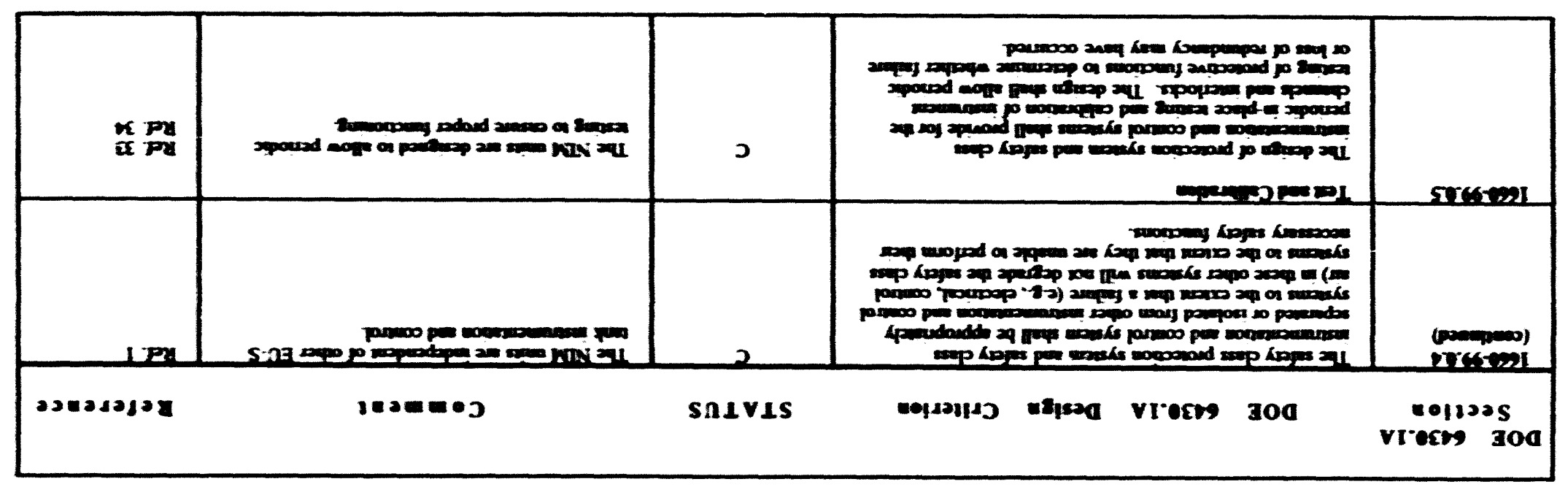

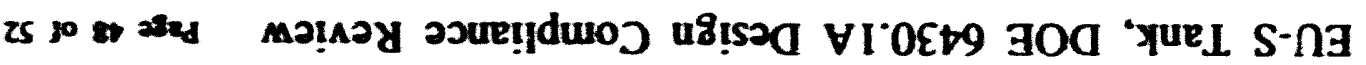




\section{RETERENCES}

1. Fisk, Patrlela L, and Durant, Wliliam S. Safaty Analyala-200 AraA

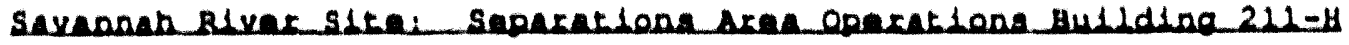
Qutadde racduldeda. Internal Report DPSTSA-200-11, Dor Reviow Draft, West Inghouse Savannah Rlvet Company, Savannah RIver S1te, April 1990.

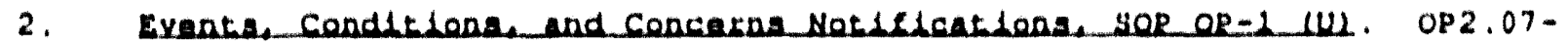
01. Rav. 2, Procedure Manual $\mathrm{St-1}$, Separations PMT, Westinghouse Savannah River Company, Alken, SC.

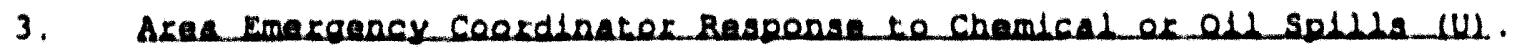
SOP 200-H-9561, Rev, 20, Procedure Manual 115-H, Weatinghouse savannah Alver Company, Alken, SC.

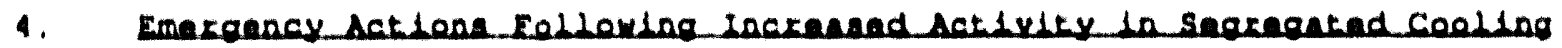
hatex. SOP 221-H-9406, Rev, 14, Procedure Manual ss5-5, Westinghouse Savannah River Company, Alken, SC.

5. Du Font englneering standards and standard Engineer Ing Speclelcat lons, Weat inghouge Savannah Rlver Company, Savannah River site, Alken, SC

6. Elca Hazarda Analyaja Separationa Area Operations. PLC Report $7, H$ Atoa, Rev. 0, E. I, du Pont de Nemoura c Company, Savannah River Plant, Alken, SC, April 7, 1988.

7. Llze Hazarda Anadysia. SE-DP-311, Rev. 1, Westinghouse Savannah River Company syotams Engineering Departmental procedures, savannah River slte, Alken, SC.

B. Smith, Winstion A. to Wright, S. R. Datermination ol whather or net

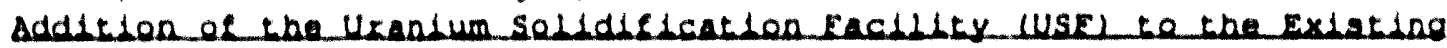

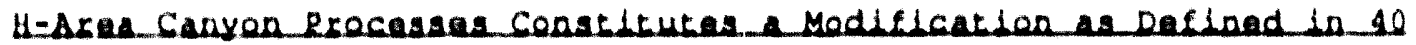
CER 61.26. United states Envitonmental Protection Agency, Reglon IV, At L. nta, GA, December 1, 1988.

9. Moyer, R. A. to Blgler, R, M. NERA Enydronmaotad Eyaduaclon. Urandum Solddilleation Eacidity. Project $\mathrm{S}-2052$. Inter-of 1 ce Memorandum, Savannah River Site, September $28,1988$.

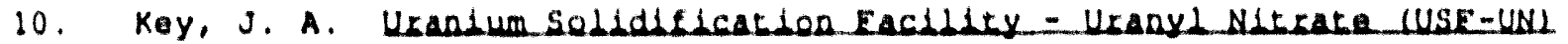
150. eee Gadien sterage Tank. 212-H. Basic Data Report 188-17, Rev. 2.

11. Speciflatiden 2-246020. Rev. 0, Savannah River Plant, Project S-4257, October 10,1988 .

12. Daslon Rrocass Hazards Raylaw Report. USF-UN 150,000 Gallon Storage Tank, UE6C/SCD Profect No, 8244.505, Du Pont Project No. 954257, Rav. 0 , March 7, 1989 . 


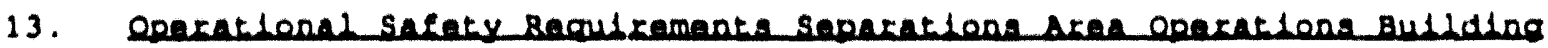

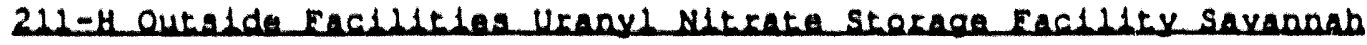
Blyer Slte. WSRC-RP-90-568, DOE Final Review Draft, Westinghouse Savannah RJvar Company, Savannah River Site, September 1991.

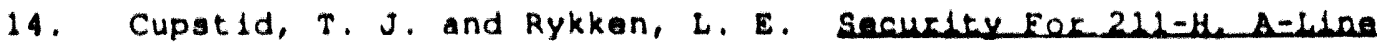
Eacilitiea. EPD-NSP-901022, March 12, 1990.

15. Rrocass Hararde Baylax. PHR-H-437, Uranium Solidification Facility, Savannah Rlver Plant, Alken, SC, September 1988

16. Rre-operat Lonal erocess Hazards Revlem. WSRC PH-90-104, West Inghouse Savannah River Company, Aiken, SC.

17. Materdal centred and Acaeuntablulty elan. 150,000 Gallon storage Tank, Savannah Rlver Site, Alken, SC, July 1990.

18. Induatelad Hraiane. DPSOP 40-5, Rev. 3, Savannah Rivar Plant, Aiken, sC, July 1990 .

19. Emoleyee Satatiy Manuad (UU). Procedure Manual Bo, Rev, 0 , West Inghouse Savannah River Company, Savannah River Slte, Aiken, SC, April 1. 1991 .

20. Sterage Tank Desdan Drawinga, BPF 21027, Sheets 1-60, Savannah River Site, Aiken, SC.

21. Smith, Harold, M. to Lowe, Mike. Struatived Review of hiquld Urany Nibrate raak. Department of the Army, Charleston, SC, June 27, 1989.

22. Catoe, R. J. to Blanco, S. Elpal Repert en the Ucanium Solidification Eacidity Nitrate Tank. Department of the Army, Jackson, SC, January 23. 1989.

23. Savanoah River Ouablty Asaurance Rlan, DPSPM-SITE-1, Savannah River Plant, Aiken, SC, March 4, 1987.

24. USE Preject Ouadity Assurance Plan. Project 52052, Uranium Solldiflcation Facility, Savannah River Plant, Aiken, SC, December 14, 1988 .

25. Bepert of Subsurface Seld cendithens for Storage Tuak Site. Meuser Rut ledge Consulting Engineers, NY, December 6, 1988.

26. Mayson, W. P. to Key, J. A. Inspaction Repertis for contrelled Backfid. Savannah River Plant Project 4257, UNH Storage Tank, Ebasco Services Incorporated, Savannah River Plant, Aiken, SC, March 24, 1989

27. Mayson, W. P. to Gentry, S. E. Eoundation Exaavation. Savannah River Plant Project 4257, UNH 150,000 Galion Storage Tank, Savannah River Plant, Alken, SC, January $30,1989$. 
28. Rideout, S. P. to Selfo, E. A. and Low, J. M. Seurce Tarma fer Eavironmental Releases from the Urantum Soldedification Eacidity. Rrotect $s-2052$. DPST-88-822, September 9,1988 .

29. Badielegiaal centrels WU. Procedure Manual 50, Rev. 1. Westinghouse Savannah River Company, Savannah River Site, Aiken, SC, August 2, 1991.

30. HArea canyon Exhaust Particulate Sameling. Project S4652. Westinghouse Savannah River Company, Savannah River Site, Aiken, SC.

31. Nenreacter Nuclear Facilities: Standards and Crtterta Gulde . DOE/TIC11603, Rev. 1, United States Department of Energy, September, 1986.

32. Low, J. M. to Cowen, M. L. Methodology Used Te Determine Safety Clase Ltems For the Urantum Solidification Fachlity (USF) (U). WSRC-RP-89441, Westinghouse Savannah River Company, A1ken, SC, July 10, 1989.

33. Eleld Instaldation of Nuclear Incident Monitor (NIM). Site Specification 9765 , Rev. 0, Savannah River Plant, Aiken, SC, October 19. 1989.

34. Techolcal Manual - Nuclear Locident Alorm System. DPSTM-NIM, Westinghouse Savannah River Company, Savannah River Site, Alken, SC, December 1989 .

35. Elters Hiah Efflalency Rarticulate Alr (HEPA) Equipment Specification. Specification 44505-2800-2802, Rev. 2, Savannah River Plant Profect 9S4257, Savannah River Plant, Alken, SC, August 1, 1989.

36. Determination of Nuclear crit ladity Hazard in UNH Interim storage Tank System. WSRC-TR-90-126, Westinghouse Savannah River Company, Savannah River Site, Aiken, SC, March 27, 1990.

37. Scepes of Work. USF/UNH 150,000 Gallon Storage Tank, File No. 8244.505-44, Document I.D. 505L044, United Engineers and Constructors, Philadelphia, PA, October 17, 1989.

38. 150,000 Gadlon Sterage Tank Rarp Precess Precess and Instruments. W840219, Rev. 54, Savannah River Plant, Alken, SC.

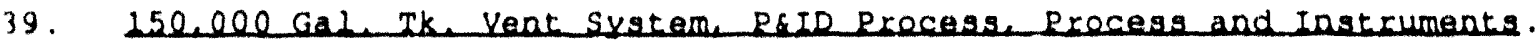
W840220, Rev. 16, Savannah River Plant, Aiken, SC.

40. Cadibration of the 150,000 Gadion Tank - Comoarigon of BUSKA and Besemont Liquid Level Measurements. ESH-MCP-900093, Westinghouse Savannah River Company, Savannah Ri\%er Site, Aiken, SC, December 7 , 1990.

41. Uranyl Nitrate Sterage Tank (EU-S) Eacidity Startup P Lan (UI). NMPSUF-910015, Rev. 1, Westinghouse Savannah River Company, Savannah River Site, Aiken, SC, September 30, 1991. 
42. General Purpese Evaporater - Processing Waste From Tank 716 . DPSOL 231-H-4065, Rev. 13, Westinghouse Savannah River Company, Savannah River Site, Aiken, SC.

43. Rrecess and Service Piping. Site Specification No. 4482, E. I. du Pont de Nemours \& Co., Inc., Savannah River Plant, Aiken, SC.

44. Du Pont Electrical Engineering Standards. Westinghouse Savannah River Company, Savannah River Site, Aiken, SC.

45. USE UN Sterage Tank. Project 9S4257, Westinghouse Savannah River Company, Savannah River Site, Aiken, SC.

46. 15e, 000 Gallen Sterage Tank, General Legend, Electrical. W845028, Rev. 4, Savannah River Plant, Aiken, SC.

47. Du Pont Electrical Design Standards. Westinghouse Savannah River Company, Savannah River Site, Aiken, SC.

48. Insulated Electrical Cables, Selection and Application. Electrical Design Standard DE1OC, Westinghouse Savannah River Company, Savannah River Site, Aiken, SC, August 1984 .

49. Identification of circuit conducters. Electrical Engineering Standard E2T, Westinghouse Savannah River Company, Savannah River Site, Aiken, SC, August 1984 .

50. Beceptacles and Plugs on Sites Established After 1965. Electrical Engineering Standard E1.2N, Westinghouse Savannah River Company, Savannah River Site, Aiken, SC, November 1987.

51. Siround-Fault circuit Interrupters. Electrical Engineering Standard E1.6P, Westinghouse Savannah River Company, Savannah River Site, Aiken, SC, October 1984 .

52. 150,000 Gallon UNH Sterage Tank, Ifighting Electrical. W835359, Rev. 2, Savannah River Plant, Aiken, SC.

53. 15? 000 Gallen UNH Sterage Tank Rower Plan te Fan Heuse, Electrical. W8(6055, Rev. 15, Savannah River Plant, Aiken, SC. 

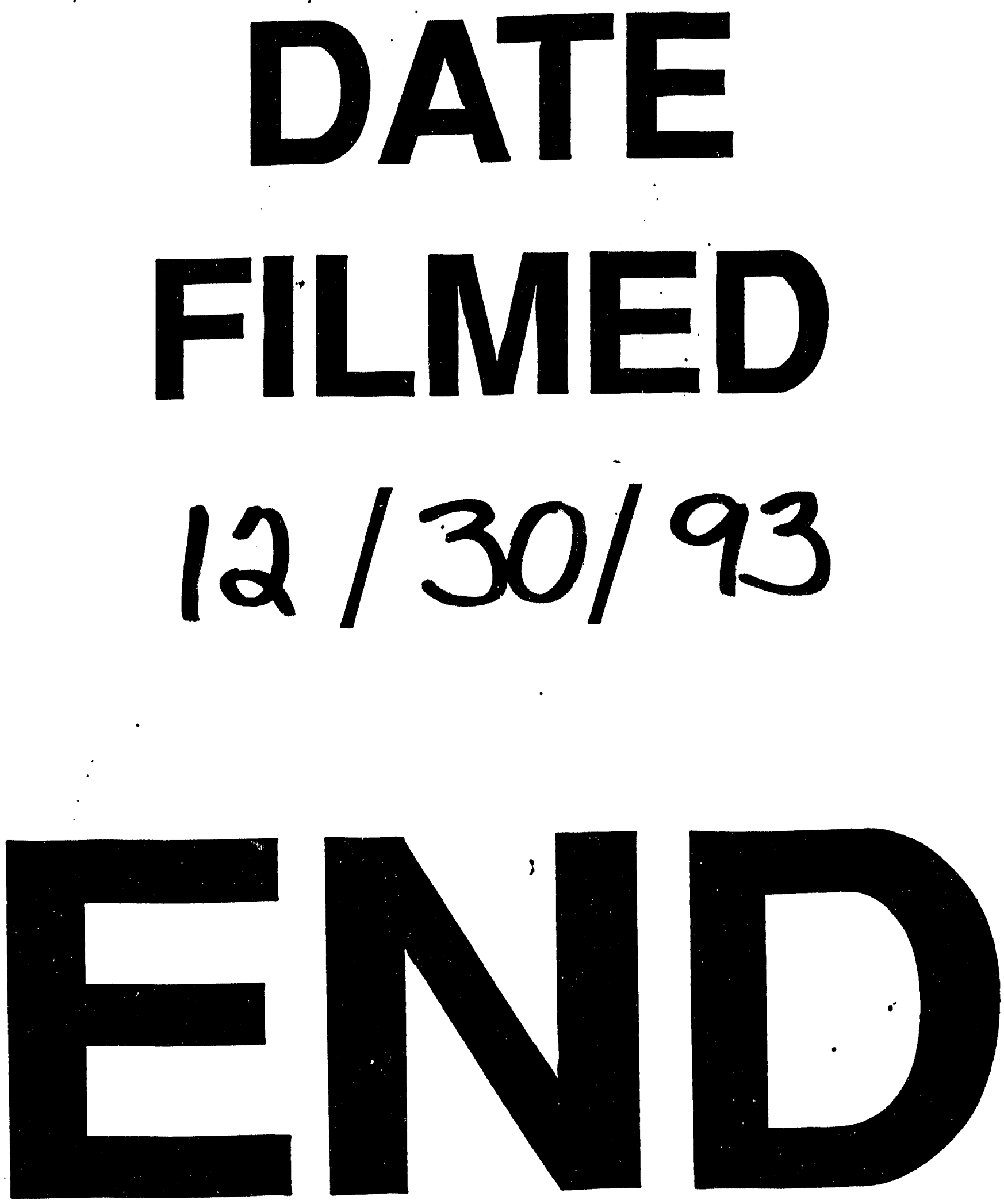
